Nevada

Environmental

Restoration

Project

\title{
Corrective Action Investigation Plan for Corrective Action Unit 556: Dry Wells and Surface Release Points Nevada Test Site, Nevada
}

Controlled Copy No.:

Revision No.: 0

February 2007

Approved for public release; further dissemination unlimited.

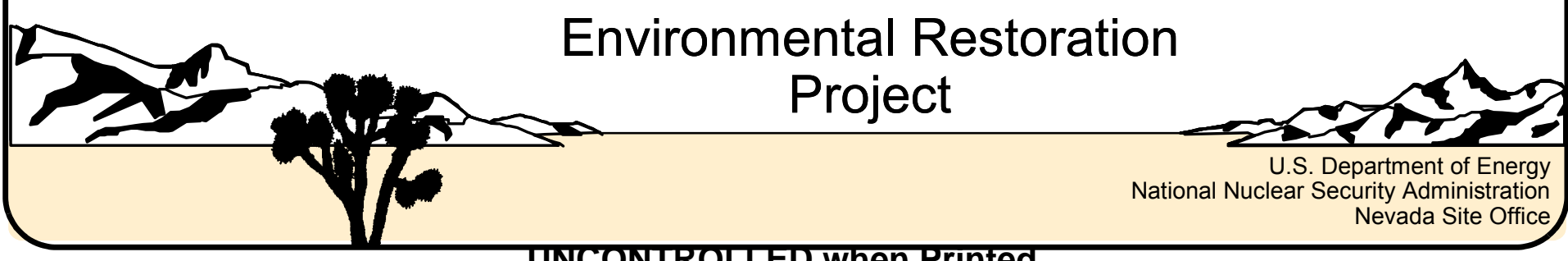


Available for sale to the public from:

U.S. Department of Commerce

National Technical Information Service

5285 Port Royal Road

Springfield, VA 22161

Phone: 800.553 .6847

Fax: 703.605.6900

Email: orders@ntis.gov

Online ordering: http://www.ntis.gov/ordering.htm

Available electronically at http://www.osti.gov/bridge

Available for a processing fee to U.S. Department of Energy and its contractors, in paper, from:

U.S. Department of Energy

Office of Scientific and Technical Information

P.O. Box 62

Oak Ridge, TN 37831-0062

Phone: 865.576.8401

Fax: 865.576.5728

Email: reports@adonis.osti.gov

Reference herein to any specific commercial product, process, or service by trade name, trademark, manufacturer, or otherwise, does not necessarily constitute or imply its endorsement, recommendation, or favoring by the United States Government or any agency thereof or its contractors or subcontractors. 


\title{
CORRECTIVE ACTION INVESTIGATION PLAN FOR CORRECTIVE ACTION UNIT 556: DRY WELLS AND SURFACE RELEASE POINTS NEVADA TEST SITE, NEVADA
}

\author{
U.S. Department of Energy \\ National Nuclear Security Administration \\ Nevada Site Office \\ Las Vegas, Nevada
}

Controlled Copy No.:

Revision No.: 0

February 2007

Approved for public release; further dissemination unlimited. 


\section{CORRECTIVE ACTION INVESTIGATION PLAN FOR CORRECTIVE ACTION UNIT 556: DRY WELLS AND SURFACE RELEASE POINTS NEVADA TEST SITE, NEVADA}

Approved by: APPROVED SIGNATURE

Date: 02/15/2007

Peter A. Sanders

Acting Federal Sub-Project Director

Industrial Sites Sub-Project

Approved by: APPROVED SIGNATURE

Date: $\underline{02 / 15 / 2007}$

Kevin J. Cabble

Acting Federal Project Director

Environmental Restoration Project 


\section{Table of Contents}

List of Figures. . . . . . . . . . . . . . . . . . . . .

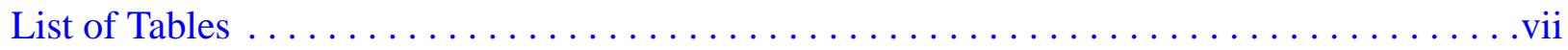

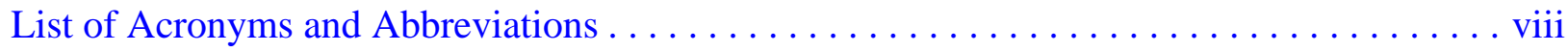

Executive Summary . . . . . . . . . . . . . . . . . . . . . . ES-1

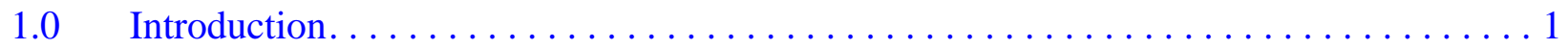

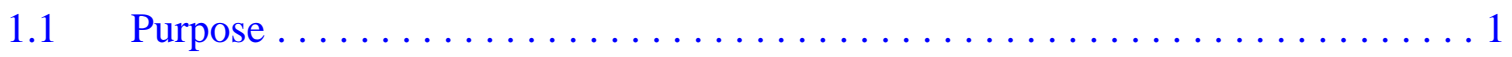

1.1.1 Corrective Action Unit 556 History and Description. . . . . . . . . . . 3

1.1.2 Data Quality Objective Summary ................... 3

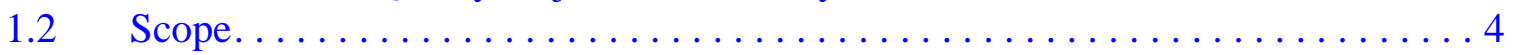

1.3 Corrective Action Investigation Plan Contents $\ldots \ldots \ldots \ldots \ldots \ldots \ldots$

$2.0 \quad$ Facility Description. . . . . . . . . . . . . . . . . 6

2.1 Physical Setting. . . . . . . . . . . . . . . . . . . . . 6

2.1 .1 Yucca Flat. . . . . . . . . . . . . . . . . . . . . . 6

$2.1 .2 \quad$ Jackass Flats . . . . . . . . . . . . . . . . . . 7

2.2 Operational History. . . . . . . . . . . . . . . . . . . . . . . 7

2.2.1 Corrective Action Site 06-20-04, National Cementers Dry Well. . . . . . 7

2.2.2 Corrective Action Site 06-99-09, Birdwell Test Hole . . . . . . . . . . . . . 8

2.2.3 Corrective Action Site 25-60-03, E-MAD Stormwater Discharge and Piping ....................... 9

2.2.4 Corrective Action Site 25-64-01, Vehicle Washdown and

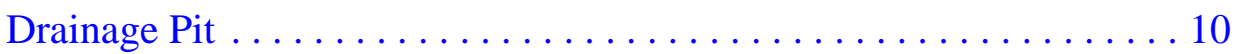

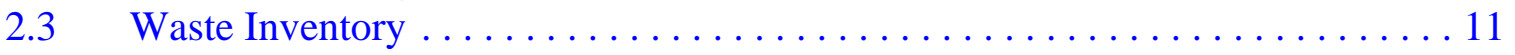

2.3.1 Corrective Action Site 06-20-04, National Cementers Dry Well. . . . . . 11

2.3.2 Corrective Action Site 06-99-09, Birdwell Test Hole . . . . . . . . . . . . . 11

2.3.3 Corrective Action Site 25-60-03, E-MAD Stormwater Discharge and Piping ..................... 11

2.3.4 Corrective Action Site 25-64-01, Vehicle Washdown

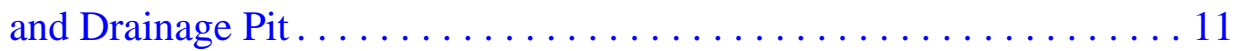

$2.4 \quad$ Release Information . . . . . . . . . . . . . . . . . . . . 12

2.4.1 Corrective Action Site 06-20-04, National Cementers Dry Well. . . . . . 12

2.4.2 Corrective Action Site 06-99-09, Birdwell Test Hole . . . . . . . . . . . . 12

2.4.3 Corrective Action Site 25-60-03, E-MAD Stormwater Discharge and Piping ..................... 13

2.4.4 Corrective Action Site 25-64-01, Vehicle Washdown and

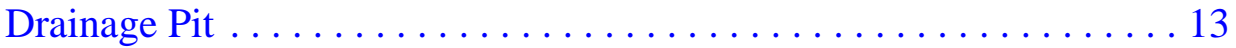

2.5 Investigative Background . . . . . . . . . . . . . . . . . 14

2.5.1 Corrective Action Site 06-20-04, National Cementers Dry Well. . . . . 14 


\section{Table of Contents (Continued)}

2.5.2 Corrective Action Site 06-99-09, Birdwell Test Hole .............. 14

2.5.3 Corrective Action Site 25-60-03, E-MAD Stormwater Discharge and Piping ........................... 14

2.5.4 Corrective Action Site 25-64-01, Vehicle Washdown and Drainage Pit............................... 15

2.5.5 National Environmental Policy Act ................... 16

$3.0 \quad$ Objectives ................................... 17

$3.1 \quad$ Conceptual Site Model ............................... 17

3.1.1 Land Use and Exposure Scenarios .................... 22

3.1.2 Contaminant Sources .......................... 22

3.1.3 Release Mechanisms ........................ 22

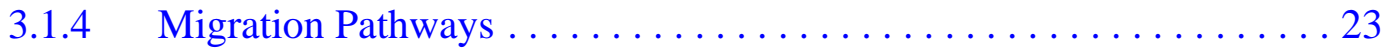

3.1.5 Exposure Points ............................... 24

3.1.6 Exposure Routes............................. 24

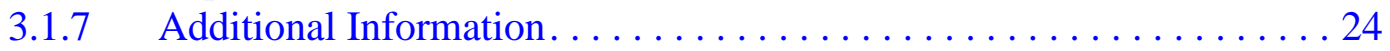

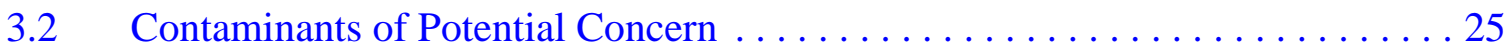

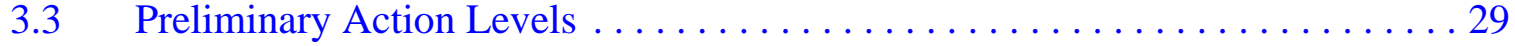

3.3.1 Chemical PALs.............................. 31

3.3.2 Total Petroleum Hydrocarbon PALs $\ldots \ldots \ldots \ldots \ldots \ldots \ldots \ldots \ldots$

3.3.3 Radionuclide PALs.......................... 32

$3.4 \quad$ Data Quality Objective Process Discussion ...................... 32

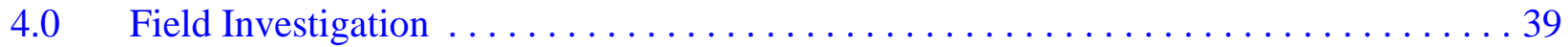

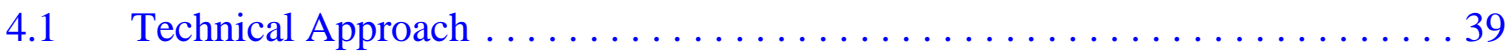

$4.2 \quad$ Field Activities . ...................................... 39

4.2.1 Site Preparation Activities . . . . . . . . . . . . . . . . . . 40

4.2.2 Sample Location Selection........................ 40

4.2.3 Sample Collection ........................... 41

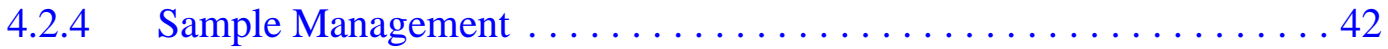

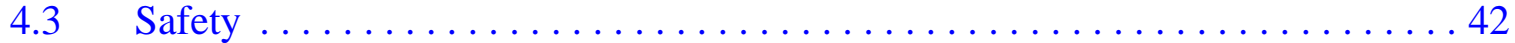

$4.4 \quad$ Site Restoration. . . . . . . . . . . . . . . . . . . . . . . . . . . . 43

$5.0 \quad$ Waste Management. .................................... 44

$5.1 \quad$ Waste Minimization $\ldots \ldots \ldots \ldots \ldots \ldots \ldots \ldots \ldots \ldots \ldots \ldots \ldots \ldots, \ldots \ldots$

$5.2 \quad$ Potential Waste Streams . . . . . . . . . . . . . . . . . . . . . . 45

$5.3 \quad$ Investigation-Derived Waste Management $\ldots \ldots \ldots \ldots \ldots \ldots \ldots \ldots \ldots$

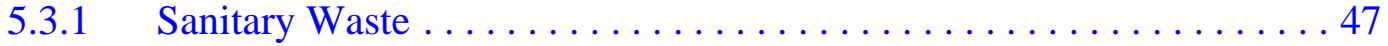

5.3.2 Low-Level Radioactive Waste...................... 47

5.3 .3 Hazardous Waste ........................... 48

5.3 .4 Hydrocarbon Waste $\ldots \ldots \ldots \ldots \ldots \ldots \ldots \ldots \ldots \ldots \ldots$ 


\section{Table of Contents (Continued)}

5.3.5 Mixed Low-Level Waste . . . . . . . . . . . . . . . . . . 49

5.3.6 Polychlorinated Biphenyls .......................... 49

$5.4 \quad$ Management of Specific Waste Streams . . . . . . . . . . . . . . . . 50

$5.4 .1 \quad$ Personal Protective Equipment. ................... 50

5.4.2 Management of Decontamination Rinsate................ 50

5.4 .3 Management of Soil ........................... 51

5.4 .4 Management of Debris ........................... 51

5.4 .5 Field-Screening Waste . . . . . . . . . . . . . . . . . . 52

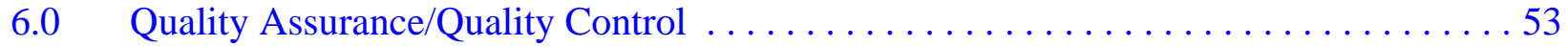

6.1 Quality Control Sampling Activities $\ldots \ldots \ldots \ldots \ldots \ldots \ldots \ldots \ldots \ldots \ldots$

$6.2 \quad$ Laboratory/Analytical Quality Assurance .................... 54

6.2.1 Data Validation.............................. 54

6.2.2 Data Quality Indicators........................... 54

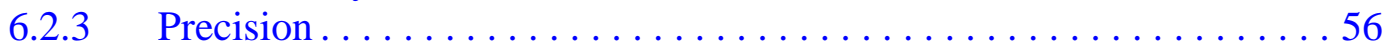

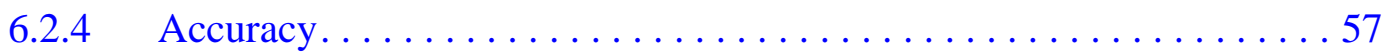

$6.2 .5 \quad$ Representativeness ........................... 58

6.2.6 Completeness ............................... 58

$6.2 .7 \quad$ Comparability ................................. 59

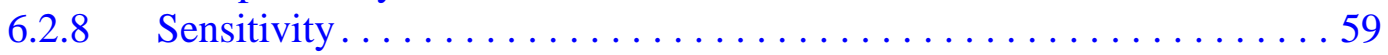

$7.0 \quad$ Duration and Records Availability ............................ 60

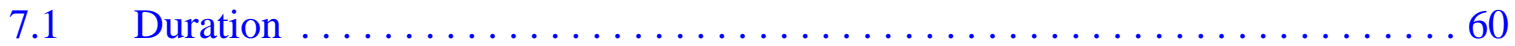

$7.2 \quad$ Records Availability ................................. 60

$8.0 \quad$ References........................................... 61

\section{Appendix A - Data Quality Objectives}

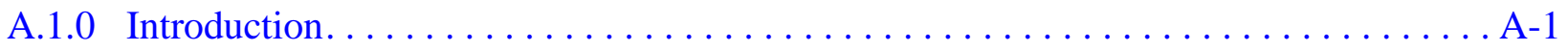

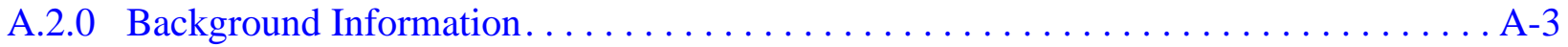

A.2.1 Corrective Action Site 06-20-04, National Cementers Dry Well. . . . . . . . . . A-3

A.2.2 Corrective Action Site 06-99-09, Birdwell Test Hole . . . . . . . . . . . . . . A-6

A.2.3 Corrective Action Site 25-60-03, E-MAD Stormwater

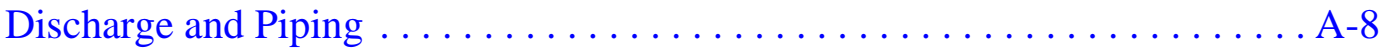

A.2.4 Corrective Action Site 25-64-01, Vehicle Washdown and Drainage Pit . . . . A-10

A.3.0 Step 1 - State the Problem................................ A-13

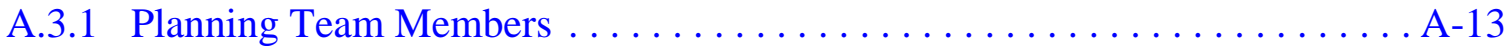

A.3.2 Conceptual Site Model . .......................... A-13 


\section{Table of Contents (Continued)}

A.3.2.1 Contaminant Release ........................... A-15

A.3.2.2 Potential Contaminants.......................... A-23

A.3.2.3 Contaminant Characteristics..................... A-25

A.3.2.4 Site Characteristics........................ A-25

A.3.2.5 Migration Pathways and Transport Mechanisms............. A-25

A.3.2.6 Exposure Scenarios ........................ A-26

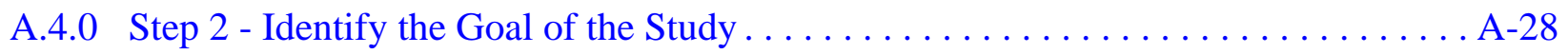

A.4.1 Decision Statements . ............................. A-28

A.4.2 Alternative Actions to the Decisions ...................... A-29

A.4.2.1 Alternative Actions to Decision I. . . . . . . . . . . . . . . A-29

A.4.2.2 Alternative Actions to Decision II . . . . . . . . . . . . A-29

A.5.0 Step 3 - Identify Information Inputs . . . . . . . . . . . . . . . . . . A-30

A.5.1 Information Needs . . . . . . . . . . . . . . . . . . . . . . . . A-30

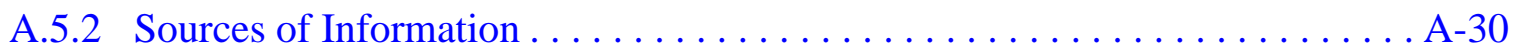

A.5.2.1 Sample Locations ........................... A-31

A.5.2.2 Analytical Methods ......................... A-33

A.6.0 Step 4 - Define the Boundaries of the Study $\ldots \ldots \ldots \ldots \ldots \ldots \ldots \ldots \ldots$ A-34

A.6.1 Target Populations of Interest. . . . . . . . . . . . . . . . . . . A-34

A.6.2 Spatial Boundaries .................................. A-34

A.6.3 Practical Constraints . ............................. A-34

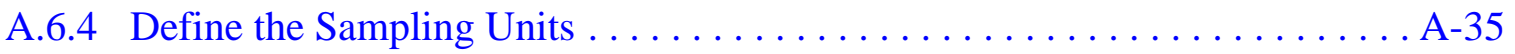

A.7.0 Step 5 - Develop the Analytic Approach ........................ A-36

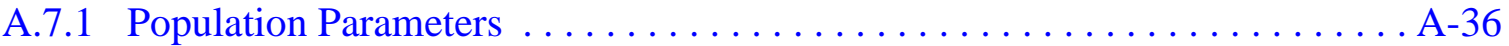

A.7.2 Action Levels ................................ A-36

A.7.2.1 Chemical PALs.......................... A-37

A.7.2.2 Total Petroleum Hydrocarbon PALs . . . . . . . . . . . . . . A-38

A.7.2.3 Radionuclide PALs.......................... A-38

A.7.3 Decision Rules . . . . . . . . . . . . . . . . . . . . . . . . A-38

A.8.0 Step 6 - Specify Performance or Acceptance Criteria . . . . . . . . . . . . . . . A-40

A.8.1 Decision Hypotheses. . . . . . . . . . . . . . . . . . . . . . . . . . A-40

A.8.2 False Negative Decision Error $\ldots \ldots \ldots \ldots \ldots \ldots \ldots \ldots \ldots \ldots \ldots \ldots$ A -40

A.8.3 False Positive Decision Error $\ldots \ldots \ldots \ldots \ldots \ldots \ldots \ldots \ldots \ldots \ldots \ldots \ldots \ldots \ldots \ldots$

A.9.0 Step 7 - Develop the Plan for Obtaining Data $\ldots \ldots \ldots \ldots \ldots \ldots \ldots \ldots$ A-44

A.9.1 Decision I Sampling . . . . . . . . . . . . . . . . . . . . . . . . A4

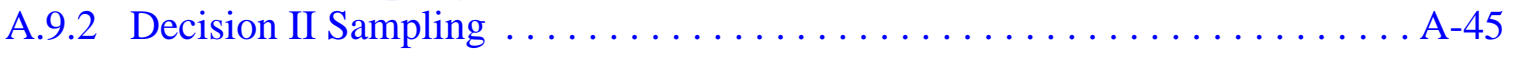




\section{Table of Contents (Continued)}

A.9.3 Corrective Action Site 06-20-04, National Cementers Dry Well . . . . . . . . . A-45

A.9.4 CAS 06-99-09, Birdwell Test Hole . . . . . . . . . . . . . . . . . . A-47

A.9.5 Corrective Action Site 25-60-03, E-MAD Stormwater

Discharge and Piping. ..................... A-49

A.9.6 Corrective Action Site 25-64-01, Vehicle Washdown and Drainage Pit . . . . A-51

A.10.0 References. . . . . . . . . . . . . . . . . . . . . . . . . . . . A-53

Appendix B - Project Organization

B.1.0 Project Organization . . . . . . . . . . . . . . . .

Appendix C - Nevada Division of Environmental Protection Comments 


\section{List of Figures}

Number

Title

Page

1-1 Nevada Test Site Map with CAU 556 CAS Locations . . . . . . . . . . . . 2

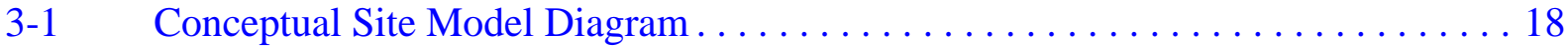

3-2 Conceptual Site Model for CAS 06-20-04 and CAS 06-99-09. . . . . . . . 19

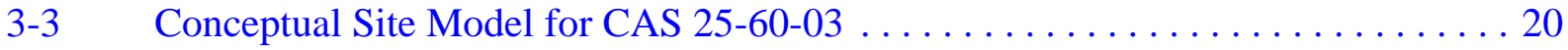

3-4 Conceptual Site Model for CAS $25-64-01 \ldots \ldots \ldots \ldots \ldots \ldots \ldots \ldots \ldots$

3-5 Risk-Based Corrective Action Decision Process $\ldots \ldots \ldots \ldots \ldots \ldots \ldots \ldots$

A.2-1 Corrective Action Unit 556, CAS Location Map . . . . . . . . . . . . . A-4

A.2-2 Site Sketch of CAS 06-20-04, National Cementers Dry Well . . . . . . . . . . A-5

A.2-3 Site Sketch of CAS 06-99-09, Birdwell Test Hole . . . . . . . . . . . . A-7

A.2-4 Site Sketch of CAS 25-60-03, E-MAD Stormwater Discharge and Piping ..... A-9

A.2-5 Site Sketch of CAS 25-64-01, Vehicle Washdown and Drainage Pit. . . . . . . A-12

A.3-1 Conceptual Site Model for CAS 06-20-04 and CAS 06-99-09. . . . . . . . . A-20

A.3-2 Conceptual Site Model for CAS $25-60-03 \ldots \ldots \ldots \ldots \ldots \ldots \ldots \ldots \ldots$ A-21

A.3-3 Conceptual Site Model for CAS 25-64-01 . . . . . . . . . . . . . . . . . A-22

A.9-1 Proposed Sample Locations at CAS $06-20-04 \ldots \ldots \ldots \ldots \ldots \ldots \ldots$. . . . . . . . .

A.9-2 Proposed Sample Locations at CAS $06-99-09 \ldots \ldots \ldots \ldots \ldots \ldots \ldots \ldots$. . . . . . .

A.9-3 Proposed Sample Locations at CAS $25-60-03 \ldots \ldots \ldots \ldots \ldots \ldots \ldots \ldots$. . . . . . . . . .

A.9-4 Proposed Sample Locations at CAS $25-64-01 \ldots \ldots \ldots \ldots \ldots \ldots \ldots \ldots$. . . . . . . . 


\section{List of Tables}

Number

Title

Page

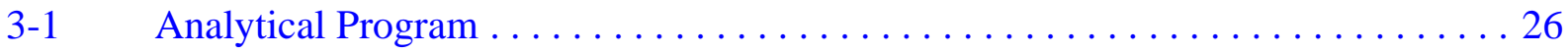

3-2 Constituents Reported by Analytical Methods ...................... 27

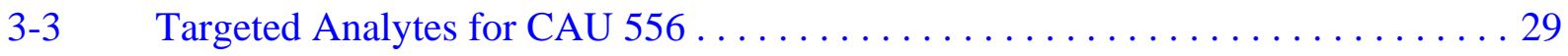

3-4 Analytical Requirements for Radionuclides for CAU $556 \ldots \ldots \ldots \ldots \ldots$

3-5 Analytical Requirements for Chemical COPCs for CAU $556 \ldots \ldots \ldots \ldots \ldots$

5-1 Waste Management Regulations and Requirements ................. 46

6-1 Laboratory and Analytical Performance Criteria for CAU 556

Data Quality Indicators . . . . . . . . . . . . . . . . . . . . . . 55

7-1 Corrective Action Investigation Activity Durations $\ldots \ldots \ldots \ldots \ldots$

A.3-1 DQO Meeting Participants for CAU 556 November 14, $2006 \ldots \ldots \ldots \ldots$. . . . 13

A.3-2 Conceptual Site Model Description of Elements for

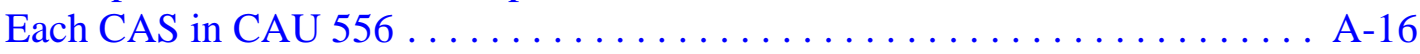

A.3-3 Analytical Program (Includes Waste Characterization Analyses) ........ . A-24

A.3-4 Targeted Contaminants for CAU $556 \ldots \ldots \ldots \ldots \ldots \ldots \ldots \ldots \ldots$ A-25

A.3-5 Land-Use and Exposure Scenarios $\ldots \ldots \ldots \ldots \ldots \ldots \ldots \ldots \ldots \ldots$ A-27

A.6-1 Spatial Boundaries of CAU 556 CASs $\ldots \ldots \ldots \ldots \ldots \ldots \ldots \ldots \ldots$ A-35

A.6-2 Practical Constraints for the CAU 556 Field Investigation............ A-35 


\section{List of Acronyms and Abbreviations}

ASTM American Society for Testing and Materials

bgs Below ground surface

CADD Corrective Action Decision Document

CAI Corrective Action Investigation

CAIP Corrective Action Investigation Plan

CAS Corrective Action Site

CAU Corrective Action Unit

Cd Cadmium

CERCLA Comprehensive Environmental Response, Compensation, and Liability Act

CFR Code of Federal Regulations

COC Contaminant of concern

COPC Contaminant of potential concern

CSM Conceptual site model

DOE U.S. Department of Energy

DOT U.S. Department of Transportation

DQI Data quality indicator

DQO Data quality objective

DRO Diesel-range organics

E-MAD Engine Maintenance, Assembly, and Disassembly

EPA U.S. Environmental Protection Agency

EQL Estimated quantitation limit

FADL $\quad$ Field Activity Daily Log

FAL Final action level

FFACO Federal Facility Agreement and Consent Order 


\section{Acronyms and Abbreviations (Continued)}

\begin{tabular}{|c|c|}
\hline $\mathrm{ft}$ & Foot \\
\hline HWAA & Hazardous waste accumulation area \\
\hline IDW & Investigation-derived waste \\
\hline in. & Inch \\
\hline ISMS & Integrated Safety Management System \\
\hline LCS & Laboratory control sample \\
\hline LCSD & Laboratory control sample duplicate \\
\hline MDC & Minimum detectable concentration \\
\hline $\mathrm{mg} / \mathrm{kg}$ & Milligrams per kilogram \\
\hline $\mathrm{mg} / \mathrm{L}$ & Milligrams per liter \\
\hline $\mathrm{mi}$ & Mile \\
\hline mrem/yr & Millirem per year \\
\hline MS & Matrix spike \\
\hline MSD & Matrix spike duplicate \\
\hline N/A & Not applicable \\
\hline NAC & Nevada Administrative Code \\
\hline NCRP & National Council on Radiation Protection and Measurement \\
\hline ND & Normalized difference \\
\hline NDEP & Nevada Division of Environmental Protection \\
\hline NEPA & National Environmental Policy Act \\
\hline NNSA/NSO & $\begin{array}{l}\text { U.S. Department of Energy, National Nuclear Security Administration } \\
\text { Nevada Site Office }\end{array}$ \\
\hline NRS & Nevada Revised Statutes \\
\hline NSTec & National Security Technologies, LLC \\
\hline
\end{tabular}




\section{Acronyms and Abbreviations (Continued)}

\begin{tabular}{|c|c|}
\hline NTS & Nevada Test Site \\
\hline NTSWAC & Nevada Test Site Waste Acceptance Criteria \\
\hline NV/YMP & Nevada Yucca Mountain Project \\
\hline PAL & Preliminary action level \\
\hline $\mathrm{Pb}$ & Lead \\
\hline PCB & Polychlorinated biphenyl \\
\hline $\mathrm{pCi} / \mathrm{g}$ & Picocuries per gram \\
\hline $\mathrm{pCi} / \mathrm{L}$ & Picocuries per liter \\
\hline POC & Performance Objective for the Certification of Nonradioactive Hazardous Waste \\
\hline PPE & Personal protective equipment \\
\hline ppm & Parts per million \\
\hline PRG & Preliminary remediation goal \\
\hline PVC & Polyvinyl chloride \\
\hline QA & Quality assurance \\
\hline QAPP & Quality Assurance Project Plan \\
\hline QC & Quality control \\
\hline RadCon & Radiological control \\
\hline RBCA & Risk-based corrective action \\
\hline RCA & Radiologically controlled area \\
\hline $\mathrm{RCP}$ & Reactor Control Point \\
\hline RCRA & Resource Conservation and Recovery Act \\
\hline RL & Reporting limit \\
\hline RMA & Radioactive material area \\
\hline RPD & Relative percent difference \\
\hline
\end{tabular}




\section{Acronyms and Abbreviations (Continued)}

$\begin{array}{ll}\text { SDWS } & \text { Safe Drinking Water Standards } \\ \text { SNJV } & \text { Stoller-Navarro Joint Venture } \\ \text { SSTL } & \text { Site-specific target level } \\ \text { SVOC } & \text { Semivolatile organic compound } \\ \text { TCA } & \text { Test Cell A } \\ \text { TCC } & \text { Test Cell C } \\ \text { TPH } & \text { Total petroleum hydrocarbons } \\ \text { TSCA } & \text { Toxic Substance Control Act } \\ \text { UGTA } & \text { Underground Test Area } \\ \text { VOC } & \text { Volatile organic compound } \\ \text { \%R } & \text { Percent recovery }\end{array}$




\section{Executive Summary}

Corrective Action Unit (CAU) 556, Dry Wells and Surface Release Points, is located in Areas 6 and 25 of the Nevada Test Site, 65 miles northwest of Las Vegas, Nevada. Corrective Action Unit 556 is comprised of four corrective action sites (CASs) listed below:

- 06-20-04, National Cementers Dry Well

- 06-99-09, Birdwell Test Hole

- 25-60-03, E-MAD Stormwater Discharge and Piping

- 25-64-01, Vehicle Washdown and Drainage Pit

These sites are being investigated because existing information on the nature and extent of potential contamination is insufficient to evaluate and recommend corrective action alternatives. Additional information will be obtained by conducting a corrective action investigation before evaluating corrective action alternatives and selecting the appropriate corrective action for each CAS. The results of the field investigation will support a defensible evaluation of viable corrective action alternatives that will be presented in the Corrective Action Decision Document.

The sites will be investigated based on the data quality objectives (DQOs) developed on November 14, 2006, by representatives of the Nevada Division of Environmental Protection; U.S. Department of Energy, National Nuclear Security Administration Nevada Site Office; Stoller-Navarro Joint Venture; and National Security Technologies, LLC. The DQO process was used to identify and define the type, amount, and quality of data needed to develop and evaluate appropriate corrective actions for CAU 556.

Appendix A provides a detailed discussion of the DQO methodology and the DQOs specific to each CAS.

The scope of the corrective action investigation for CAU 556 includes the following activities:

- Conduct radiological surveys.

- $\quad$ Perform field screening.

- Collect and submit environmental samples for laboratory analysis to determine nature and extent of any contaminants from each CAS. 
- Collect samples of source material to determine the potential for a release.

- Collect samples of potential remediation wastes.

This Corrective Action Investigative Plan has been developed in accordance with the Federal Facility Agreement and Consent Order that was agreed to by the State of Nevada, the U.S. Department of Energy, and the U.S. Department of Defense. Under the Federal Facility Agreement and Consent Order, this Corrective Action Investigative Plan will be submitted to the Nevada Division of Environmental Protection and field work will be conducted following approval. 


\subsection{Introduction}

This Corrective Action Investigation Plan (CAIP) contains project-specific information including facility descriptions, environmental sample collection objectives, and criteria for conducting site investigation activities at Corrective Action Unit (CAU) 556, Dry Wells and Surface Release Points, Nevada Test Site (NTS), Nevada.

This CAIP has been developed in accordance with the Federal Facility Agreement and Consent Order (FFACO) (1996); agreed to by the State of Nevada, the U.S. Department of Energy (DOE) and the U.S. Department of Defense.

Corrective Action Unit 556 is located in Areas 6 and 25 of the NTS, approximately 65 miles (mi) northwest of Las Vegas, Nevada (Figure 1-1). Corrective Action Unit 556 is comprised of four corrective action sites (CASs) shown on Figure 1-1 and listed below:

- 06-20-04, National Cementers Dry Well

- 06-99-09, Birdwell Test Hole

- 25-60-03, E-MAD Stormwater Discharge and Piping

- 25-64-01, Vehicle Washdown and Drainage Pit

The Corrective Action Investigation (CAI) will include field inspections, radiological surveys, geophysical surveys, sampling of environmental media, analysis of samples, and assessment of investigation results, where appropriate. Data will be obtained to support corrective action alternative evaluations and waste management decisions.

\subsection{Purpose}

The CASs in CAU 556 are being investigated because hazardous and/or radioactive constituents may be present in concentrations that could potentially pose a threat to human health and the environment. Existing information on the nature and extent of potential contamination is insufficient to evaluate and recommend corrective action alternatives for the CASs. Additional information will be generated by conducting a CAI before evaluating and selecting corrective action alternatives. 


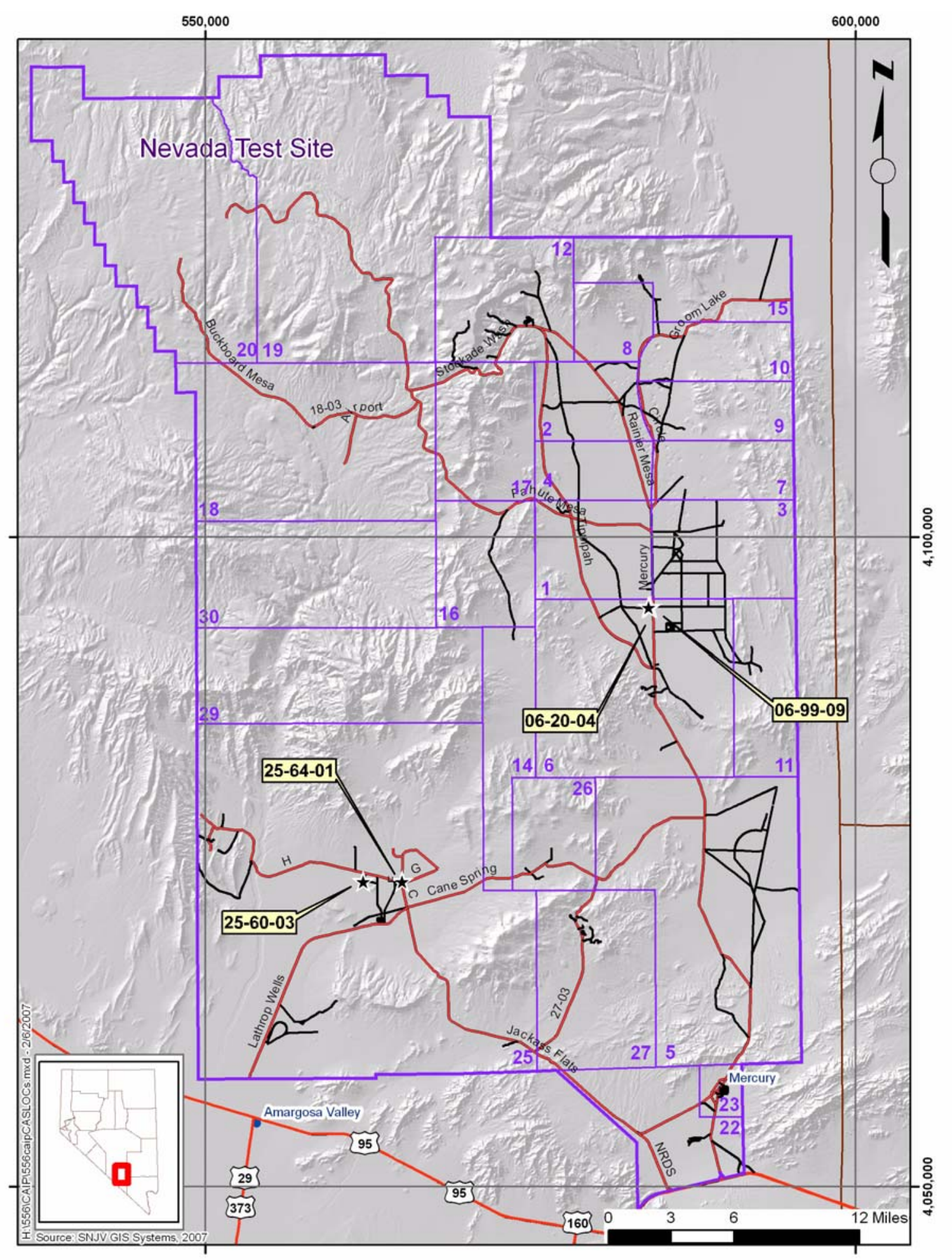

Figure 1-1

Nevada Test Site Map with CAU 556 CAS Locations 


\subsubsection{Corrective Action Unit 556 History and Description}

Corrective Action Unit 556, Dry Wells and Surface Release Points; consists of three inactive sites, and one passively active site, and is located in the northern portion of Area 6 and the central portion of Area 25. The four CAU 556 sites consist of a dry well and associated piping, tool and instrument testing holes, stormwater catch basins and discharge piping including an outfall, a vehicle washdown area, and adjacent drainage pit. The CAU 556 CASs were used to support activities at the Area 6 Well 3 Yard and Area 25 Engine Maintenance, Assembly, and Disassembly (E-MAD) Complex. Operational histories for each CAU 556 CAS are detailed in Section 2.2.

\subsubsection{Data Quality Objective Summary}

The sites will be investigated based on data quality objectives (DQOs) developed by representatives of the Nevada Division of Environmental Protection (NDEP); DOE, National Nuclear Security Administration Nevada Site Office (NNSA/NSO); Stoller-Navarro Joint Venture (SNJV); and National Security Technologies, LLC (NSTec). The DQOs are used to identify and define the data type, amount, and quality needed to develop and evaluate appropriate corrective actions for CAU 556. This CAIP describes the investigative approach developed to collect the data needs identified in the DQO process. While a detailed discussion of the DQO methodology and the DQOs specific to each CAS are presented in Appendix A, a summary of the DQO process is discussed below.

The DQO problem statement for CAU 556 is: "Existing information on the nature and extent of potential contamination is insufficient to evaluate and recommend corrective action alternatives for the CASs in CAU 556.” To address this, the resolution of two decisions statements is required:

- Decision I: "Is any contaminant of potential concern (COPC) present in environmental media within the CAS at a concentration exceeding its corresponding final action level (FAL)?" For judgmental sampling, any contaminant associated with a CAS activity that is present at concentrations exceeding its corresponding FAL will be defined as a contaminant of concern (COC). A COC may also be defined as a contaminant that, in combination with other similar contaminants, is determined to jointly pose an unacceptable risk based on a multiple constituent analysis (NNSA/NSO, 2006). If a COC is detected, then Decision II must be resolved. If a COC is not detected, the investigation for that CAS is complete. 
- Decision II: "If a COC is present, is sufficient information available to evaluate potential corrective action alternatives? Sufficient information is defined to include:

- Identifying the lateral and vertical extent of COC contamination in media.

- The information needed to determine potential remediation waste types.

- The information needed to evaluate the feasibility of remediation alternatives.

The informational inputs and data needs to resolve the problem statement and the decision statements were generated as part of the DQO process for this CAU and are documented in Appendix A. The information necessary to resolve the DQO decisions will be generated for each CAU 556 CAS by collecting and analyzing samples generated during a field investigation. The presence of contamination at each CAS will be determined by collecting and analyzing samples using the following criterion:

- $\quad$ Samples must be collected in areas most likely to contain a COC.

\subsection{Scope}

To generate information needed to resolve the decision statements identified in the DQO processes, the scope of the CAI for CAU 556 includes the following activities:

- Move surface debris and/or materials to facilitate sampling, as needed.

- Conduct radiological surveys.

- $\quad$ Perform field screening.

- Collect and submit environmental samples for laboratory analysis to determine the nature and extent of any contamination.

- Determine extent of the contamination released by each CAS.

- Collect samples of source material to determine the potential for a release.

- Collect samples of potential remediation wastes.

- $\quad$ Collect quality control (QC) samples.

Contamination of environmental media originating from activities not identified in the conceptual site model (CSM) of any CAS will not be considered as part of this CAU unless the CSM and the DQOs 
are modified to include the release. As such, contamination originating from these sources will not be considered for sample location selection and/or will not be considered COCs for Decision II. If such contamination is present, the contamination will be identified as part of another CAS (new or existing).

\subsection{Corrective Action Investigation Plan Contents}

Section 1.0 presents the purpose and scope of this CAIP, while Section 2.0 provides background information about CAU 556. Objectives of the investigation, including CSMs, are presented in Section 3.0. Field investigation and sampling activities are discussed in Section 4.0, and waste management issues for this project are discussed in Section 5.0. General field and laboratory quality assurance (QA) (including collection of QA samples) are presented in Section 6.0 and in the Industrial Sites Quality Assurance Project Plan (QAPP) (NNSA/NV, 2002a). The project schedule and records availability are discussed in Section 7.0 and Section 8.0 provides a list of references.

Appendix A is a detailed discussion of the DQO methodology and the DQOs specific to each CAS, while Appendix B provides information on the project organization. 


\subsection{Facility Description}

Corrective Action Unit 556 is comprised of four CASs that were grouped together based on the geographical location of the sites (a dry well and test holes in Area 6 and drainage systems in Area 25), technical similarities, and the agency responsible for closure. Corrective Action Sites 06-20-04 and 06-99-09 are located at the Well 3 Yard within Area 6. The drainage systems are in Area 25 and include CASs 25-60-03, near the Reactor Control Point (RCP), and 25-64-01, located at the E-MAD Facility.

\subsection{Physical Setting}

The following sections describe the general physical settings of Areas 6 and 25 of the NTS. General background information pertaining to topography, geology, hydrogeology, and climatology are provided for these specific areas of the NTS region in the Geologic Map of the Nevada Test Site, Southern Nevada (USGS, 1990); CERCLA Preliminary Assessment for DOE's Nevada Operations Office Nuclear Weapons Testing Areas (DRI, 1988); Final Environmental Impact Statement, Nevada Test Site, Nye County, Nevada (ERDA, 1977); and the Final Environmental Impact Statement for the Nevada Test Site and Off-Site Locations in the State of Nevada (DOE/NV, 1996).

\subsubsection{Yucca Flat}

Corrective Action Sites 06-20-04 and 06-99-09 are located within the Yucca Flat Hydrographic Area of the NTS. Yucca Flat is a closed basin, which is slowly filling with alluvial deposits eroding from the surrounding mountains (USGS, 1996). Carbonate rocks primarily underlie the alluvium in parts of Yucca Flat and form much of the surrounding mountains in this area (DOE/NV, 1996).

The direction of groundwater flow in Yucca Flat generally is from the northeast to southwest. Within the overlying alluvial and volcanic aquifers, lateral groundwater flow occurs from the margins to the center of the basin and downward into the carbonate aquifer (USGS, 1996). The average annual precipitation at Station UCC on the Yucca Flat dry lake is 6.62 inches (in.) (ARL/SORD, 2006). The annual recharge rate to the Yucca Flat area is relatively low (1.76 millimeters), and the thickness of the unsaturated zone extends to more than 600 feet (ft) below ground surface (bgs) (USGS, 1996). 
The nearest groundwater well to CAS 06-20-04 and CAS 06-99-09 is Groundwater Characterization Well ER-6-1, located in the far northeast corner of Area 6. Pumping tests conducted in August 1992 by Desert Research Institute indicated a static water level of approximately 1,546 ft bgs (DRI, 1993). Water Well 3, a water supply well drilled in 1951, is located approximately $900 \mathrm{ft}$ west of CAS 06-20-04. In March 1993, a static water level at Water Well 3 was measured at 1,533 ft bgs (DOE/NV, 1996).

\subsubsection{Jackass Flats}

Corrective Action Sites 25-60-03 and 25-64-01 lie within Jackass Flats basin in Area 25 of the NTS. The basin is surrounded on the southwest by a low-lying drainage divide, and on the northwest by the southeastern slopes of Lookout Peak; on the north and northeast by small, rugged hills, and on the south by the northern slopes of Skull Mountain (DRI, 1988). The erosion of the surrounding Tertiary and Paleozoic uplands has filled the basin and created a layer of alluvium and colluvium to a depth of up to 1,205 ft (DOE, 1988; USGS and AEC, 1964).

The closest well to the site is the J-11 Water Well, drilled in 1957 and located approximately $1.7 \mathrm{mi}$ southwest of CAS 25-60-03. The depth to groundwater at this well ranges from 1,039 to 1,042 ft bgs (USGS and DOE, 2005). The J-13 Water Well is located in Area 25 approximately 7.0 mi west of CAS 25-60-03 and was drilled in 1963 to a depth of 3,498 ft. The depth of groundwater at this well ranges from 925 to $932 \mathrm{ft}$ bgs.

Mean annual precipitation in Area 25 has been reported to be 5.67 in. (ARL/SORD, 2006).

\subsection{Operational History}

The subsequent sections provide a description of the use and history of each CAS in CAU 556 that may have resulted in potential releases to the environment. The CAS-specific summaries are designed to describe the current definition of each CAS and illustrate all significant activities.

\subsubsection{Corrective Action Site 06-20-04, National Cementers Dry Well}

This CAS is the potential release of wastes to the dry well, associated piping, and surrounding soils. The dry well contains a horizontally-oriented perforated polyvinyl chloride (PVC) pipe that is 
approximately 2 to $3 \mathrm{ft}$ bgs. The effluent from the metals shop enters the perforated PVC pipe where it seeps into a bed of washed aggregate that extends to the bottom of the unlined well. The engineering drawing indicates that the well is approximately $4 \mathrm{ft}$ in diameter and contains approximately $1.5 \mathrm{ft}$ of untreated building paper between the PVC pipe and the native material on the surface.

Although there is uncertainty as to the specific period of operations of the National Cementers Facility, it is believed that it operated from 1963 to approximately 1992. The dry well became active when the Facility opened in 1963.

Figure A.2-2 shows the locations of the dry well, the cast iron line running from the concrete pad of the former National Cementers Facility, and surrounding structures.

\subsubsection{Corrective Action Site 06-99-09, Birdwell Test Hole}

This CAS is the potential release of wastes to the wells, the soils surrounding the Birdwell Test Hole, and two adjacent instrument holes. The Birdwell Test Hole was drilled in 1976, is $6 \mathrm{ft}$ in diameter, approximately $47 \mathrm{ft}$ deep, and is believed to be sealed at the bottom. Casing within the well was used to provide a watertight environment when testing was performed and is still in place. The Birdwell Test Hole is located south of the Tool Storage Bighole Building at the Birdwell Complex in the Area 6 Well 3 Yard, and was used for the waterproof testing of tools that required the casing in the hole to be filled with water. A 6-ft diameter metal plate covers the Birdwell Test Hole. The center of the metal plate is cut out and is covered by a wooden plank. Use of the Birdwell Test Hole ended in 1992.

Two smaller diameter boreholes are located on the east and west sides of the Birdwell Test Hole and were used for testing instrument downhole signals. These boreholes were cased and filled with water during testing. Occasionally, a small amount of liquid dishwashing soap was added to the water to enhance signal transmission. The eastern hole is covered by a rock, and the western hole is not covered. 
The area surrounding the site has been graded over, and the area around the test holes is covered with gravel and some vegetation. There is no debris present at this CAS. Figure A.2-3 shows the Birdwell Test Hole and surrounding features.

\subsubsection{Corrective Action Site 25-60-03, E-MAD Stormwater Discharge and Piping}

This CAS is the potential release of wastes to the surrounding soils from a stormwater discharge system containing three concrete catch basins, a manhole, and a discharge pipe at an outfall located southwest of the E-MAD Building in Area 25 of the NTS. All three catch basins are dry, extend approximately $10 \mathrm{ft}$ bgs, and have a layer of soil at the bottom. There is approximately $100 \mathrm{ft}$ between each catch basin. The catch basins are connected by an 18-in. diameter corrugated metal pipe that ends at an outfall southwest of the catch basins; a distance of approximately $750 \mathrm{ft}$ from the easternmost catch basin where the system begins. The piping is visible at the outfall located in the desert outside the southwest section of the E-MAD Facility. The manhole with a metal cover, which is just outside the southwest section of the fenced E-MAD Facility and in the middle of a dirt access road, is between the last catch basin and the outfall. Approximately $315 \mathrm{ft}$ of the corrugated piping lies between the manhole and the outfall.

The western edge of the concrete driveway to the former Flammable Materials Storage Building is adjacent to the first (easternmost) catch basin. Fluids from the Flammable Materials Storage Building were occasionally poured onto the soil around the catch basin and sometimes into the catch basin itself, according to interviewees. Corrective Action Site 25-25-04 (CAU 398) involved the removal of soil from in front of the easternmost catch basin that was contaminated with total petroleum hydrocarbons (TPH), polychlorinated biphenyls (PCBs), and Resource Conservation and Recovery Act (RCRA) metals (cadmium [Cd] and lead [Pb]). The CAS was clean closed after verification samples were collected and determined to be free of contaminants from the excavation created by removal of contaminated material. The excavation was brought to grade with clean fill material. It is believed that some of the contaminated soils may have entered the easternmost catch basin and the storm drain discharge system from runoff during storms with sufficient flow volume to wash soils into the system. There is also the potential that the sources of COCs identified in the CAS 25-25-04 investigation may have been poured directly into the catch basin. 
The stormwater system is active and channels water away from the E-MAD Facility. The fenced area of the E-MAD facility sees occasional use, so it is not considered abandoned or inactive, and any activities may, but are not expected to, impact investigative activities involving the stormwater discharge system. Figure A.2-4 shows the stormwater drainage system and surrounding features.

\subsubsection{Corrective Action Site 25-64-01,Vehicle Washdown and Drainage Pit}

This CAS is the potential release of wastes from the vehicle washdown pad, drainage pit, and soils beneath these features to the surrounding soils. The washdown area and drainage pit are located near the RCP at the northeast corner of the intersection of F and G Roads in Area 25 of the NTS. The environmental concern is believed to be TPH contamination of the soil. The washdown pad was used to clean vehicles exiting the RCP Facility that indicated the presence of radionuclide contamination. Washdown was accomplished using a garden hose, blotter cloths, wire brushes, and possibly detergents and Freon-10 (i.e., carbon tetrachloride). The vehicle washdown area consists of a flat area covered with cobble-sized fill and is approximately 100 by $40 \mathrm{ft}$ in area. The drainage pit resembles a borrow pit and measures approximately 300 by 70 by $7 \mathrm{ft}$ deep. Access to the pit is from the south side. A drainage channel runs from the vehicle washdown area to the drainage pit. A 2-in. diameter pipe with an elbow is visible at the southern end of the cobble-covered area of the vehicle washdown area. A geophysical survey indicates that the pipe in the vehicle washdown area is the same pipe that protrudes into the drainage pit and was presumably in place to drain the washdown area before overflow. The drainage pit also contains various debris, including downed barbed-wire fencing, an illegible yellow metal sign, a dismantled electrical box system, black cables, yellow rope, and miscellaneous metal and wood debris. The drainage pit is located on the eastern side of the vehicle washdown area.

Interviewees indicate that there is both TPH contamination and elevated radionuclide readings in the area beneath the overflow drainage pipe in the drainage pit. Interviewees also indicated the possibility that Freon-10 was used in the decontamination process. Detergent phosphates are also likely to be present from the washdown activities. On September 21, 2006, a radiological survey was conducted and indicated no radiological readings within the washdown pad or drainage pit that were above 1.4 times the background. The higher readings were associated with the vehicle washdown pad and the area within the drainage pit near the outfall from the washdown pad. 
This CAS is adjacent to CAS 25-07-07, Vehicle Washdown (CAU 165), where vehicles with detected radiation were also decontaminated on a washdown pad. The only COC identified at CAS 25-07-07 was TPH. The soil impacted by TPH was removed, verification samples were collected, and the site was backfilled with clean material and brought to grade in 2005. Corrective Action Site 25-07-02, Vehicle Washdown Area (CAU 240), located at the intersection of F and J Roads in Area 25, was a similar vehicle washdown station in operation between 1958 and 1973. Analytical results for CAS 25-07-02 indicated TPH and radionuclide contamination above their respective PALs. A similar time interval of operation is expected for the CAS 25-64-01, Vehicle Washdown and Drainage Pit. Figure A.2-5 shows the vehicle washdown pad, drainage pit, and surrounding features.

\subsection{Waste Inventory}

Available documentation, interviews with former site employees, process knowledge, and general historical NTS practices were used to identify wastes that may be present. Historical information and site visits indicate that the sites contain wastes such as construction materials, electrical debris, weathered broken glass, and other miscellaneous debris.

\subsubsection{Corrective Action Site 06-20-04, National Cementers Dry Well}

Potential waste types include hydrocarbon waste, RCRA hazardous waste, and volatile organic waste.

\subsubsection{Corrective Action Site 06-99-09, Birdwell Test Hole}

Potential waste types include sanitary industrial wastes.

\subsubsection{Corrective Action Site 25-60-03, E-MAD Stormwater Discharge and Piping}

Potential waste types include hydrocarbons, RCRA metals (Cd and Pb), and PCBs.

\subsubsection{Corrective Action Site 25-64-01, Vehicle Washdown and Drainage Pit Potential waste types include hydrocarbons.}




\subsection{Release Information}

Potentially affected media for all CASs include surface and shallow subsurface soil. The following subsections contain CAS-specific descriptions of known or potential releases associated with CAU 556.

\subsubsection{Corrective Action Site 06-20-04, National Cementers Dry Well}

There is a potential for release of contaminants from the shallow (approximately $5 \mathrm{ft}$ deep) National Cementers Dry Well, leaks from the associated piping system that leads from the former metals shop to the dry well (a distance of approximately $10 \mathrm{ft}$ ), and the surrounding soils in contact with the unlined well.

Volatile organic compounds (VOCs) and RCRA metals may have been released from the piping and the dry well, if these liquids were disposed of from within the metals shop. The metals shop used VOCs and other solvents for metals degreasing operations. If a release occurred, contaminants are expected to be located in the soil within close proximity to the dry well and the associated piping. However, there is no process knowledge indicating that any of these solvents were placed within the metals shop drain. The dry well is believed to be grouted to ground level so that the potential for additional input to the dry well does not exist. There is also a concrete slab near where the dry well is expected to be, but it is not believed to cover the grouted dry well. If the dry well is grouted and the drain grate on the metals shop concrete pad is still open, rainwater may reside within the cast iron pipe. The CAS (other than the former metals shop concrete pad) has been covered with gravel and graded, and the dry well is believed to be beneath the gravel.

\subsubsection{Corrective Action Site 06-99-09, Birdwell Test Hole}

There is no expectation of release of contaminants from the 47-ft deep Birdwell Test Hole or the two associated instrument test holes because the design of the holes was to provide a watertight environment to test instrumentation for downhole use. The Birdwell Test Hole still contains water, so the potential for liquid release is negligible. The instrument holes are also cased and were filled with water when in use. The water in the holes was occasionally pumped out, reducing the amount of time that liquids resided within the casing of the holes. There is no record, process knowledge, or interviewee recollection that the watertightness of any of the holes was compromised, resulting in 
potential leakage to the surrounding soils. All interviewees indicated that only water was placed in the well for the waterproof testing. Occasionally, detergent in the form of dishwashing liquid was added to the water for the tests. There is no record or process knowledge of any placement of potential contaminants into any of the instrument holes or the Birdwell Test Hole. Even if the liquid within the Birdwell Test Hole included wastes, there is no expectation that the surrounding soils were affected due to the design of the wells and the fact that liquid still exists within the holes.

\subsubsection{Corrective Action Site 25-60-03, E-MAD Stormwater Discharge and Piping}

There is a potential for the release of contaminants from the piping connecting the catch basins and manhole and from the effluent of the water discharged into the desert southwest of the facility during storm events. The release of contamination is somewhat limited to the current contents of the catch basins and associated piping, as a significant source of contamination that is believed to have entered this system has been addressed. Corrective Action Site 25-25-04, Oil Spills (CAU 398) contained soils contaminated with TPH, PCBs, and RCRA metals (Cd and Pb) that may have entered the CAS before they were removed in 2002. Following the collection of clean verification samples, the excavation was backfilled with clean fill material. These contaminated soils were immediately adjacent to the entry to the easternmost catch basin. Furthermore, interviewees indicated that not only were liquids discarded onto the soils near the catch basin, some liquids were likely poured directly into the catch basin as well. As a catchment system, the migration of contaminated soils near the easternmost catch basin through the stormwater drainage system during storm events is likely. Stained soils are visible within the easternmost catch basin, and staining is visible within the end of the discharge piping. Staining of the soil is also visible at the outfall of the piping that runs the length of the system.

\subsubsection{Corrective Action Site 25-64-01, Vehicle Washdown and Drainage Pit}

There is a potential for a release of contaminants from the vehicle washdown pad and the drainage pit connected to the vehicle washdown pad, as well as the soils beneath each of these features. The potential contaminant at this CAS is TPH, because the pad was used to wash down tires and undersides of vehicles that had detectable levels of radiation on them. The radiation detected was usually associated with the vehicles tires, but in the process, the wheel wells and portions of the undercarriage of the vehicles were also washed. A radiation survey of the washdown pad and the 
drainage pit conducted in September 2006 indicated radiation at levels no higher than 1.4 times background. A pipe connects the vehicle washdown pad to the drainage pit in what appears to be an overfill channel to route excess water from the pad to the drainage pit. A drainage channel also runs from the washdown pad to the drainage pit. Additional contamination may arise from the use of Freon-10, sometimes used for vehicle decontamination.

\section{$2.5 \quad$ Investigative Background}

The subsequent sections summarize the investigations conducted at the CAU 556 sites. More detailed discussions of these investigations are in Appendix A.

\subsubsection{Corrective Action Site 06-20-04, National Cementers Dry Well}

No analytical or radiological data have been collected from this CAS. On October 19, 2005, a geophysical survey was conducted that encompassed approximately 3,700 square feet at CAS 06-20-04. The concrete area where the dry well was thought to exist did not show any anomalous readings consistent with the well being a dry earth well with no casing. Additionally, the survey did not identify the 3-in. cast iron drain line that runs from the former metal shop to the dry well as in the engineering drawings. No further information is available for this CAS.

\subsubsection{Corrective Action Site 06-99-09, Birdwell Test Hole}

No analytical, geophysical, or radiological results are identified for this CAS.

\subsubsection{Corrective Action Site 25-60-03, E-MAD Stormwater Discharge and Piping}

No samples have been collected from the soils within any of the catch basins or the piping connecting them and leading to the outfall in the desert. Contamination of sediments and soils associated with CAS 25-60-03 are likely those associated with CAS 25-25-04 (CAU 398), as the contamination was identified in the soils immediately adjacent to the easternmost catch basin of the system and there is the possibility that similar contaminants were placed directly into the catch basin. Soil samples collected immediately adjacent to the easternmost catch basin for CAS 25-25-04, Oil Spills (CAU 398), contained TPH-diesel-range organics (DRO) in the range of 510 to 3,600 milligrams per kilogram (mg/kg), TPH-oil-range organics in the range of 2,000 to 18,000 mg/kg, PCBs in the range 
of 77 to $920 \mathrm{mg} / \mathrm{kg}$, and RCRA metals ( $\mathrm{Pb}$ and Cd) above respective preliminary remediation goals (PRGs) and/or RCRA action levels. Staining of approximately $1 \mathrm{ft}$ in depth (estimated) is visible at the outfall of the piping that connects the three catch basins. No samples have been collected at or near the outfall.

A geophysical survey was conducted in November 2005 at CAS 25-60-03 and found the pipe visible at the outfall in the desert off the southwest section of the E-MAD Complex is connected without interruption to the manhole that is located between the westernmost catch basin and the outfall. The distance from the end of the pipe at the outfall to the manhole is approximately $312 \mathrm{ft}$ (Fahringer, 2005) and is entirely outside the fenced E-MAD Facility.

\subsubsection{Corrective Action Site 25-64-01, Vehicle Washdown and Drainage Pit}

No samples have been collected from this CAS. The adjacent CAU 165 CAS (25-07-07, Vehicle Washdown) identified levels of TPH that were above the action level of $100 \mathrm{mg} / \mathrm{kg}$ in the area around the vehicle washdown pad. The use of CAS 25-64-01 was identical to that of CAS 25-07-07, resulting in the potential for TPH contamination similar to that found at CAS 25-64-01. Interviewees indicate that CAS 25-64-01 was used in a manner similar to CAS 25-07-07.

A geophysical survey conducted on October 19, 2005, identified that the pipe seen on both the vehicle washdown side and the drainage pit side of an intervening berm is the same pipe. A natural channel also connects the vehicle washdown pad to the drainage pit some $10 \mathrm{ft}$ north of the pipe that connects the two. No underground piping that connected the CAS 25-64-01 drainage pit to a sump located near the southern end of the drainage pit in CAS 25-07-07 was identified (Fahringer, 2005).

On September 19, 2006, a radiological survey was conducted of the vehicle washdown pad, the drainage pad, and the area surrounding the CAS footprint. No radiological contamination was identified greater than 1.4 times background, with the higher levels located in the vehicle washdown pad and the area around the outfall of the pipe connecting the pad to the drainage pit. 


\subsubsection{National Environmental Policy Act}

The Final Environmental Impact Statement for the Nevada Test Site and Off-Site Locations in the State of Nevada (DOE/NV, 1996) includes site investigation activities such as those proposed for CAU 556.

In accordance with the NNSA/NSO National Environmental Policy Act (NEPA) Compliance Program, a NEPA checklist will be completed before beginning site investigation activities at CAU 556. This checklist requires NNSA/NSO project personnel to evaluate proposed project activities against a list of potential impacts that include, but are not limited to: air quality, chemical use, waste generation, noise level, and land use. Completion of the checklist results in a determination of the appropriate level of NEPA documentation by the NNSA/NSO NEPA Compliance Officer. This will be accomplished before mobilization for the field investigation. 


\subsection{Objectives}

This section presents an overview of the DQOs for CAU 556 and formulation of the CSM. Also presented is a summary listing of the contaminants reasonably suspected to be present at each CAS, the COPCs (i.e., target contaminants), preliminary action levels (PALs) for the investigation, and the process used to establish FALs. Additional details and figures depicting the CSM are in Appendix A.

\subsection{Conceptual Site Model}

The CSM describes the most probable scenario for current conditions at each site and defines the assumptions that are the basis for identifying the future land use, contaminant sources, release mechanisms, migration pathways, exposure points, and exposure routes. The CSM is also used to support appropriate sampling strategies and data collection methods. The CSM has been developed for CAU 556 using information from the physical setting, potential contaminant sources, release information, historical background information, knowledge from similar sites, and physical and chemical properties of the potentially affected media and COPCs. Figure 3-1 depicts a tabular representation of the conceptual pathways to receptors from CAU 556 sources. Figure 3-2, Figure 3-3, and Figure 3-4 depict graphical representation of the CSM for CASs 06-20-04 and 06-99-09, 25-60-03, and 25-64-01, respectively. If evidence of contamination that is not consistent with the presented CSM is identified during investigation activities, the situation will be reviewed, CSM revised, DQOs re-assessed, and a recommendation made as to how best to proceed. In such cases, decision-makers (Section A.3.1) will be notified and offered the opportunity to comment on and/or concur with the recommendation.

The subsequent sections discuss future land use and the identification of exposure pathways (i.e., combination of source, release, migration, exposure point, and receptor exposure route) for the CAU. 


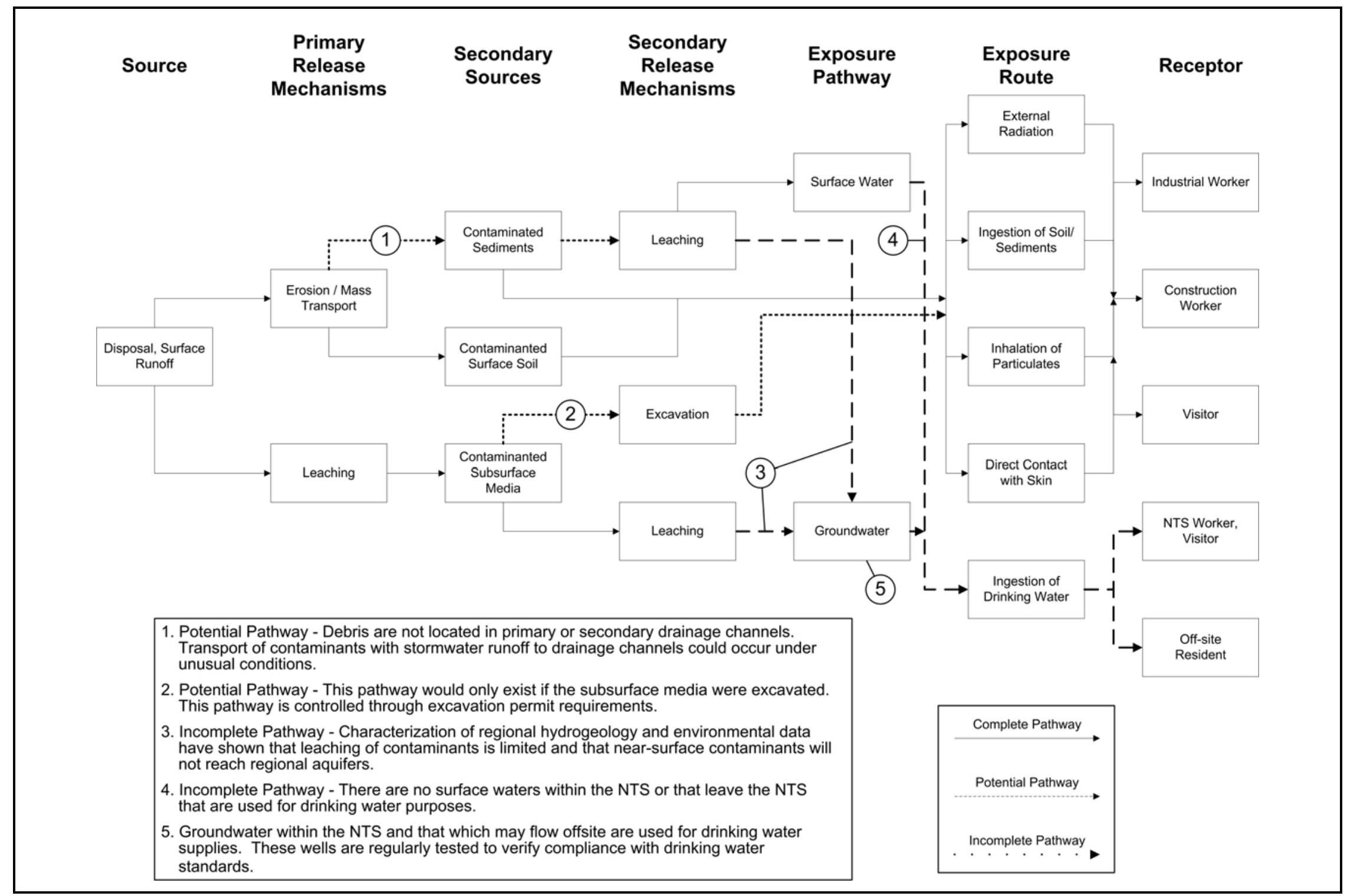

Figure 3-1

Conceptual Site Model Diagram 


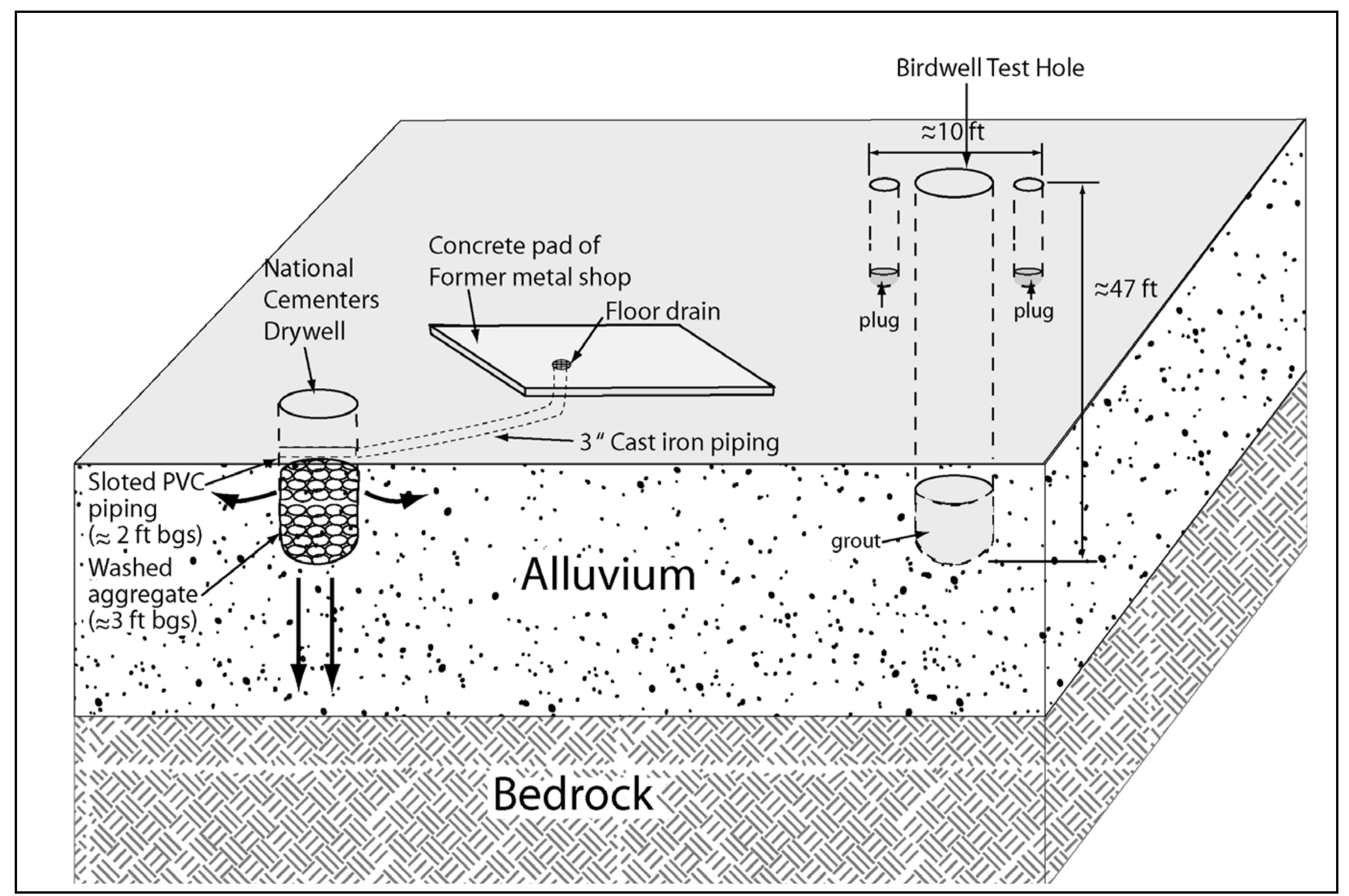

Figure 3-2

Conceptual Site Model for CAS 06-20-04 and CAS 06-99-09 


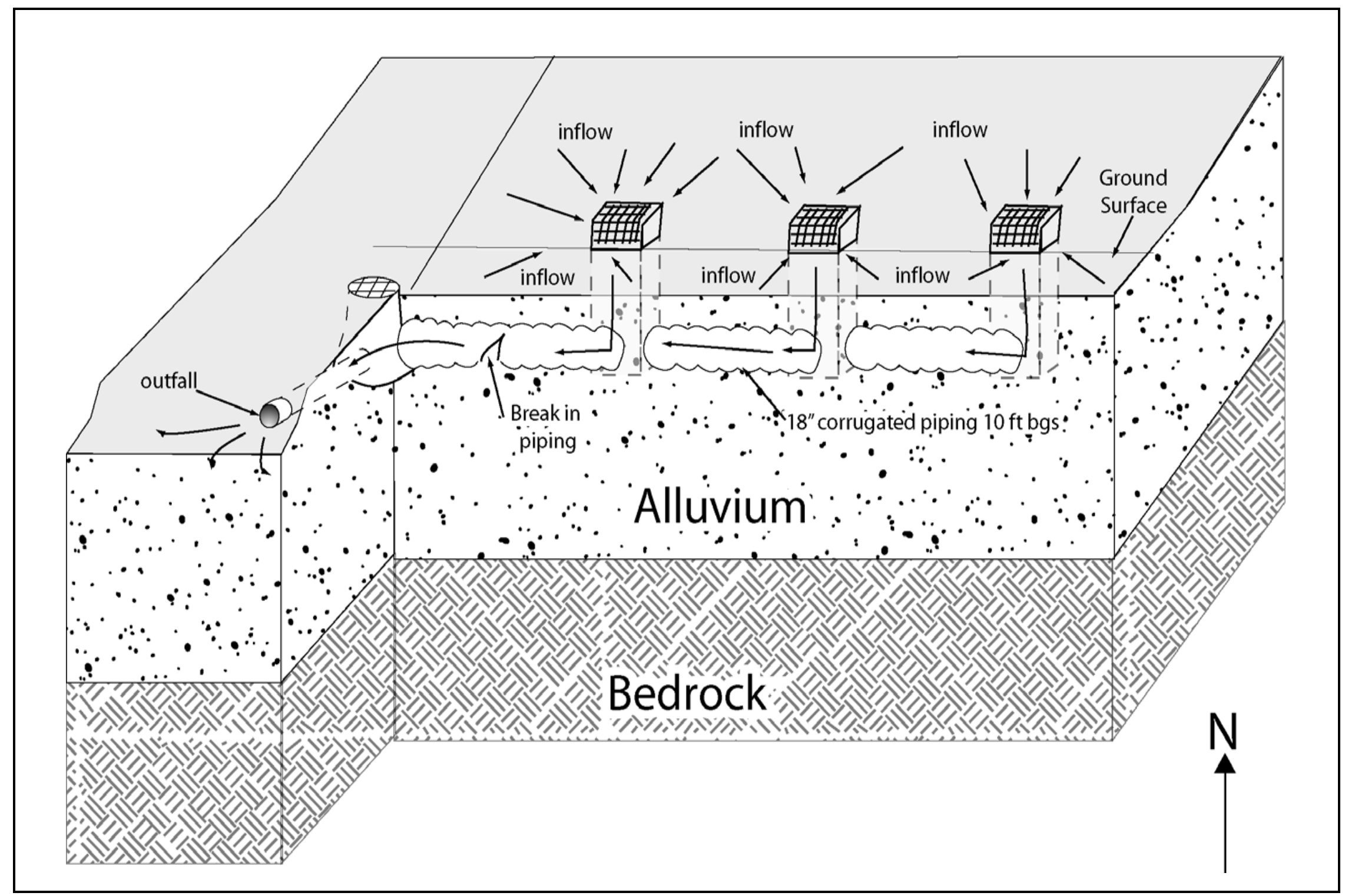

Figure 3-3

Conceptual Site Model for CAS 25-60-03 


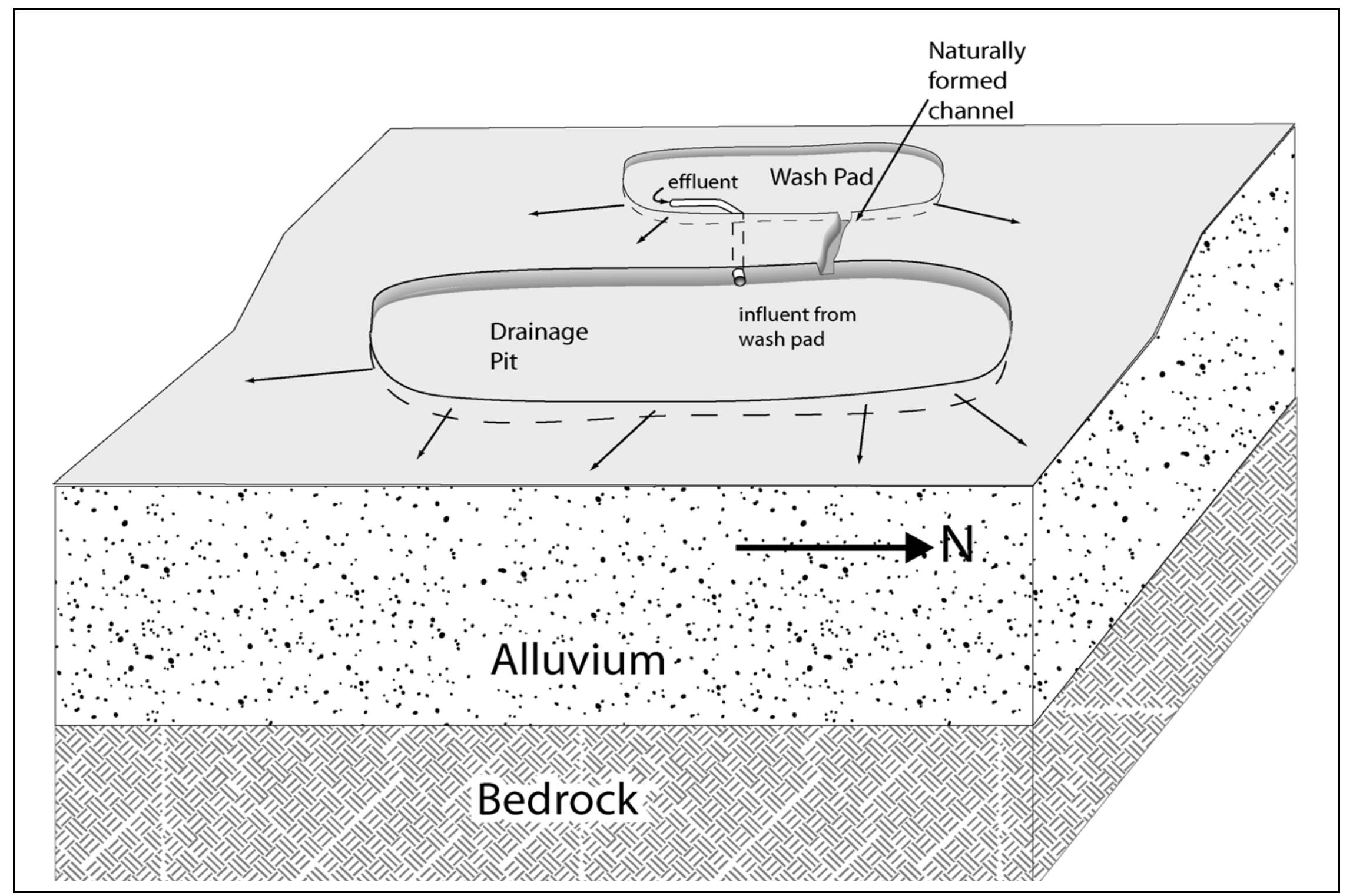

Figure 3-4

Conceptual Site Model for CAS 25-64-01 


\subsubsection{Land Use and Exposure Scenarios}

Corrective Action Sites 06-20-04 and 06-99-09 are located in the land-use zone described as the "Nuclear Test Zone.” This area is reserved for dynamic experiments, hydrodynamic tests, and underground nuclear weapons and weapons effects tests. This zone includes compatible defense and non-defense research, development, and testing activities (DOE/NV, 1998).

Corrective Action Sites 25-60-03 and 25-64-01 are located in the land-use zone described as the "Research, Test, and Experiment Zone.” This area is designated for small-scale research and development projects and demonstrations, pilot projects, outdoor tests, and experiments for the development, quality assurance, or reliability of material and equipment under controlled conditions. This zone includes compatible defense and non-defense research, development and testing projects and activities (DOE/NV, 1998).

All land-use zones where the CAU 556 CASs are located dictate future land use, and restrict current and future land use to nonresidential (i.e., industrial) activities.

The occasional land-use exposure scenario was established for all CAU 556 CASs based on current and projected future land uses.

- Occasional Use Area. This exposure scenario assumes occasional work activities at a site. This scenario addresses exposure to industrial workers who are not assigned to the area as a regular work site but may occasionally use the site. A site worker under this scenario is assumed to be on the site for an equivalent of 80 hours (or 10 days) per year, for 5 years.

\subsubsection{Contaminant Sources}

The primary contaminant sources for CAU 556 are potential chemical releases from surface disposals and leaks and from infiltrations from underground structures (e.g., disposal wells).

\subsubsection{Release Mechanisms}

Contaminants may have been released into soils through infiltration or precipitation run-off. 


\subsubsection{Migration Pathways}

Subsurface migration pathways at the CASs are expected to be predominantly vertical, although spills or leaks at the ground surface may also have limited lateral migration before infiltration. The depth of infiltration (shape of the subsurface contaminant plume) will be dependent upon the type, volume, and duration of the discharge; as well as the presence of relatively impermeable layers that could modify vertical or horizontal transport pathways, both on the ground surface (e.g., concrete) and in the subsurface (e.g., caliche layers).

Subsurface migration pathways for CAS 06-20-04 include vertical movement from the bottom of the dry well, as well as minor lateral movement through the soils along the wall of the dry well.

Surface migration pathways for CAS 25-64-01 include lateral movement along the vehicle washdown pad and through the drainage pit. Subsurface migration includes vertical movement through the soils beneath the washdown pad and the drainage pit.

Subsurface migration through the stormwater discharge system of CAS 25-60-03, coupled with surface migration at the discharge outfall, is a migration pathway for contaminants. Stormwater flow events provide an intermittent mechanism for both vertical and horizontal transport of contaminants. Contaminated sediments entrained by these stormwater events would be carried by the streamflow to locations where the flowing water loses energy and the sediments drop out. These locations are readily identifiable as sedimentation areas. Flow from the outfall is generally southwest, following the natural sloping of Jackass Flats, and the direction in which the outfall is oriented. The watershed for the drainage system is a potential source for the addition of contaminants to the drainage system during subsequent storms.

Surface migration pathways at the CASs are expected to be minor as all the CASs have shallow surface slopes and the potential release sites are not located in or near natural drainages. However, concentrated stormwater runoff may have caused a more widespread distribution of contaminants at the mouth of the drainage system outfall at CAS 25-60-03 because of recurring surges of effluent from the drainage system during intense storms.

Migration is influenced by physical and chemical characteristics of the contaminants and media. Contaminant characteristics include, but are not limited to: solubility, density, and adsorption 
potential. Media characteristics include permeability, porosity, water saturation, sorting, chemical composition, and organic content. In general, contaminants with low solubility, high affinity for media, and high density can be expected to be found relatively close to release points. Contaminants with high solubility, low affinity for media, and low density can be expected to be found further from release points. In addition, contaminants with a high affinity for media may be transported to more remote locations within the stormwater drainage system owing to the transport of contaminationcarrying media fines during storms with high-volume flows. These factors affect the migration pathways and potential exposure points for the contaminants in the various media under consideration.

Infiltration and percolation of precipitation serves as a driving force for downward migration of contaminants. However, due to high potential for evapotranspiration (annual potential evapotranspiration at the Area 3 Radiological Waste Management Site has been estimated at 62.6 in. [Shott et al., 1997] and limited precipitation for this region approximately 6 in. annually [Winograd and Thordarson, 1975]), percolation of infiltrated precipitation at the NTS does not provide a significant mechanism for vertical migration of contaminants to groundwater (DOE/NV, 1992).

\subsubsection{Exposure Points}

Exposure points for both CSMs are expected to be areas of surface contamination where visitors and site workers will come in contact with soil surface. Subsurface exposure points may also exist if construction workers come in contact with contaminated media during excavation activities.

\subsubsection{Exposure Routes}

Exposure routes to site workers include ingestion, inhalation, and/or dermal contact (absorption) from disturbance of contaminated soils and/or systems (e.g., stormwater catch basins and associated piping). Site workers may also be exposed to radiation by performing activities in proximity to radiologically contaminated materials.

\subsubsection{Additional Information}

Information concerning topography, geology, climatic conditions, hydrogeology, floodplains, and infrastructure at the CAU 556 CASs are in Section 2.1, as they pertain to the investigation. This 
information has been addressed in the CSM and will be considered during the evaluation of corrective action alternatives, as applicable. Climatic and site conditions (e.g., surface and subsurface soil descriptions), as well as specific structure descriptions, will be recorded during the CAI. Areas of erosion and deposition within the outfall surface flow will be qualitatively evaluated by a hydrologist to provide any additional information on potential offsite migration of contamination.

\subsection{Contaminants of Potential Concern}

The COPCs for CAU 556 are defined as the list of constituents represented by the analytical methods identified in Table 3-1 for Decision I environmental samples taken at each CAS. The constituents reported for each analytical method are listed in Table 3-2.

The list of COPCs is intended to encompass all of the contaminants that could potentially be present at each CAS. These COPCs were identified during the planning process through the review of site history, process knowledge, employee interviews, past investigation efforts (where available), and inferred activities associated with the CASs. Contaminants detected at other similar or other NTS sites were also included in the COPC list to reduce the uncertainty about potential contamination at the CASs, because complete information regarding activities performed at the CAU 556 sites is not available.

During the review of site history documentation, process knowledge information, personal interviews, past investigation efforts (where available), and inferred activities associated with the CASs, some of the COPCs were identified as targeted contaminants at specific CASs. Targeted contaminants are those COPCs for which evidence in the available site and process information suggests that they may be reasonably suspected to be present at a given CAS. The targeted contaminants are required to meet a more stringent completeness criteria than other COPCs thus providing greater protection against decision error (Sections A.1.0 through A.7.0). Targeted contaminants for each CAU 556 CAS are identified in Table 3-3. 
Table 3-1

Analytical Programa

\begin{tabular}{|c|c|c|c|c|}
\hline Analyses & $\begin{array}{c}\text { CAS } \\
06-20-04\end{array}$ & $\begin{array}{c}\text { CAS } \\
06-99-09\end{array}$ & $\begin{array}{c}\text { CAS } \\
25-60-03\end{array}$ & $\begin{array}{c}\text { CAS } \\
25-64-01\end{array}$ \\
\hline \multicolumn{5}{|c|}{ Organic Contaminants of Potential Concern (COPCs) } \\
\hline Total Petroleum Hydrocarbons-Diesel-Range Organics & $\mathrm{X}$ & $\mathrm{X}$ & $\mathrm{X}$ & $\mathrm{X}$ \\
\hline Total Petroleum Hydrocarbons-Gasoline-Range Organics & $\mathrm{X}$ & $\mathrm{X}$ & $\mathrm{X}$ & $\mathrm{X}$ \\
\hline Polychlorinated Biphenyls & $\mathrm{X}$ & & $\mathrm{X}$ & $\mathrm{X}$ \\
\hline Semivolatile Organic Compounds & $\mathrm{X}$ & $\mathrm{X}$ & $\mathrm{X}$ & $\mathrm{X}$ \\
\hline Volatile Organic Compounds & $\mathrm{X}$ & $\mathrm{X}$ & $\mathrm{X}$ & $\mathrm{X}$ \\
\hline \multicolumn{5}{|c|}{ Inorganic COPCs } \\
\hline Resource Conservation and Recovery Act Metals & $\mathrm{X}$ & $\mathrm{X}$ & $\mathrm{X}$ & $\mathrm{X}$ \\
\hline Beryllium & $\mathrm{X}$ & $x$ & $x$ & $x$ \\
\hline \multicolumn{5}{|c|}{ Radionuclide COPCs } \\
\hline Gamma Spectroscopy $^{b}$ & $\mathrm{X}$ & $\mathrm{X}$ & $\mathrm{X}$ & $\mathrm{X}$ \\
\hline Isotopic Radionuclides & $x$ & $x$ & $x$ & $\mathrm{X}$ \\
\hline
\end{tabular}

$X=$ Required analytical method

${ }^{a}$ The COPCs are the constituents reported from the analytical methods listed.

${ }^{\mathrm{b}}$ Results of gamma analysis will be used to determine whether further radioanalytical analysis is warranted. 
Table 3-2

Constituents Reported by Analytical Methods

(Page 1 of 2)

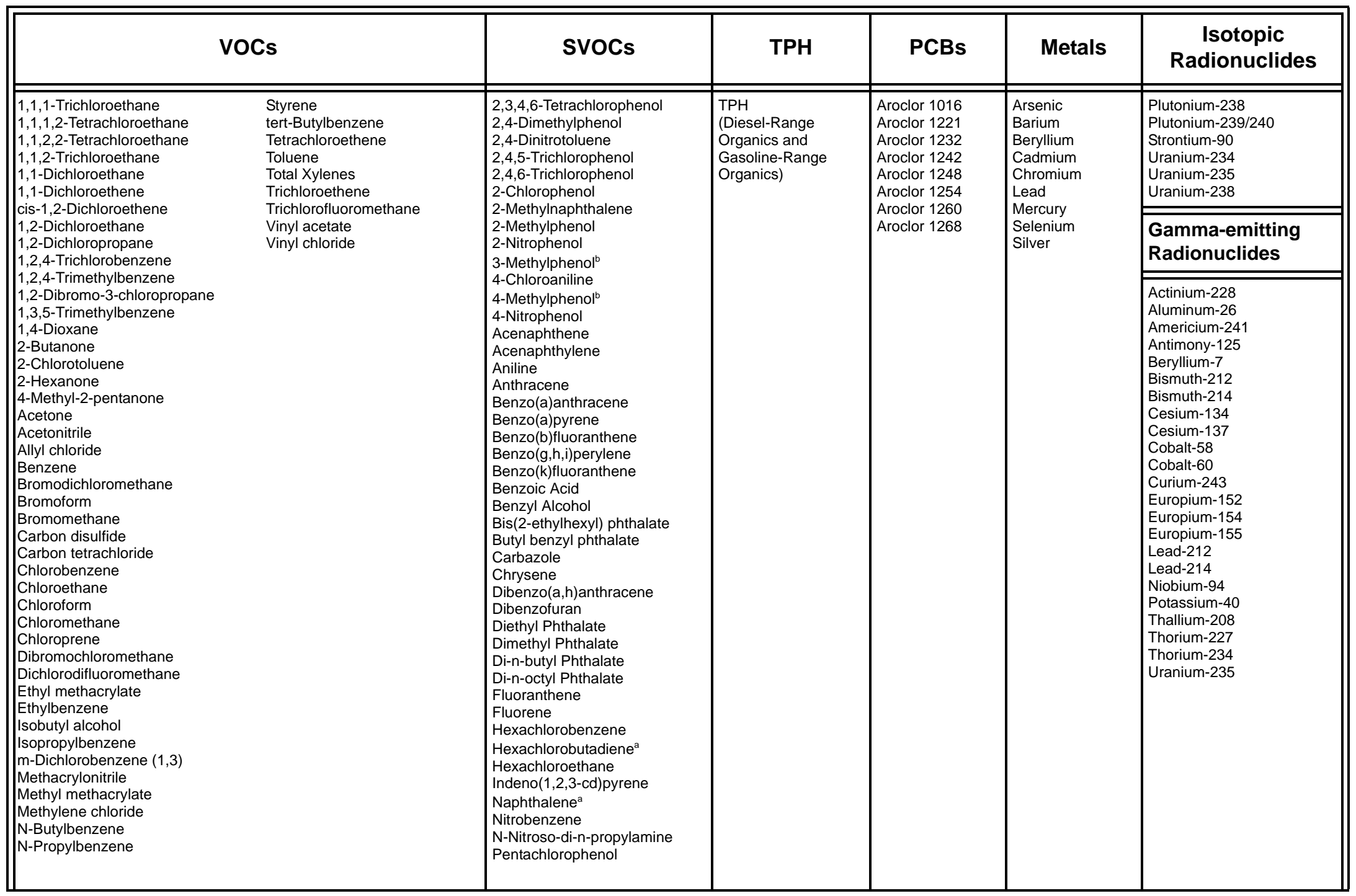


Table 3-2

Constituents Reported by Analytical Methods

(Page 2 of 2)

\begin{tabular}{|l|l|l|l|l|}
\hline \multicolumn{1}{|c|}{ VOCs } & \multicolumn{1}{|c|}{ SvOCs } & TPH & PCBs & \multicolumn{1}{c|}{$\begin{array}{c}\text { Isotopic } \\
\text { Radionuclides }\end{array}$} \\
\hline \hline $\begin{array}{l}\text { o-Dichlorobenzene (1,2) } \\
\text { p-Dichlorobenzene (1,4) } \\
\text { p-isopropyltoluene } \\
\text { sec-Butylbenzene }\end{array}$ & $\begin{array}{l}\text { Phenanthrene } \\
\text { Phenol } \\
\text { Pyrene } \\
\text { Pyridine }\end{array}$ & & \\
\hline
\end{tabular}

aMay be reported with VOCs

$\mathrm{PCB}=$ Polychlorinated biphenyl

bMay be reported as 3,4-methylpenol

SVOC = Semivolatile organic compound

$\mathrm{TPH}=$ Total petroleum hydrocarbons

VOC $=$ Volatile organic compound 
Table 3-3

Targeted Analytes for CAU 556

\begin{tabular}{|c|c|}
\hline $\begin{array}{c}\text { Corrective Action } \\
\text { Site }\end{array}$ & Targeted Analyte(s) \\
\hline \hline $06-20-04$ & TPH-DRO, VOCs \\
\hline $25-60-03$ & TPH-DRO, RCRA Metals, PCBs \\
\hline $25-64-01$ & TPH-DRO, carbon tetrachloride \\
\hline
\end{tabular}

$\mathrm{DRO}=$ Diesel-range organics

$\mathrm{PCB}=$ Polychlorinated biphenyl

RCRA = Resource Conservation and Recovery Act

$\mathrm{TPH}=$ Total petroleum hydrocarbons

VOC $=$ Volatile organic compound

\subsection{Preliminary Action Levels}

The PALs presented in this section are to be used for site screening purposes. They are not necessarily intended to be used as cleanup action levels or FALs. However, they are useful in screening out contaminants that are not present in sufficient concentrations to warrant further evaluation, therefore, streamlining the consideration of remedial alternatives. The risk-based corrective action (RBCA) process used to establish FALs is described in the Industrial Sites Project Establishment of Final Action Levels (NNSA/NSO, 2006). This process conforms with Nevada Administrative Code (NAC) Section 445A.227, which lists the requirements for sites with soil contamination (NAC, 2006b). For the evaluation of corrective actions, NAC Section 445A.22705 (NAC, 2006c) requires the use of ASTM Method E 1739-95 (ASTM, 1995) to "conduct an evaluation of the site, based on the risk it poses to public health and the environment, to determine the necessary remediation standards (i.e., FALs) or to establish that corrective action is not necessary.”

This RBCA process, summarized in Figure 3-5, defines three tiers (or levels) of evaluation involving increasingly sophisticated analyses:

- Tier 1 - Sample results from source areas (highest concentrations) are compared to action levels based on generic (non-site-specific) conditions (i.e., the PALs established in the CAIP). The FALs may then be established as the Tier 1 action levels or the FALs may be calculated using a Tier 2 evaluation.

- Tier 2 - Conducted by calculating Tier 2 site-specific target levels (SSTLs) using site-specific information as inputs to the same or similar methodology used to calculate Tier 1 action levels. The Tier 2 SSTLs are then compared to individual sample results from reasonable 


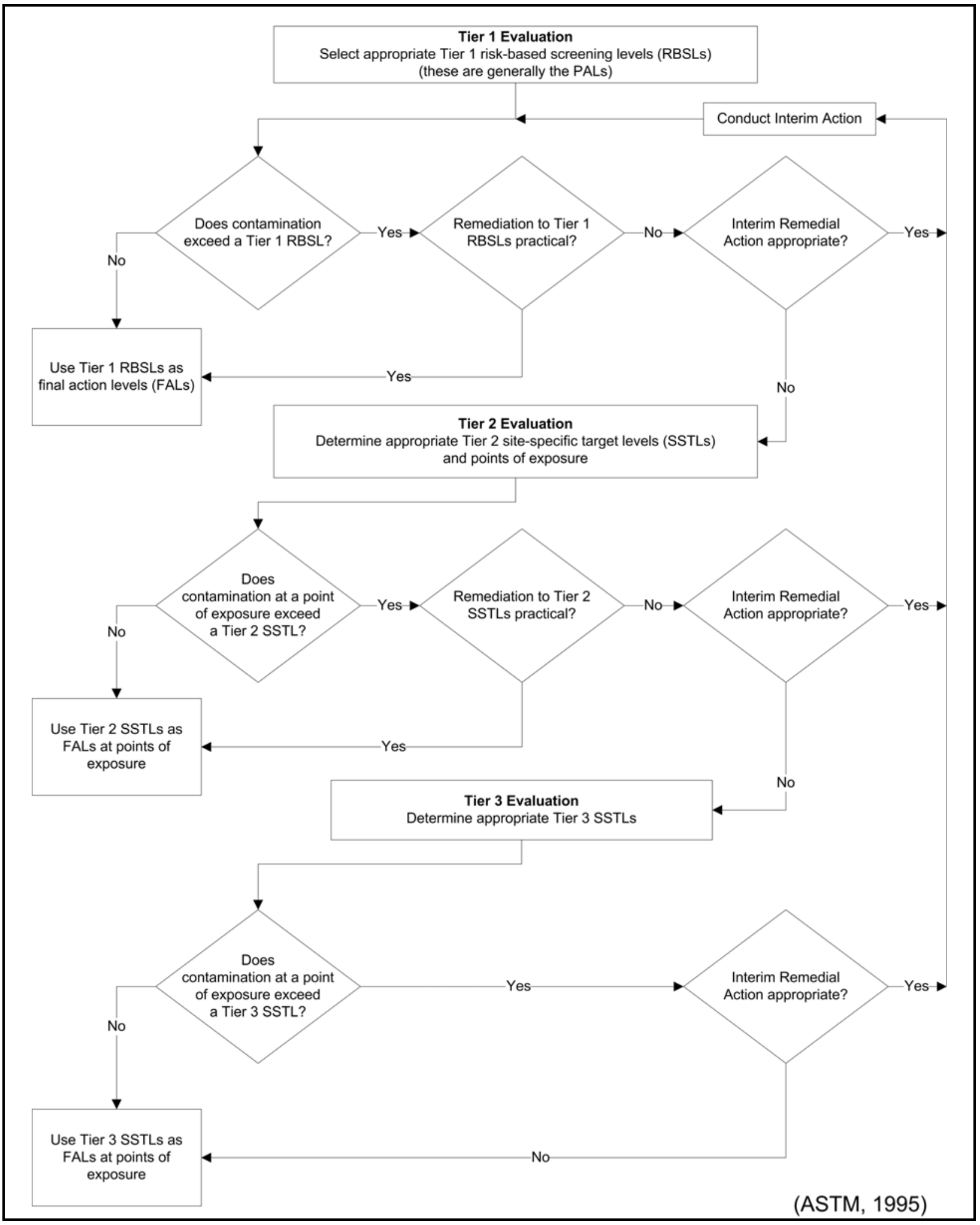

Figure 3-5

Risk-Based Corrective Action Decision Process 
points of exposure (as opposed to the source areas as is done in Tier 1) on a point-by-pointbasis. Total TPH concentrations will not be used for risk-based decisions under Tier 2 or Tier 3. Rather, the individual chemicals of concern will be compared to the SSTLs.

- Tier 3 - Conducted by calculating Tier 3 SSTLs on the basis of more sophisticated risk analyses using methodologies described in Method E 1739-95 that consider site-, pathway-, and receptor-specific parameters.

This process includes a provision for conducting an interim remedial action if necessary and appropriate. The decision to conduct an interim action may be made at any time during the investigation and at any level (tier) of analysis. Decision-makers concurrence is listed in Section A.3.1 and will be obtained before any interim action is implemented. Evaluation of DQO decisions will be based on conditions at the site following completion of any interim actions. Any interim actions conducted will be in the investigation report.

The FALs (along with the basis for their selection) will be proposed in the investigation report where they will be compared to laboratory results in the evaluation of potential corrective actions.

\subsubsection{Chemical PALs}

Except as noted herein, the chemical PALs are defined as the U.S. Environmental Protection Agency (EPA) Region 9 Risk-Based Preliminary Remediation Goals (PRGs) for contaminant constituents in industrial soils (EPA, 2004). Background concentrations for RCRA metals will be used instead of PRGs when natural background concentrations exceed the PRG, as is often the case with arsenic on the NTS. Background is considered the mean plus two standard deviations of the mean for sediment samples collected by the Nevada Bureau of Mines and Geology throughout the Nevada Test and Training Range (formerly the Nellis Air Force Range) (NBMG, 1998; Moore, 1999). For detected chemical COPCs without established PRGs, the protocol used by the EPA Region 9 in establishing PRGs (or similar) will be used to establish PALs. If used, this process will be documented in the investigation report.

\subsubsection{Total Petroleum Hydrocarbon PALs}

The PAL for TPH is 100 parts per million (ppm) as listed in NAC 445A.2272 (NAC, 2006d). 


\subsubsection{Radionuclide PALs}

The PALs for radiological contaminants (other than tritium) are based on the National Council on Radiation Protection and Measurement (NCRP) Report No. 129 recommended screening limits for construction, commercial, industrial land-use scenarios (NCRP, 1999) using a 25 millirem per year (mrem/yr) dose constraint (Murphy, 2004) and the generic guidelines for residual concentration of radionuclides in DOE Order 5400.5 (DOE, 1993). These PALs are based on the construction, commercial, and industrial land-use scenario provided in the guidance and are appropriate for the NTS based on future land use scenarios as presented in Section 3.1.1.

The PAL for tritium is based on the Underground Test Area (UGTA) Project limit of 400,000 picocuries per liter (pCi/L) for discharge of water containing tritium (NNSA/NV, 2002b). The activity of tritium in the soil moisture of soil samples will be reported in units of $\mathrm{pCi} / \mathrm{L}$ for comparison to this PAL.

Solid media such as concrete and/or structures may pose a potential radiological exposure risk to site workers if contaminated. The radiological PAL for solid media will be defined as the unrestricted-release criteria defined in the NV/YMP Radiological Control (RadCon) Manual (NNSA/NSO, 2004).

\subsection{Data Quality Objective Process Discussion}

This section contains a summary of the DQO process that is presented in Appendix A. The DQO process is a strategic planning approach based on the scientific method that is designed to ensure that the data collected will provide sufficient and reliable information to identify, evaluate, and technically defend the recommendation of viable corrective actions (e.g., no further action, clean closure, or closure in place).

The DQO strategy for CAU 556 was developed at the November 14, 2006, DQO meeting. The DQOs were developed to identify data needs, clearly define the intended use of the environmental data, and to design a data collection program that satisfies these purposes. During the DQO discussions for this CAU, the informational inputs or data needs to resolve problem statements and decision statements were documented. 
The problem statement for CAU 556 is: "Existing information on the nature and extent of potential contamination is insufficient to evaluate and recommend corrective action alternatives for the CASs in CAU 556." To address this question, the resolution of two decisions statements is required:

- Decision I: "Is any COC present in environmental media within the CAS?" If a COC is detected, then Decision II must be resolved. Otherwise, the investigation for that CAS is complete.

- Decision II: "If a COC is present, is sufficient information available to evaluate potential corrective action alternatives?” Sufficient information is defined to include:

- Identifying the volume of media containing any COC bounded by analytical sample results in lateral and vertical directions.

- Information needed to characterize investigation derived waste (IDW) for disposal.

- Information needed to determine potential remediation waste types.

- Information needed to evaluate the feasibility of remediation alternatives.

The presence of a COC would require a corrective action. A corrective action may also be necessary if there is a potential for wastes that are present at a site to impose COCs into site environmental media if the wastes were to be released. To evaluate the potential for the stormwater drainage system contents to result in the introduction of a COC to the surrounding environmental media, the following conservative assumptions were made that:

- The system would direct stormwater away from the E-MAD Complex and the contents would be released to the surrounding media at the system outfall.

- The resulting concentration of contaminants at the system outfall would at some time be equal to or greater than the concentration of contaminants in the stormwater drainage system.

- Any soil/sediment contaminant in the stormwater drainage system exceeding the RCRA toxicity characteristic concentration can result in COC introduction into the surrounding media at the system outfall.

- Contaminants located within the drainage system watershed can be washed into the drainage system during storm events and become part of the release mechanism for this CAS, as defined above. 
Sludge containing a contaminant exceeding an equivalent FAL concentration would be considered to be potential source material and would require a corrective action. Structures containing liquids with contaminant concentrations exceeding an equivalent toxicity characteristic action level would be considered to be potential source material and would require a corrective action.

Decision I samples will be submitted to analytical laboratories for the analyses listed in Table 3-1. Decision II samples will be submitted for the analysis of all unbounded COCs. In addition, samples will be submitted for analyses as needed to support waste management or health and safety decisions.

The data quality indicators (DQIs) of precision, accuracy, representativeness, completeness, comparability, and sensitivity needed to satisfy DQO requirements are discussed in Section 6.2. Laboratory data will be assessed in the investigation report to confirm or refute the CSM and determine whether the DQO data needs were met.

To satisfy the DQI of sensitivity (Section 6.2.8), the analytical methods must be sufficient to detect contamination that is present in the samples at concentrations less than or equal to the corresponding FALs. Analytical methods and target analyte minimum detectable concentrations (MDCs) for each CAU 556 COPC are provided in Tables 3-4 and 3-5. The MDC is the lowest concentration of a chemical or radionuclide parameter that can be detected in a sample within an acceptable level of error. Due to changes in analytical methodology and changes in analytical laboratory contracts, information in Tables 3-4 and 3-5 that varies from corresponding information in the QAPP will supersede the QAPP (NNSA/NV, 2002a). 
Table 3-4

\section{Analytical Requirements for Radionuclides for CAU 556}

(Page 1 of 2)

\begin{tabular}{|c|c|c|c|c|c|c|}
\hline $\begin{array}{c}\text { Parameterl } \\
\text { Analyte }\end{array}$ & Matrix & $\begin{array}{c}\text { Analytical } \\
\text { Method }\end{array}$ & $\begin{array}{c}\text { Minimum } \\
\text { Detectable } \\
\text { Concentration } \\
{\text { (MDC })^{\mathrm{a}}}^{\text {M }}\end{array}$ & PAL $^{b, c}$ & $\begin{array}{l}\text { Laboratory } \\
\text { Precision } \\
\text { (RPD) }\end{array}$ & $\begin{array}{c}\text { Percent } \\
\text { Recovery } \\
\text { (\%R) }\end{array}$ \\
\hline \multicolumn{7}{|c|}{ Gamma Spectroscopy } \\
\hline Americium-241 & Soil & HASL-300 & $2.0 \mathrm{pCi} / \mathrm{g}^{\mathrm{e}}$ & $12.7 \mathrm{pCi} / \mathrm{g}$ & \multirow{3}{*}{$\begin{array}{c}\text { Relative Percent } \\
\text { Difference (RPD) } \\
35 \% \\
\text { Normalized } \\
\text { Difference } \\
-2<N D<2^{f}\end{array}$} & \multirow{3}{*}{$\begin{array}{c}\text { Laboratory } \\
\text { Control Sample } \\
\text { Recovery } \\
80-120^{9} \text { Percent } \\
\text { Recovery }(\% R)\end{array}$} \\
\hline Cesium-137 & Soil & HASL-300 & $0.5 \mathrm{pCi} / \mathrm{g}^{\mathrm{e}}$ & $12.2 \mathrm{pCi} / \mathrm{g}$ & & \\
\hline Cobalt-60 & Soil & HASL-300 ${ }^{d}$ & $0.5 \mathrm{pCi} / \mathrm{g}^{\mathrm{e}}$ & $2.68 \mathrm{pCi} / \mathrm{g}$ & & \\
\hline \multicolumn{7}{|c|}{ Other Radionuclides } \\
\hline Tritium & Soil & Lab specific & $400 \mathrm{pCi} / \mathrm{L}^{\mathrm{h}}$ & $\begin{array}{c}4.0 \mathrm{E}+05 \\
\mathrm{pCi} / \mathrm{L}^{\mathrm{h}}\end{array}$ & \multirow{7}{*}{$\begin{array}{c}\text { Relative Percent } \\
\text { Difference (RPD) } \\
35 \%\end{array}$} & \multirow{7}{*}{$\begin{array}{c}\text { Laboratory } \\
\text { Control Sample } \\
\text { Recovery } \\
80-120^{9} \text { Percen } \\
\text { Recovery (\%R) } \\
\\
\text { Chemical Yield } \\
30-105^{\mathrm{j}} \% \mathrm{R} \\
\text { (not applicable } \\
\text { for tritium) }\end{array}$} \\
\hline Plutonium-238 & Soil & $\begin{array}{c}\text { ASTM } \\
\text { C } 1001-02^{i}\end{array}$ & $0.05 \mathrm{pCi} / \mathrm{g}$ & $13.0 \mathrm{pCi} / \mathrm{g}$ & & \\
\hline Plutonium-239/240 & Soil & $\begin{array}{c}\text { ASTM } \\
\text { C } 1001-02^{i}\end{array}$ & $0.05 \mathrm{pCi} / \mathrm{g}$ & $12.7 \mathrm{pCi} / \mathrm{g}$ & & \\
\hline Strontium-90 & Soil & HASL $300^{d}$ & $0.5 \mathrm{pCi} / \mathrm{g}$ & $838 \mathrm{pCi} / \mathrm{g}$ & & \\
\hline Uranium-234 & Soil & $\begin{array}{c}\text { ASTM } \\
\text { C } 1000-00^{k}\end{array}$ & $0.05 \mathrm{pCi} / \mathrm{g}$ & $143 \mathrm{pCi} / \mathrm{g}$ & & \\
\hline Uranium-235 & Soil & $\begin{array}{c}\text { ASTM } \\
\text { C } 1000-00^{k}\end{array}$ & $0.05 \mathrm{pCi} / \mathrm{g}$ & $17.6 \mathrm{pCi} / \mathrm{g}$ & & \\
\hline Uranium-238 & Soil & $\begin{array}{c}\text { ASTM } \\
\text { c } 1000-00^{k}\end{array}$ & $0.05 \mathrm{pCi} / \mathrm{g}$ & $105 \mathrm{pCi} / \mathrm{g}$ & & \\
\hline
\end{tabular}

${ }^{\mathrm{a}}$ The MDC is the lowest concentration of a radionuclide, if present in a sample, that can be detected with a 95 percent confidence level.

${ }^{\mathrm{b}}$ The PALs for soil are based on the National Council for Radiation Protection and Measurement (NCRP) Report No. 129 Recommended Screening Limits for Contaminated Surface Soil and Review of Factors Relevant to Site-Specific Studies (NCRP, 1999) scaled to $25 \mathrm{mrem} / \mathrm{yr}$ dose and the guidelines for residual concentration of radionuclides in DOE Order 5400.5 (DOE, 1993).

${ }^{C}$ PALs for liquids will be developed as needed.

${ }^{\mathrm{d}}$ The Procedures Manual of the Environmental Measurements Laboratory, HASL-300 (DOE, 1997).

${ }^{\mathrm{e}}$ MDCs vary depending on the presence of other gamma-emitting radionuclides in the sample and are relative to the MDC for Cesium-137.

${ }^{f} \mathrm{ND}$ is not RPD, it is another measure of precision used to evaluate duplicate analyses. The ND is calculated as the difference between two results divided by the square root of the sum of the squares of total propagated uncertainties (Paar and Porterfield, 1997).

${ }^{9}$ Contract Laboratory Program Statement of Work for Inorganic Analysis (EPA, 1988, 1994, and 1995).

h Units of $\mathrm{pCi} / \mathrm{L}$ will be reported by the analytical laboratory based on the activity of the tritium in the soil moisture. The PAL for tritium in soil is based on the UGTA Project limit of $400,000 \mathrm{pCi} / \mathrm{L}$ for discharge of water containing tritium to an infiltration basin/area (NNSA/NV, 2002b).

'Standard Test Method for Radiochemical Determination of Plutonium in Soil by Alpha Spectroscopy (ASTM, 2002).

jGeneral Radiochemistry and Routine Analytical Services Protocol (GRASP) (EG\&G Rocky Flats, 1991). The chemical yield only applies to plutonium, uranium and strontium.

${ }^{\mathrm{k}}$ Standard Test Method for Radiochemical Determination of Uranium Isotopes in Soil by Alpha Spectrometry (ASTM, 2000). 
Table 3-4

Analytical Requirements for Radionuclides for CAU 556

(Page 2 of 2)

\begin{tabular}{|c|c|c|c|c|c|c|}
\hline $\begin{array}{c}\text { Parameterl } \\
\text { Analyte }\end{array}$ & Matrix & $\begin{array}{c}\text { Analytical } \\
\text { Method }\end{array}$ & $\begin{array}{c}\text { Metectable } \\
\text { Concentration } \\
(\mathrm{MDC})^{\mathrm{a}}\end{array}$ & $\begin{array}{c}\text { PAL } \\
(\mathrm{M}, \mathrm{c}\end{array}$ & $\begin{array}{c}\text { Laboratory } \\
\text { Precision } \\
\text { (RPD) }\end{array}$ & $\begin{array}{c}\text { Percent } \\
\text { Recovery } \\
\text { (\%R) }\end{array}$ \\
\hline
\end{tabular}

ASTM = American Society for Testing and Materials HASL $=$ Health and Safety Laboratory MDC = Minimum detectable concentration $\mathrm{mrem} / \mathrm{yr}=$ Millirem per year
ND $=$ Normalized difference

$\mathrm{PAL}=$ Preliminary action level

$\mathrm{pCi} / \mathrm{g}=$ Picocuries per gram

$\mathrm{pCi} / \mathrm{L}=$ Picocuries per liter 
Table 3-5

Analytical Requirements for Chemical COPCs for CAU 556

(Page 1 of 2)

\begin{tabular}{|c|c|c|c|c|c|}
\hline Parameter/Analyte & $\begin{array}{c}\text { Medium } \\
\text { or } \\
\text { Matrix }\end{array}$ & $\begin{array}{l}\text { Analytical } \\
\text { Method }\end{array}$ & $\begin{array}{c}\text { Minimum } \\
\text { Detectable } \\
\text { Concentration } \\
\text { (MDC) }\end{array}$ & $\begin{array}{c}\text { Laboratory } \\
\text { Precision (RPD) }^{\mathrm{a}}\end{array}$ & $\begin{array}{c}\text { Percent } \\
\text { Recovery } \\
\text { (\%R) }^{\mathrm{b}}\end{array}$ \\
\hline \multicolumn{6}{|c|}{ Organics } \\
\hline \multirow{2}{*}{ Total Volatile Organic Compounds } & Aqueous & \multirow{2}{*}{$8260 B^{c}$} & \multirow{6}{*}{$\begin{array}{l}\text { Parameter-specific } \\
\text { EQLs }{ }^{\mathrm{d}, \mathrm{f}}\end{array}$} & \multirow{8}{*}{ Lab-specific $^{\mathrm{e}}$} & \multirow{8}{*}{ Lab-specific $^{e}$} \\
\hline & Soil & & & & \\
\hline \multirow{2}{*}{$\begin{array}{l}\text { Total Semivolatile Organic } \\
\text { Compounds }\end{array}$} & Aqueous & \multirow{2}{*}{$8270 C^{c}$} & & & \\
\hline & Soil & & & & \\
\hline \multirow{2}{*}{ Polychlorinated Biphenyls } & Aqueous & \multirow{2}{*}{$8082^{c}$} & & & \\
\hline & Soil & & & & \\
\hline $\begin{array}{l}\text { Total Petroleum Hydrocarbons- } \\
\text { Gasoline-Range Organics }\end{array}$ & Soil & $\begin{array}{c}8015 B \\
\text { modified }^{c}\end{array}$ & $0.5 \mathrm{mg} / \mathrm{kg}^{\mathrm{g}}$ & & \\
\hline $\begin{array}{l}\text { Total Petroleum Hydrocarbons- } \\
\text { Diesel-Range Organics }\end{array}$ & Soil & $\begin{array}{c}\text { 8015B } \\
\text { modified }^{\mathrm{c}}\end{array}$ & $25 \mathrm{mg} / \mathrm{kg}^{\mathrm{g}}$ & & \\
\hline \multicolumn{6}{|c|}{ Inorganics } \\
\hline \multicolumn{6}{|c|}{ Total RCRA Metals, plus Beryllium } \\
\hline \multirow{2}{*}{ Arsenic } & Aqueous & $6010 \mathrm{~B}^{\mathrm{C}}$ & $0.01 \mathrm{mg} / \mathrm{L}^{\mathrm{g}, \mathrm{h}}$ & \multirow{10}{*}{$\begin{array}{c}\text { RPD }=30 \% \\
\text { (aqueous) and } 35 \% \\
\text { (soil) when }>5 \times C R D L \\
\text { and absolute } \\
\text { difference }<\text { CRDL } \\
\text { (water) }<2 \times \text { CRDL } \\
\text { (soil) when }<5 \times C R D L\end{array}$} & \multirow{6}{*}{$\begin{array}{c}\text { Matrix Spike } \\
\text { Recovery } \\
\text { at } \\
75-125^{\mathrm{h}}\end{array}$} \\
\hline & Soil & $6010 B^{c}$ & $1 \mathrm{mg} / \mathrm{kg}^{\mathrm{g}, \mathrm{h}}$ & & \\
\hline \multirow{2}{*}{ Barium } & Aqueous & $6010 B^{c}$ & $0.20 \mathrm{mg} / \mathrm{L}^{\mathrm{g}, \mathrm{h}}$ & & \\
\hline & Soil & $6010 B^{c}$ & $20 \mathrm{mg} / \mathrm{kg}^{\mathrm{g}, \mathrm{h}}$ & & \\
\hline \multirow{2}{*}{ Beryllium } & Aqueous & $6010 B^{c}$ & $0.005 \mathrm{mg} / \mathrm{L}^{\mathrm{g}, \mathrm{h}}$ & & \\
\hline & Soil & $6010 \mathrm{~B}^{\mathrm{c}}$ & $0.5 \mathrm{mg} / \mathrm{kg}^{\mathrm{g}, \mathrm{h}}$ & & \\
\hline \multirow{2}{*}{ Cadmium } & Aqueous & $6010 B^{c}$ & $0.005 \mathrm{mg} / \mathrm{L}^{\mathrm{g}, \mathrm{h}}$ & & \multirow{4}{*}{$\begin{array}{c}\text { Laboratory Control } \\
\text { Sample Recovery } \\
\text { at } \\
80-120^{h}\end{array}$} \\
\hline & Soil & $6010 B^{c}$ & $0.5 \mathrm{mg} / \mathrm{L}^{\mathrm{g}, \mathrm{h}}$ & & \\
\hline \multirow{2}{*}{ Chromium } & Aqueous & $6010 B^{c}$ & $0.01 \mathrm{mg} / \mathrm{L}^{\mathrm{g}, \mathrm{h}}$ & & \\
\hline & Soil & $6010 B^{c}$ & $1 \mathrm{mg} / \mathrm{kg}^{\mathrm{g}, \mathrm{h}}$ & & \\
\hline
\end{tabular}


Table 3-5

Analytical Requirements for Chemical COPCs for CAU 556

(Page 2 of 2)

\begin{tabular}{|c|c|c|c|c|c|}
\hline Parameter/Analyte & $\begin{array}{l}\text { Medium } \\
\text { or } \\
\text { Matrix }\end{array}$ & $\begin{array}{l}\text { Analytical } \\
\text { Method }\end{array}$ & $\begin{array}{c}\text { Minimum } \\
\text { Detectable } \\
\text { Concentration } \\
\text { (MDC) }\end{array}$ & $\begin{array}{c}\text { Laboratory } \\
\text { Precision (RPD) }\end{array}$ & $\begin{array}{c}\text { Percent } \\
\text { Recovery } \\
(\% R)^{b}\end{array}$ \\
\hline \multirow{2}{*}{ Lead } & Aqueous & $6010 B^{c}$ & $0.003 \mathrm{mg} / \mathrm{L}^{\mathrm{g}, \mathrm{h}}$ & \multirow{8}{*}{$\begin{array}{c}\text { RPD }=30 \% \\
\text { (aqueous) and } 35 \% \\
\text { (soil) when }>5 \times C R D L \\
\text { and absolute } \\
\text { difference }<\text { CRDL } \\
\text { (water) }<2 \times \text { CRDL } \\
\text { (soil) when }<5 \times \text { CRDL }\end{array}$} & \multirow{5}{*}{$\begin{array}{c}\text { Matrix Spike } \\
\text { Recovery } \\
\text { at } \\
75-125^{\mathrm{h}}\end{array}$} \\
\hline & Soil & $6010 B^{c}$ & $0.3 \mathrm{mg} / \mathrm{kg}^{\mathrm{g}, \mathrm{h}}$ & & \\
\hline \multirow{2}{*}{ Mercury } & Aqueous & $7470 A^{c}$ & $0.0002 \mathrm{mg} / \mathrm{L}^{\mathrm{g}, \mathrm{h}}$ & & \\
\hline & Soil & $7471 A^{c}$ & $0.1 \mathrm{mg} / \mathrm{kg}^{\mathrm{g}, \mathrm{h}}$ & & \\
\hline \multirow{2}{*}{ Selenium } & Aqueous & $6010 B^{c}$ & $0.005 \mathrm{mg} / \mathrm{L}^{\mathrm{g}, \mathrm{h}}$ & & \\
\hline & Soil & $6010 B^{c}$ & $0.5 \mathrm{mg} / \mathrm{kg}^{\mathrm{g}, \mathrm{h}}$ & & \multirow{3}{*}{$\begin{array}{c}\text { Laboratory Control } \\
\text { Sample Recovery } \\
\text { at } \\
80-120^{\mathrm{h}}\end{array}$} \\
\hline \multirow{2}{*}{ Silver } & Aqueous & $6010 B^{c}$ & $0.01 \mathrm{mg} / \mathrm{L}^{\mathrm{g}, \mathrm{h}}$ & & \\
\hline & Soil & $6010 B^{c}$ & $1 \mathrm{mg} / \mathrm{kg}^{\mathrm{g}, \mathrm{h}}$ & & \\
\hline
\end{tabular}

See Table 3-4 for the analytical requirements for radionuclides.

${ }^{\mathrm{a}}$ Precision is estimated from the relative percent difference (RPD) of the laboratory or field duplicates MSD and LCSD are spiked. It is calculated by: $R P D=100 \times\left(\left|A_{1}-A_{2}\right|\right) /\left[\left(A_{1}+A_{2}\right) / 2\right]$, where $A_{1}=$ Concentration of the parameter in the initial sample aliquot, $A_{2}=$ Concentration of the parameter in the duplicate sample aliquot.

${ }^{b}$ Accuracy is assessed from the percent recovery (\%R) of parameters spiked into a blank or sample matrix of interest, or from the recovery of surrogate compounds spiked into each sample. The recovery of each spiked parameter is calculated by: $\% R=100 \times\left(A_{s}-A_{u} / A_{n}\right)$, where $A_{s}=$ Concentration of the parameter in the spiked sample, $A_{u}=$ Concentration of the parameter in the unspiked sample, $A_{n}=$ Concentration increase that should result from spiking the sample.

${ }^{\mathrm{c}}$ Test Methods for Evaluating Solid Waste Physical/Chemical Methods, 3rd Edition, Parts 1-4, (SW-846) CD-ROM, Washington, DC (EPA,1996)

${ }^{d}$ Estimated Quantitation Limit as given in SW-846 (EPA, 1996).

${ }^{\mathrm{e}} \mathrm{RPD}$ and \%R Performance Criteria are developed and generated in-house by the laboratory according to approved laboratory procedures.

${ }^{\dagger}$ Contract Laboratory Program Statement of Work for Organic Analysis (EPA, 2003).

IIndustrial Sites Quality Assurance Project Plan (NNSA/NV, 2002a).

${ }^{\mathrm{h}}$ EPA Contract Laboratory Program Statement of Work for Inorganic Analysis (EPA, 1995).

CRDL = Contract-required detection limit

$\mathrm{EQL}=$ Estimated quantitation limit

LCSD = Laboratory control sample duplicate

MSD = Matrix spike duplicate $\mathrm{mg} / \mathrm{kg}=$ Milligrams per kilogram

$\mathrm{mg} / \mathrm{L}=$ Milligrams per liter

RCRA = Resource Conservation and Recovery Act

$\mathrm{RPD}=$ Relative percent difference 


\subsection{Field Investigation}

This section describes of the activities to be conducted to gather and document CAU 556 field investigation information.

\subsection{Technical Approach}

The information necessary to satisfy the DQO data needs will be generated for each CAU 556 CAS by collecting and analyzing samples generated during a field investigation. The presence and nature of contamination at the CAU 556 CASs will be evaluated using a judgmental approach.

If there is a waste present that has the potential to release significant contamination into site environmental media, if released, that waste will be sampled. If it is determined that a COC is present at any CAS, that CAS will be further addressed by determining the extent of contamination before evaluating corrective action alternatives.

Because this CAIP only addresses contamination originating from the CAU, it may be necessary to distinguish overlapping contamination originating from other sources. For example, widespread surface radiological contamination originating from atmospheric tests will not be addressed in the CAU 556 investigation. To determine whether contamination is from the CAU or from other sources, soil samples may be collected from background locations at selected CASs.

Modifications to the investigative strategy may be required should unexpected field conditions be encountered at any CAS. Significant modifications shall be justified and documented before implementation. If an unexpected condition indicates that conditions are significantly different than the corresponding CSM, the activity will be rescoped and the identified decision-makers will be notified.

\subsection{Field Activities}

Field activities at CAU 556 include site preparation, sample location selection, and sample collection activities. 


\subsubsection{Site Preparation Activities}

Site preparation activities conducted by the NTS management and operating contractor before the investigation may include, but not be limited to: relocation or removal of surface debris, equipment, and structures; constructing hazardous waste accumulation areas (HWAAs) and site exclusion zones; providing sanitary facilities; constructing decontamination facilities; and temporarily moving staged equipment.

Before mobilization for collecting investigation samples, the following preparatory activities will also be performed:

- Radiological surveys of all CASs.

- Visual surveys at all CASs within CAU 556 to identify any staining, discoloration, disturbance of native soils, or any other indication of potential contamination.

\subsubsection{Sample Location Selection}

At the CAU 556 CASs, biasing factors (including field-screening results) will be used to select the most appropriate samples from a particular location for submittal to the analytical laboratory. Biasing factors to be used for selection of sampling locations are listed in Section A.5.2.1. As biasing factors are identified and used for selection of sampling locations, they will be recorded in the appropriate field documents.

The CAS-specific sampling strategy and the estimated locations of biased samples for each CAS are presented in Appendix A. The number, location, and spacing of step-outs may be modified by the Task Manager or Site Supervisor, as warranted by site conditions to achieve DQO criteria stipulated in Appendix A. Where sampling locations are modified by the Task Manager or Site Supervisor, the justification for these modifications will be documented in the field logbook. 


\subsubsection{Sample Collection}

The CAU 556 sampling program will consist of the following activities:

- Collect and analyze samples from locations as described in this section.

- Collect required QC samples.

- Collect waste management samples.

- Collect soil samples from background locations, if necessary.

- Perform radiological characterization surveys of construction materials and debris as necessary for disposal purposes.

- Record Global Positioning System coordinates for each environmental sample location.

Decision I surface soil samples ( 0 to $0.5 \mathrm{ft}$ bgs) will be collected. If biasing factors are present in soils below locations where Decision I samples were collected, subsurface Decision I soil samples will also be collected by hand augering, backhoe excavation, direct-push, or drilling techniques, as appropriate. Decision I subsurface soil samples will collected at depth intervals selected by the Task Manager or Site Supervisor based on biasing factors to a depth where the biasing factors are no longer present.

Decision II sampling will consist of further defining the extent of contamination where COCs have been confirmed. Step-out (Decision II) sampling locations at each CAS will be selected based on the CSM, biasing factors, field-screening results, existing data, and the outer boundary sample locations where COCs were detected. In general, step-out sample locations will be arranged in a triangular pattern around areas containing a COC at distances based on site conditions, COC concentrations, process knowledge, and biasing factors. If COCs extend beyond step-out locations, additional Decision II samples will be collected from locations further from the source. If a spatial boundary is reached, the CSM proves to be inadequate, or the Site Supervisor determines that sampling needs to be re-evaluated, then work will be temporarily suspended, NDEP notified, and the investigation strategy re-evaluated. A minimum of one analytical result less than the action level from each lateral and vertical direction will be required to define the extent of COC contamination. The lateral and vertical extent of COCs will only be established based on validated laboratory analytical results (i.e., not field screening). 


\subsubsection{Sample Management}

The laboratory requirements (i.e., detection limits, precision, and accuracy requirements) to be used when analyzing the COPCs are presented in Tables 3-4 and 3-5. The analytical program for each CAS is presented in Table 3-1. All sampling activities and QC requirements for field and laboratory environmental sampling will be conducted in compliance with the Industrial Sites QAPP (NNSA/NV, 2002a) and other applicable, approved procedures.

\subsection{Safety}

A site-specific health and safety document will be prepared and approved before the field effort. As required by the DOE Integrated Safety Management System (ISMS) (DOE/NV, 1997), this document outlines the requirements for protecting the health and safety of the workers and the public. The ISMS program requires that site personnel shall reduce or eliminate the possibility of injury, illness, or accidents, and to protect the environment during project activities. The following safety issues will be taken into consideration when evaluating the hazards and associated control procedures for field activities:

- Potential hazards to site personnel and the public include, but are not limited to: radionuclides, chemicals (e.g., heavy metals, semivolatile organic compounds [SVOCs], VOCs, and TPH), adverse and rapidly changing weather, remote location, and motor vehicle and heavy equipment operations.

- Proper training of all site personnel to recognize and mitigate the anticipated hazards.

- Work controls to reduce or eliminate the hazards including engineering controls, substitution of less hazardous materials, and use of appropriate personal protective equipment (PPE).

- Occupational exposure monitoring to prevent overexposures to hazards such as radionuclides, chemicals, and physical agents (e.g., heat, cold, and high wind).

- Radiological surveying for alpha/beta and gamma emitters to minimize and/or control personnel exposures; use of the "as-low-as-reasonably-achievable" principle when addressing radiological hazards.

- Emergency and contingency planning to include medical care and evacuation, decontamination, spill control measures, and appropriate notification of project management. The same principles apply to emergency communications. 
- If presumed asbestos-containing material is identified (CFR, 2003b; NAC, 2006a), it will be inspected and/or samples collected by trained personnel.

\subsection{Site Restoration}

Following completion of CAI and waste management activities, the following actions will be conducted before closure of the site Real Estate/Operations Permit:

- Removal of all equipment, wastes, debris, and CAI associated materials.

- Removal of all signage and fencing (unless part of a corrective action).

- Site grading to pre-investigation condition (unless changed condition is necessary under a corrective action).

- Site inspection and certification that restoration activities have been completed. 


\subsection{Waste Management}

Management of IDW will be based on regulatory requirements, field observations, process knowledge, and laboratory results from CAU 556 investigation samples.

Disposable sampling equipment, PPE, and rinsate are considered potentially contaminated waste by virtue of contact with potentially contaminated media (e.g., soil) or potentially contaminated debris (e.g., construction materials). Therefore, sampling and analysis of IDW separate from analyses of site investigation samples may not be necessary for all IDW. However, if associated investigation samples are found to contain contaminants above regulatory levels, conservative estimates of total waste contaminant concentrations may be made based on the mass of the waste, the amount of contaminated media contained in the waste, and the maximum concentration of contamination found in the media. Direct samples of IDW may also be taken to support waste characterization.

Sanitary, hazardous, radioactive, and/or mixed waste, if generated, will be managed and disposed of in accordance with applicable DOE orders, U.S. Department of Transportation (DOT) regulations, state and federal waste regulations, and agreements and permits between DOE and NDEP.

\subsection{Waste Minimization}

Investigation activities are planned to minimize IDW generation. This will be accomplished by incorporating the use of process knowledge, visual examination, and/or radiological survey and swipe results. When possible, disturbed media (such as soil removed during trenching) or debris will be returned to its original location. Contained media (e.g., soil managed as waste) as well as other IDW will be segregated to the fullest extent possible to minimize generation of hazardous, radioactive, or mixed waste. Hazardous material used at the sites will be controlled to limit unnecessary generation of hazardous or mixed waste. Administrative controls, including decontamination procedures and waste characterization strategies, will minimize waste generated during investigations. 


\subsection{Potential Waste Streams}

Waste generated during the investigation activities will include the following potential waste streams:

- Personal protective equipment and disposable sampling equipment (e.g., plastic, paper, sample containers, aluminum foil, spoons, bowls)

- Decontamination rinsate

- Environmental media (e.g., soil)

- $\quad$ Surface debris in investigation area (e.g., rusted buckets)

- Field-screening waste (e.g., spent solvent, disposable sampling equipment, and/or PPE contaminated by field-screening activities)

\subsection{Investigation-Derived Waste Management}

The onsite management and ultimate disposition of IDW will be determined based on a determination of the waste type (e.g., sanitary, low-level, hazardous, hydrocarbon, mixed), or the combination of waste types. A determination of the waste type will be guided by several factors including, but not limited to: analytical results of samples directly or indirectly associated with the waste, historical site knowledge, waste generation process knowledge, field observations, field-monitoring/screening results, and/or radiological survey/swipe results.

Table 4-2 of the NV/YMP RadCon Manual (NNSA/NSO, 2004) shall be used to determine whether such materials may be declared nonradioactive. Onsite IDW management requirements by waste type are detailed in the following sections. Applicable waste management regulations and requirements are listed in Table 5-1. 
Table 5-1

Waste Management Regulations and Requirements

\begin{tabular}{|c|c|c|}
\hline Waste Type & Federal Regulation & Additional Requirements \\
\hline Solid (nonhazardous) & $\mathrm{N} / \mathrm{A}$ & $\begin{array}{c}\text { NRS }^{\mathrm{a}} 444.440-444.620 \\
\text { NAC }^{\mathrm{b}} 444.570-444.7499 \\
\text { NTS Landfill Permit SW13.097.04 } \\
\text { NTS Landfill Permit SW13.097.03 }\end{array}$ \\
\hline Liquid/Rinsate (nonhazardous) & N/A & $\begin{array}{l}\text { Water Pollution Control General Permit } \\
\text { GNEV93001, Rev. 3iii }\end{array}$ \\
\hline Hazardous & $\begin{array}{c}\text { RCRA }^{f}, \\
40 \text { CFR 260-282 }\end{array}$ & $\begin{array}{c}\text { NRS }^{a} 459.400-459.600 \\
\text { NAC }^{b} 444.850-444.8746 \\
\text { POC }^{g}\end{array}$ \\
\hline Low-Level Radioactive & N/A & DOE Orders and NTSWAC \\
\hline Mixed & $\begin{array}{c}\text { RCRA }^{f}, \\
40 \text { CFR 260-282 }\end{array}$ & $\begin{array}{l}\text { NTSWAC } \\
\text { POC }^{\mathrm{h}}\end{array}$ \\
\hline Hydrocarbon & $\mathrm{N} / \mathrm{A}$ & $\begin{array}{c}\text { NTS Landfill Permit SW13.097.02 } \\
\text { NAC }^{\text {b }} 445 a .2272\end{array}$ \\
\hline Polychlorinated Biphenyls & $\begin{array}{c}\text { TSCA }^{\mathrm{j}} \\
40 \text { CFR } 761\end{array}$ & $\begin{array}{l}\text { NRS }^{a} 459.400-459.600 \\
N^{b} C^{b} 444.940-444.9555\end{array}$ \\
\hline Asbestos & $\begin{array}{c}\text { TSCA } \\
40 \text { CFR } 763\end{array}$ & $\begin{array}{l}\text { NRS }^{a} 618.750-618.840 \\
\text { NAC }^{b} 444.965-444.976\end{array}$ \\
\hline
\end{tabular}

${ }^{\mathrm{a}}$ Nevada Revised Statutes (NRS, 2005a, b, c)

${ }^{\mathrm{b}}$ Nevada Administrative Code (NAC, 2006a, d)

cArea 23 Class II Solid Waste Disposal Site (NDEP, 1997a)

${ }^{d}$ Area 9 Class III Solid Waste Disposal Site (NDEP, 1997c)

${ }^{\mathrm{e}}$ Nevada Test Site Sewage Lagoons (NDEP, 2005)

${ }^{\mathrm{f}}$ Resource Conservation and Recovery Act (CFR, 2006)

${ }^{9}$ Nevada Test Site Performance Objective for the Certification of Nonradioactive Hazardous Waste (BN, 1995)

${ }^{\mathrm{h}}$ Nevada Test Site Waste Acceptance Criteria, Rev. 6 (NNSA/NSO, 2005)

'Area 6 Class III Solid Waste Disposal Site for Hydrocarbon Burdened Soils (NDEP, 1997b)

${ }^{\mathrm{j}}$ Toxic Substance Control Act (CFR, 2003a, b)

CFR $=$ Code of Federal Regulations

DOE $=$ U.S. Department of Energy

N/A = Not applicable

NAC $=$ Nevada Administrative Code

NRS $=$ Nevada Revised Statutes

NTS = Nevada Test Site

NTSWAC $=$ Nevada Test Site Waste Acceptance Criteria

$\mathrm{POC}=$ Performance Objective for the Certification of Nonradioactive Hazardous Waste

RCRA = Resource Conservation and Recovery Act

TSCA $=$ Toxic Substance Control Act 


\subsubsection{Sanitary Waste}

Sanitary IDW generated at each CAS will be collected, managed, and disposed of in accordance with the sanitary waste management regulations and the permits for operation of the NTS 10c Industrial Waste Landfill.

Office trash and lunch waste will be placed in the dumpster to be transported to the sanitary landfill for disposal. Sanitary IDW generated at each CAS will only be collected in plastic bags, sealed, labeled with the CAS number from each site in which it was generated, and dated. The waste will then be placed in a roll-off box located in Mercury, or other approved roll-off box location. The number of bags of sanitary IDW will be counted as they are placed in the roll-off box, noted in a log, and documented in the Field Activity Daily Log (FADL). These logs will provide necessary tracking information for ultimate disposal in the 10c Industrial Waste Landfill.

\subsubsection{Low-Level Radioactive Waste}

Radiological swipe surveys and/or direct-scan surveys may be conducted on reusable sampling equipment and the PPE and disposable sampling equipment waste streams exiting a radiologically controlled area (RCA). This allows for the immediate segregation of radioactive waste from waste that may be unrestricted regarding radiological release. Removable contamination limits, as defined in Table 4-2 of the current version of the NV/YMP RadCon Manual (NNSA/NSO, 2004), will be used to determine whether such waste may be declared unrestricted regarding radiological release versus being declared radioactive waste. Direct sampling of the waste may be conducted to aid in determining whether a particular waste unit (e.g., drum of soil) contains low-level radioactive waste, as necessary. Waste that is determined to be below the values of Table 4-2, by direct radiological survey/swipe results or through process knowledge, will not be managed as potential radioactive waste but in accordance with the appropriate section of this document. Wastes in excess of Table 4-2 values managed as potential radioactive waste, and in accordance with this section, and any other applicable sections of this document.

Low-level radioactive waste, if generated, will be managed in accordance with the contractor-specific waste certification program plan, DOE orders, and the requirements of the current version of the Nevada Test Site Waste Acceptance Criteria (NTSWAC) (NNSA/NSO, 2005). Potential radioactive 
waste drums containing soil, PPE, disposable sampling equipment, and/or rinsate may be staged at a designated radioactive material area (RMA) or RCA when full or at the end of an investigation phase. The waste drums will remain at the RMA pending certification and disposal under NTSWAC requirements (NNSA/NSO, 2005).

\subsubsection{Hazardous Waste}

The CAU will have waste accumulation areas established according to the needs of the project. Satellite accumulation areas and HWAAs will be managed consistent with the requirements of federal and state regulations (CFR, 2006; NAC, 2006a and d). The HWAAs will be properly controlled for access, and will be equipped with spill kits and appropriate spill containment. Suspected hazardous wastes will be placed in DOT-compliant containers. All containerized hazardous waste will be handled, inspected, and managed in accordance with Title 40 Code of Federal Regulations (CFR) 265 Subpart I (CFR, 2006). These provisions include managing the waste in containers compatible with the waste type, and segregating incompatible waste types so that in the event of a spill, leak, or release, incompatible wastes shall not contact one another. The HWAAs will be covered under a site-specific emergency response and contingency action plan until such time that the waste is determined to be nonhazardous or all containers of hazardous waste have been removed from the storage area. Hazardous waste will be characterized in accordance with the requirement of Title 40 CFR 261 (CFR, 2006). Resource Conservation and Recovery Act-“listed” waste has not been identified; therefore, waste will be determined hazardous if it exhibits characteristics as listed in Title 40 CFR 261 (CFR, 2006), but is potentially present at CAS 25-60-03, based on previous sampling in an immediately adjacent CAS in 2003, and CAS 25-64-01 and CAS 06-20-04 based on reported usage when the CAS was in operation. Any waste determined to be hazardous will be managed and transported to a permitted treatment, storage, and disposal facility in accordance with RCRA and DOT requirements (CFR, 2006).

\subsubsection{Hydrocarbon Waste}

Hydrocarbon soil waste containing more than $100 \mathrm{mg} / \mathrm{kg}$ of TPH will be managed on site in a drum or other appropriate container until fully characterized. Hydrocarbon waste may be disposed of at a designated hydrocarbon landfill (NDEP, 1997b), an appropriate hydrocarbon waste management facility (e.g., recycling facility), or other method in accordance with State of Nevada regulations.

\section{UNCONTROLLED when Printed}




\subsubsection{Mixed Low-Level Waste}

Mixed waste, if generated, shall be managed and dispositioned according to the requirements of RCRA (CFR, 2006) or subject to agreements between NNSA/NSO and the State of Nevada, as well as DOE requirements for radioactive waste. The waste will be marked with the words "Hazardous Waste Pending Analysis and Radioactive Waste Pending Analysis.” Waste characterized as mixed will not be stored for a period of time that exceeds the requirements of RCRA unless subject to agreements between NNSA/NSO and the State of Nevada. The mixed waste shall be transported via an approved hazardous waste/radioactive waste transporter to the NTS transuranic waste storage pad for storage pending treatment or disposal. Mixed waste with hazardous waste constituent concentrations below Land Disposal Restrictions may be disposed of at the NTS Area 5 Radioactive Waste Management Site if the waste meets the requirements of the NTSWAC (NNSA/NSO, 2005), the NTS NDEP permit for a Hazardous Waste Management Facility (NEV HW0021 [NDEP, 2005]), and the RCRA Part B Permit Application for Hazardous Waste Management Activities (NNSA/NSO, 2005). Mixed waste constituent concentrations exceeding Land Disposal Restrictions will require development of a treatment and disposal plan under the requirements of the Mutual Consent Agreement between DOE and the State of Nevada (NDEP, 1995).

\subsubsection{Polychlorinated Biphenyls}

The management of PCBs is governed by the Toxic Substances Control Act (USC, 1976) and its implementing regulations at 40 CFR 761 (CFR, 2003a). Polychlorinated biphenyl contamination may be found as a sole contaminant or in combination with any of the types of waste discussed in this document. For example, PCBs may be a co-contaminant in soil that contains a RCRA “characteristic” waste (PCB/hazardous waste), or in soil that contains radioactive wastes (PCB/radioactive waste), or in mixed waste (PCB/radioactive/hazardous waste). The IDW will initially be evaluated using analytical results for media samples from the investigation. If any type of PCB waste is generated, it will be managed according to 40 CFR 761 (CFR, 2003a) as well as state of Nevada requirements, (NAC, 2006a) guidance, and agreements with NNSA/NSO. 


\subsection{Management of Specific Waste Streams}

\subsubsection{Personal Protective Equipment}

Personal protective equipment and disposable sampling equipment will be visually inspected for stains, discoloration, and gross contamination as the waste is generated, and also evaluated for radiological contamination. Staining and/discoloration will be assumed to be the result of contact with potentially contaminated media such as soil, sludge, or liquid. Gross contamination is the visible contamination of an item (e.g., clumps of soil/sludge on a sampling spoon or free liquid smeared on a glove). While gross contamination can often be removed through decontamination methods, removal of gross contamination from small items, such as gloves or booties is not typically conducted. Any IDW that meets this description will be segregated and managed as potentially "characteristic" hazardous waste. This segregated population of waste will be either: (1) assigned the characterization of the soil/sludge that was sampled, (2) sampled directly, or (3) undergo further evaluation using the soil/sludge sample results to determine how much soil/sludge would need to be present in the waste to exceed regulatory levels. Waste that is determined to be hazardous will be entered into an approved waste management system, where it will be managed and dispositioned according to RCRA requirements or subject to agreements between NNSA/NSO and the State of Nevada. The PPE and equipment that is not visibly stained, discolored, or grossly contaminated and that is within the radiological free-release criteria, will be managed as nonhazardous sanitary waste.

\subsubsection{Management of Decontamination Rinsate}

Rinsate at CAU 556 will not be considered hazardous waste unless there is evidence that the rinsate may display a RCRA characteristic. Evidence may include such things as the presence of a visible sheen, $\mathrm{pH}$, or association with equipment/materials used to respond to a release/spill of a hazardous waste/substance. Decontamination rinsate that is potentially hazardous (using associated sample results and/or process knowledge) will be managed as characteristic hazardous waste (CFR, 2006). The regulatory status of the potentially hazardous rinsate will be determined through the application of associated sample results or through direct sampling. If the associated samples do not indicate the presence of hazardous constituents, then the rinsate will be considered nonhazardous. 
The disposal of nonhazardous rinsate will be consistent with guidance established in current NNSA/NSO Fluid Management Plans for the NTS as follows:

- $\quad$ Rinsate that is determined to be nonhazardous and contaminated to less than 5x Safe Drinking Water Standards (SDWS) is not restricted as to disposal. Nonhazardous rinsate, contaminated at 5x to 10x SDWS, will be disposed of in an established infiltration basin or solidified and disposed of as sanitary waste or low-level waste in accordance with the respective sections of this document.

- Nonhazardous rinsate, contaminated at greater than 10x SDWS, will be disposed of in a lined basin or solidified and disposed of as sanitary waste or low-level waste in accordance with the respective sections of this document.

\subsubsection{Management of Soil}

This waste stream consists of soil removed for disposal during soil sampling, excavation, and/or drilling and will be characterized based on laboratory analytical results from representative locations. If the soil is determined to potentially contain COCs, the material will be managed on site or containerized for transportation to an appropriate disposal site.

Onsite management of the waste soil will be allowed only if it is managed within an area of concern and it is appropriate to defer the management of the waste until the final remediation of the site. If this option is chosen, the waste soil shall be protected from run-on and run-off using appropriate protective measures based on the type of contaminant(s) (e.g., covered with plastic and bermed).

Management of soil waste for disposal consists of placing the waste in containers, labeling the containers, temporarily storing the containers until shipped, and shipping the waste to a disposal site. The containers, labels, management of stored waste, transport to the disposal site, and disposal shall be appropriate for the type of waste (e.g., hazardous, hydrocarbon, mixed).

Note that soils returned to a borehole or excavation in the same approximate location from which it originated is not considered to be a waste.

\subsubsection{Management of Debris}

This waste stream can vary depending on site conditions. Debris that requires removal for the investigation activities (soil sampling, excavation, and/or drilling) must be characterized for proper 
management and disposition. Historical site knowledge, waste generation process knowledge, field observations, field-monitoring/screening results, radiological survey/swipe results and/or the analytical results of samples directly or indirectly associated with the waste may be used to characterized the debris. Debris will be visually inspected for stains, discoloration, and gross contamination. Debris may be deemed reusable, recyclable, sanitary waste, hazardous waste, PCB waste, or low-level waste. Waste that is not sanitary will be entered into an approved waste management system, where it will be managed and dispositioned according to federal, state requirements, and agreements between NNSA/NSO and the State of Nevada. The debris will be managed on site by berming and covering next to the excavation, placement in a container(s), or left on the footprint of the CAS and its disposition deferred until implementation of corrective action at the site, where it may be disposed of as a best management practice.

\subsubsection{Field-Screening Waste}

The use of field test kits and/or instruments may result in the generation of small quantities of hazardous wastes. If hazardous waste is produced by field screening, it will be segregated from other IDW and managed in accordance with the hazardous waste regulations (CFR, 2006). For sites where field-screening samples contain radioactivity above background levels, field-screening methods that have the potential to generate hazardous waste will not be used, thus avoiding the potential to generate mixed waste. In the event a mixed waste is generated, the waste will be managed in accordance with Section 5.3.5 of this document. 


\subsection{Quality Assurance/Quality Control}

The overall objective of the characterization activities described in this CAIP is to collect accurate and defensible data to support the selection and implementation of a closure alternative for each CAU 556 CAS. Sections 6.1 and 6.2 discuss the collection of required QC samples in the field and QA requirements for laboratory/analytical data to achieve closure. Unless otherwise stated in this CAIP or required by the results of the DQO process (Appendix A), this investigation will adhere to the Industrial Sites QAPP (NNSA/NV, 2002a).

\subsection{Quality Control Sampling Activities}

Field QC samples will be collected in accordance with established procedures. Field QC samples are collected and analyzed to aid in determining the validity of environmental sample results. The number of required QC samples depends on the types and number of environmental samples collected. As determined for this investigation in the DQO process, the minimum frequency of collecting and analyzing QC samples include:

- $\quad$ Trip blanks (1 per sample cooler containing VOC environmental samples)

- Equipment rinsate blanks (1 per sampling event for each type of decontamination procedure)

- $\quad$ Source blanks (1 per lot of uncharacterized source material that contacts sampled media)

- Field duplicates (1 per 20 environmental samples or 1 per CAS per matrix, if less than 20 collected)

- $\quad$ Field blanks (1 per CAS)

- Laboratory QC samples (1 per 20 environmental samples or 1 per CAS per matrix, if less than 20 collected)

Additional QC samples may be submitted based on site conditions at the discretion of the Task Manager or Site Supervisor. Field QC samples shall be analyzed using the same analytical procedures implemented for associated environmental samples. Additional details regarding field QC samples are available in the Industrial Sites QAPP (NNSA/NV, 2002a). 


\subsection{Laboratory/Analytical Quality Assurance}

As stated in the DQOs (Appendix A) and except where noted, criteria for the investigation require laboratory analytical quality data be used for making critical decisions. Rigorous QA/QC will be implemented for all laboratory samples including documentation, data verification and validation of analytical results, and an assessment of DQIs as they relate to laboratory analysis.

\subsubsection{Data Validation}

Data verification and validation will be performed in accordance with the Industrial Sites QAPP (NNSA/NV, 2002a), except where otherwise stipulated in this CAIP. All chemical and radiological laboratory data from samples that are collected and analyzed will be evaluated for data quality according to company-specific procedures. The data will be reviewed to ensure that all suspected samples were appropriately collected, analyzed, and the results passed data validation criteria. Validated data, including estimated data (i.e., J-qualified), will be assessed to determine whether they meet the DQO requirements of the investigation and the performance criteria for the DQIs. The results of this assessment will be documented in the Corrective Action Decision Document (CADD). If the DQOs were not met, corrective actions will be evaluated, selected, and implemented (e.g., refine CSM or resample to fill data gaps).

\subsubsection{Data Quality Indicators}

The DQIs are qualitative and quantitative descriptors used in interpreting the degree of data acceptability or utility. Data quality indicators are used to evaluate the entire measurement system and laboratory measurement processes (i.e., analytical method performance) as well as to evaluate individual analytical results (i.e., parameter performance). The data quality and usability used to make DQO decisions will be assessed based on the following DQIs:

- Precision

- Accuracy/bias

- Representativeness

- Comparability

- Completeness

- Sensitivity 
Table 6-1 provides the established analytical method/measurement system performance criteria for each of the DQIs and the potential impacts to the decision if criteria are not met. The following subsections discuss each of the DQIs that will be used to assess the laboratory data quality. Due to changes in analytical methodology and changes in analytical laboratory contracts, criteria for precision and accuracy in Tables 3-4 and 3-5 that vary from corresponding information in the QAPP will supersede the QAPP (NNSA/NV, 2002a).

Table 6-1

Laboratory and Analytical Performance Criteria for CAU 556 Data Quality Indicators

\begin{tabular}{|c|c|c|}
\hline $\begin{array}{l}\text { Data Quality } \\
\text { Indicator }\end{array}$ & Performance Metric & $\begin{array}{l}\text { Potential Impact on Decision } \\
\text { If Performance Metric Not Met }\end{array}$ \\
\hline Precision & $\begin{array}{l}\text { At least } 80 \% \text { of the sample results for each } \\
\text { measured contaminant are not qualified for } \\
\text { precision based on the criteria for each analytical } \\
\text { method-specific and laboratory-specific criteria } \\
\text { presented in Section } 6.2 .3 \text {, or for the field } \\
\text { duplicate criteria of } 80 \% \text { RPD or } 2 \% \text { ND. }\end{array}$ & $\begin{array}{l}\text { If the performance metric is not met, the } \\
\text { affected analytical results from each } \\
\text { affected CAS will be assessed to determine } \\
\text { whether there is sufficient confidence in } \\
\text { analytical results to use the data in making } \\
\text { DQO decisions. }\end{array}$ \\
\hline Accuracy & $\begin{array}{l}\text { At least } 80 \% \text { of the sample results for each } \\
\text { measured contaminant are not qualified for } \\
\text { accuracy based on the method-specific and } \\
\text { laboratory-specific criteria presented in } \\
\text { Section } 6.2 .4 \text {. }\end{array}$ & $\begin{array}{l}\text { If the performance metric is not met, the } \\
\text { affected analytical results from each } \\
\text { affected CAS will be assessed to determine } \\
\text { whether there is sufficient confidence in } \\
\text { analytical results to use the data in making } \\
\text { DQO decisions. }\end{array}$ \\
\hline Sensitivity & $\begin{array}{l}\text { Minimum detectable concentrations are less than } \\
\text { or equal to respective FALs. }\end{array}$ & $\begin{array}{l}\text { Cannot determine whether COCs are } \\
\text { present or migrating at levels of concern. }\end{array}$ \\
\hline Comparability & $\begin{array}{l}\text { Sampling, handling, preparation, analysis, } \\
\text { reporting, and data validation are performed } \\
\text { using standard methods and procedures. }\end{array}$ & $\begin{array}{l}\text { Inability to combine data with data obtained } \\
\text { from other sources and/or inability to } \\
\text { compare data to regulatory action levels. }\end{array}$ \\
\hline Representativeness & $\begin{array}{l}\text { Samples contain contaminants at concentrations } \\
\text { present in the environmental media from which } \\
\text { they were collected. }\end{array}$ & $\begin{array}{l}\text { Analytical results will not represent true site } \\
\text { conditions. Inability to make appropriate } \\
\text { DQO decisions. }\end{array}$ \\
\hline Completeness & $\begin{array}{l}80 \% \text { of the CAS-specific COPCs have valid } \\
\text { results. } \\
100 \% \text { of CAS-specific targeted contaminants } \\
\text { have valid results. }\end{array}$ & $\begin{array}{l}\text { Cannot support/defend decision on whether } \\
\text { COCs are present. }\end{array}$ \\
\hline Extent Completeness & $\begin{array}{l}100 \% \text { of COCs used to define extent have valid } \\
\text { results. }\end{array}$ & $\begin{array}{l}\text { Extent of contamination cannot be } \\
\text { determined accurately. }\end{array}$ \\
\hline $\begin{array}{l}\text { Clean Closure } \\
\text { Completeness }\end{array}$ & $\begin{array}{l}100 \% \text { of targeted contaminants have valid } \\
\text { results. }\end{array}$ & $\begin{array}{l}\text { Cannot determine whether COCs remain in } \\
\text { soil. }\end{array}$ \\
\hline
\end{tabular}

CAS $=$ Corrective action site $\mathrm{COC}=$ Contaminant of concern COPC = Contaminant of potential concern $\mathrm{DQO}=$ Data quality objective
$F A L=$ Final action level

ND $=$ Normalized difference

$\mathrm{RPD}=$ Relative percent difference 


\subsubsection{Precision}

Precision is a measure of the repeatability of the analysis process from sample collection through analysis results. It is used to assess the variability between two equal samples.

Determinations of precision will be made for field duplicate samples and laboratory duplicate samples. Field duplicate samples will be collected simultaneously with samples from the same source under similar conditions in separate containers. The duplicate sample will be treated independently of the original sample in order to assess field impacts and laboratory performance on precision through a comparison of results. Laboratory precision is evaluated as part of the required laboratory internal QC program to assess performance of analytical procedures. The laboratory sample duplicates are an aliquot (subset) of a field sample generated in the laboratory. They are not a separate sample but a split (portion) of an existing sample. Typically, laboratory duplicate QC samples may include matrix spike duplicate (MSD) and laboratory control sample (LCS) duplicate samples for organic, inorganic, and radiological analyses.

Precision is a quantitative measure used to assess overall analytical method and field-sampling performance as well as to assess the need to "flag" (qualify) individual parameter results when corresponding QC sample results are not within established control limits.

The criteria used for the assessment of chemical precision when both results are greater than or equal to $5 \mathrm{x}$ reporting limit (RL) is 20 and 35 percent for aqueous and soil samples, respectively. When either result is less than $5 x \mathrm{RL}$, a control limit of $\pm 1 \mathrm{x} R$ and $\pm 2 \mathrm{x} R$ for aqueous and soil samples, respectively, is applied to the absolute difference.

The criteria used for the assessment of radiological precision when both results are greater than or equal to $5 \mathrm{x}$ MDC is 20 and 35 percent for aqueous and soil samples, respectively. When either result is less than $5 \mathrm{x}$ MDC, the normalized difference (ND) should be between -2 and +2 for aqueous and soil samples. The parameters to be used for assessment of precision for duplicates are listed in Table 3-5.

Any values outside the specified criteria do not necessarily result in the qualification of analytical data. It is only one factor in making an overall judgment about the quality of the reported analytical results. The performance metric for assessing the DQI of precision on DQO decisions (Table 6-1) is 
that, for each measured contaminant, at least 80 percent of sample results are not qualified due to duplicates that exceed criteria. If this performance is not met, an assessment will be conducted on DQO decision impacts that are specific to affected contaminants and to CASs in the investigation report.

\subsubsection{Accuracy}

Accuracy is a measure of the closeness of an individual measurement to the true value. It is used to assess the performance of laboratory measurement processes.

Accuracy is determined by analyzing a reference material of known parameter concentration or by re-analyzing a sample to which a material of known concentration or amount of parameter has been added (spiked). Accuracy will be evaluated based on results from three types of spiked samples: (1) matrix spike (MS), (2) LCS, and (3) surrogates (organics). The LCS sample is analyzed with the field samples using the same sample preparation, reagents, and analytical methods employed for the samples. One LCS will be prepared with each batch of samples for analysis by a specific measurement.

The criteria used for the assessment of inorganic chemical accuracy are 75 to 125 percent for MS recoveries and 80 to 120 percent for LCS recoveries. For organic chemical accuracy, MS and LCS laboratory-specific percent recovery criteria developed and generated in-house by the laboratory according to approved laboratory procedures are applied. The criteria used for the assessment of radiochemical accuracy are 80 to 120 percent for LCS and MS recoveries.

Values outside the specified criteria do not necessarily result in the qualification of analytical data. It is only one factor in making an overall judgment about the quality of the reported analytical results. Factors beyond laboratory control, such as sample matrix effects, can cause the measured values to be outside of the established criteria. Therefore, the entire sampling and analytical process may be evaluated when determining the usability of the affected data.

The performance metric for assessing the DQI of accuracy on DQO decisions (Table 6-1) is that at least 80 percent of the sample results for each measured contaminant are not qualified for accuracy. If 
this performance is not met, an assessment will be conducted in the investigation report on the impacts to DQO decisions specific to affected contaminants and CASs.

\subsubsection{Representativeness}

Representativeness is the degree to which sample characteristics accurately and precisely represent the characteristics of a population or an environmental condition (EPA, 2002). Representativeness is assured by carefully developing the sampling strategy during the DQO process such that false negative and false positive decision errors are minimized. The criteria listed in DQO Step 6 - Specify the Tolerable Limits on Decision Errors are:

- For Decision I judgmental sampling, having a high degree of confidence that the sample locations selected will identify COCs if present anywhere within the CAS.

- Having a high degree of confidence that analyses conducted will be sufficient to detect any COCs present in the samples.

- For Decision II, having a high degree of confidence that the sample locations selected will identify the extent of COCs.

These are qualitative measures that will be used to assess measurement system performance for representativeness. The assessment of this qualitative criterion will be presented in the investigation report.

\subsubsection{Completeness}

Completeness is defined as generating sufficient data of the appropriate quality to satisfy the data needs identified in the DQOs. For judgmental sampling, completeness will be evaluated using both a quantitative measure and a qualitative assessment. The quantitative measurement to be used to evaluate completeness is presented in Table A.6-1 and is based on the percentage of measurements made that are judged to be valid.

For the judgmental sampling approach, the completeness goal for targeted contaminants and the remaining COPCs is 100 and 80 percent, respectively. If this goal is not achieved, the dataset will be assessed for potential impacts on making DQO decisions. 
The qualitative assessment of completeness is an evaluation of the sufficiency of information available to make DQO decisions. This assessment will be based on meeting the data needs identified in the DQOs and will be presented in the investigation report. If it is determined that the number of samples do not meet completeness criteria, additional samples will be collected.

\subsubsection{Comparability}

Comparability is a qualitative parameter expressing the confidence with which one dataset can be compared to another (EPA, 2002). The evaluation criteria for comparability will be that all sampling, handling, preparation, analysis, reporting, and data validation were performed using approved standard methods and procedures. This will ensure that data from this project can be compared to regulatory action levels that were developed based on data generated using the same or comparable methods and procedures. An evaluation of comparability will be presented in the investigation report.

\subsubsection{Sensitivity}

Sensitivity is the capability of a method or instrument to discriminate between measurement responses representing different levels of the variable of interest (EPA, 2002). The evaluation criteria for measurement sensitivity requires that detection limits will be less than or equal to the corresponding FALs. If this criterion is not achieved, the affected data will be assessed for usability and potential impacts on meeting site characterization objectives. This assessment will be presented in the investigation report. 


\subsection{Duration and Records Availability}

\subsection{Duration}

Table 7-1 is a tentative duration of activities (in calendar days) for corrective action investigation activities.

Table 7-1

Corrective Action Investigation Activity Durations

\begin{tabular}{|c|c|}
\hline Duration (days) & Activity \\
\hline \hline 10 & Site Preparation \\
\hline 76 & Field Work Preparation and Mobilization \\
\hline 20 & Sampling \\
\hline 160 & Data Assessment \\
\hline 180 & Waste Management \\
\hline
\end{tabular}

\subsection{Records Availability}

Historic information and documents referenced in this plan are retained in the NNSA/NSO project files in Las Vegas, Nevada, and can be obtained through written request to the NNSA/NSO Environmental Restoration Federal Project Director. This document is available in the DOE public reading rooms located in Las Vegas and Carson City, Nevada, or by contacting the appropriate DOE project manager. The NDEP maintains the official Administrative Record for all activities conducted under the auspices of the FFACO. 


\subsection{References}

ARL/SORD, see Air Resources Laboratory/Special Operations and Research Division.

ASTM, see American Society for Testing and Materials.

Air Resources Laboratory/Special Operations and Research Division. 2006. NTS Climatological Rain Gauge Data website. As accessed at http://www.sord.nv.goe/home_climate_rain.htm on 20 November.

American Society for Testing and Materials. 1995. Standard Guide for Risk-Based Corrective Action Applied at Petroleum Release Sites, ASTM E 1739-95 (Reapproved 2002). Philadelphia, PA.

American Society for Testing and Materials. 2000. Standard Test Method for Radiochemical Determination of Uranium in Soil by Alpha Spectroscopy, ASTM C 1000-00.

West Conshohocken, PA: ASTM International.

American Society for Testing and Materials. 2002. Standard Test Method for Radiochemical Determination of Plutonium in Soil by Alpha Spectroscopy, ASTM C 1001-02.

West Conshohocken, PA: ASTM International.

BN, see Bechtel Nevada.

Bechtel Nevada. 1995. Nevada Test Site Performance Objective for Certification of Nonradioactive Hazardous Waste, Rev. 0, G-E11/96.01. Las Vegas, NV.

CFR, see Code of Federal Regulations.

Code of Federal Regulations. 2003a. Title 40 CFR, Parts 761, "Polychlorinated Biphenyls (PCBs) Manufacturing, Processing, Distribution in Commerce, and Use Prohibitions.” Washington, DC: U.S. Government Printing Office.

Code of Federal Regulations. 2003b. Title 40 CFR, Part 763, “Asbestos.” Washington, DC:

U.S. Government Printing Office.

Code of Federal Regulations. 2006. Title 40 CFR, Parts 260-282, "Hazardous Waste Management System: General.” Washington, DC: U.S. Government Printing Office.

DOE, see U.S. Department of Energy.

DOE/NV, see U.S. Department of Energy, Nevada Operations Office.

DRI, see Desert Research Institute. 
Desert Research Institute. 1988. CERCLA Preliminary Assessment of DOE's Nevada Operations Office, Nuclear Weapons Testing Areas, April. Las Vegas, NV.

Desert Research Institute. 1993. Tritium Activities in Selected Wells on the Nevada Test Site, May, DOE/NV/10162-14. Prepared by R.F. Lyles. Las Vegas, NV: Water Resources Center.

EPA, see U.S. Environmental Protection Agency.

ERDA, see U.S. Energy Research and Development Administration.

EG\&G Rocky Flats. 1991. General Radiochemistry and Routine Analytical Services Protocol (GRASP), Version 2.1, July. Golden, CO: Environmental Management Department.

FFACO, see Federal Facility Agreement and Consent Order.

Fahringer, P., Stoller-Navarro Joint Venture. 2005. Memorandum to C. Sloop (SNJV) entitled, "CAU 556, CASs 25-64-01, 06-20-04, and 25-60-03 Geophysics - Memorandum of Findings," 19 October. Las Vegas, NV.

Federal Facility Agreement and Consent Order. 1996 (as amended). Agreed to by the State of Nevada, the U.S. Department of Energy, and the U.S. Department of Defense.

Moore, J., Science Applications International Corporation. 1999. Memorandum to M. Todd (SAIC) entitled, "Background Concentrations for NTS and TTR Soil Samples," 3 February. Las Vegas, NV: IT Corporation.

Murphy, T., Bureau of Federal Facilities. 2004. Letter to R. Bangerter (NNSA/NSO) entitled, "Review of Industrial Sites Project Document Guidance for Calculating Industrial Sites Project Remediation Goals for Radionuclides in Soil Using the Residual Radiation (RESRAD) Computer Code.” 19 November. Las Vegas, NV.

NAC, see Nevada Administrative Code.

NBMG, see Nevada Bureau of Mines and Geology.

NCRP, see National Council on Radiation Protection and Measurements.

NDEP, see Nevada Division of Environmental Protection.

NNSA/NSO, see U.S. Department of Energy, National Nuclear Security Administration Nevada Site Office.

NNSA/NV, see U.S. Department of Energy, National Nuclear Security Administration Nevada Operations Office. 
NOAA, see National Oceanic and Atmospheric Administration.

NRS, see Nevada Revised Statutes.

National Council on Radiation Protection and Measurements. 1999. Recommended Screening Limits for Contaminated Surface Soil and Review of Factors Relevant to Site-Specific Studies, NCRP Report No. 129. Bethesda, MD.

National Oceanic and Atmospheric Administration. 2002. "Precipitation Summary." As accessed at http://www.sord.nv.doe.gov/home_climate.htm on 27 November 2006.

Nevada Administrative Code. 2006a. NAC 444, "Sanitation.” Carson City, NV. As accessed at http://www.leg.state.nv.us/nac on 27 November.

Nevada Administrative Code. 2006b. NAC 445A.227, “Contamination of Soil: Order by Director for Corrective Action; Factors To Be Considered in Determining Whether Corrective Action Required.” Carson City, NV. As accessed at http://www.leg.state.nv.us/nac on 27 November.

Nevada Administrative Code. 2006c. NAC 445A.22705, “Contamination of Soil: Evaluation of Site by Owner or Operator; Review of Evaluation by Division.” Carson City, NV. As accessed at http://www.leg.state.nv.us/nac on 27 November.

Nevada Administrative Code. 2006d. NAC 445A.2272, "Contamination of Soil: Establishment of Action Levels.” Carson City, NV. As accessed at http://www.leg.state.nv.us/nac on 27 November.

Nevada Bureau of Mines and Geology. 1998. Mineral and Energy Resource Assessment of the Nellis Air Force Range, Open-File Report 98-1. Reno, NV.

Nevada Division of Environmental Protection. 1995. Mutual Consent Agreement between the State of Nevada and the U.S. Department of Energy for the Storage of Low-Level Land Disposal Restricted Mixed Waste. Carson City, NV.

Nevada Division of Environmental Protection. 1997a. Class II Solid Waste Disposal Site for Municipal and Solid Waste, Area 23 of the NTS, Permit SW 13-097-04. Carson City, NV.

Nevada Division of Environmental Protection. 1997b (as amended in August 2000). Class III Solid Waste Disposal Site for Hydrocarbon Burdened Soils, Area 6 of the NTS, Permit SW 13-097-02. Carson City, NV.

Nevada Division of Environmental Protection. 1997c (as amended in August 2000). Class III Solid Waste Disposal Site; UIOC, Area 9 of the NTS, Permit SW 13-097-03. Carson City, NV.

Nevada Division of Environmental Protection. 2005. Nevada Test Site Permit for Hazardous Waste Management Facility (NEV HW0021). Las Vegas, NV. 
Nevada Revised Statutes. 2005a. NRS 444.440 - 444.620, “Collection and Disposal of Solid Waste.” Carson City, NV.

Nevada Revised Statutes. 2005b. NRS 459.400 - 459.600, “Disposal of Hazardous Waste.” Carson City, NV.

Nevada Revised Statutes. 2005c. NRS 618.750 - 618.840, “Disposal of Hazardous Waste.” Carson City, NV.

Paar, J.G., and D.R. Porterfield. 1997. Evaluation of Radiochemical Data Usability, April, ES/ER/MS-5. Oak Ridge, TN: U.S. Department of Energy.

SNJV GIS Systems, see Stoller-Navarro Joint Venture Geographic Information Systems.

Shott, G.J., V. Yucel, M.J. Sully, L.E. Barker, S.E. Rawlinson, and B.A. Moore. 1997. Performance Assessment/Composite Analysis for the Area 3 Radioactive Waste Management Site at the Nevada Test Site, Nye County, Nevada, Rev. 2.0. Las Vegas, NV.

Stoller-Navarro Joint Venture Geographic Information Systems. 2007. ESRI ArcGIS Software.

USC, see United State Code.

USGS, see U.S. Geological Survey.

USGS and AEC, see U.S. Geological Survey and U.S. Atomic Energy Commission.

USGS and DOE, see U.S. Geological Survey and U.S. Department of Energy.

United States Code. 1976. 15 USC 2601 et seq., “Toxic Substances Control Act.” Enacted by Public Law No. 94-469, as amended. Washington, DC: U.S. Government Printing Office.

U.S. Department of Energy. 1988. Environmental Survey Preliminary Report, Nevada Test Site, Mercury, Nevada. Washington, DC: Environment, Safety, and Health Office of Environmental Audit.

U.S. Department of Energy. 1993. Radiation Protection of the Public and the Environment, DOE Order 5400.5, Change 2. Washington, DC: U.S. Government Printing Office.

U.S. Department of Energy. 1997. The Procedures Manual of the Environmental Measurements Laboratory, HASL-300, 28th Ed., Vol. I. New York, NY.

U.S. Department of Energy, Nevada Operations Office. 1992. Remedial Investigation and Feasibility Study for the Plutonium Contaminated Soils at Nevada Test Site, Nellis Air Force Range and Tonopah Test Range, April. Las Vegas, NV. 
U.S. Department of Energy, Nevada Operations Office. 1996. Final Environmental Impact Statement for the Nevada Test Site and Off-Site Locations in the State of Nevada, DOE/EIS 0243. Las Vegas, NV.

U.S. Department of Energy, Nevada Operations Office. 1997. Integrated Safety Management Policy, DOE Order NV P 450.4. Las Vegas, NV.

U.S. Department of Energy, Nevada Operations Office. 1998. Nevada Test Site Resource Management Plan. DOE/NV--518, Las Vegas, NV.

U.S. Department of Energy, National Nuclear Security Administration Nevada Operations Office. 2002a. Industrial Sites Quality Assurance Project Plan, Nevada Test Site, Nevada, Rev. 3, DOE/NV--372. Las Vegas, NV.

U.S. Department of Energy, National Nuclear Security Administration Nevada Operations Office. 2002b. Underground Test Area Project Waste Management Plan, DOE/NV--343-Rev. 2. Las Vegas, NV.

U.S. Department of Energy, National Nuclear Security Administration Nevada Site Office. 2004. NV/YMP Radiological Control Manual, Rev. 5, DOE/NV/11718--079, UC-702. Prepared by Bechtel Nevada. Las Vegas, NV.

U.S. Department of Energy, National Nuclear Security Administration Nevada Site Office. 2005. Nevada Test Site Waste Acceptance Criteria, DOE/NV--325, Rev. 6. Las Vegas, NV.

U.S. Department of Energy, National Nuclear Security Administration Nevada Site Office. 2006. Industrial Sites Project Establishment of Final Action Levels, DOE/NV--1107, Rev. 0. Las Vegas, NV.

U.S. Energy Research and Development Administration. 1977. Final Environmental Impact Statement, Nevada Test Site, Nye County, Nevada, ERDA-1551, Washington, DC.

U.S. Environmental Protection Agency. 1988. Contract Laboratory Program Statement of Work for Inorganic Analysis, SOW No. 788, EPA/540/R-94/093. Washington, DC.

U.S. Environmental Protection Agency. 1994. Contract Laboratory Program Statement of Work for Inorganic Analysis, ILMO 3.0, EPA/540/R-94/076. Washington, DC.

U.S. Environmental Protection Agency. 1995. Contract Laboratory Program Statement of Work for Inorganic Analysis, ILMO 4.0, EPA/540/R-95/121. Washington, DC.

U.S. Environmental Protection Agency. 1996. Test Method for Evaluating Solid Waste Physical/Chemical Methods, SW-846, 3rd Edition. Washington, DC. 
U.S. Environmental Protection Agency. 2002. Guidance for Quality Assurance Project Plans, EPA QA/G5. Washington, DC.

U.S. Environmental Protection Agency. 2003. Contract Laboratory Program Statement of Work for Organic Data Review, Multi-media Multi-concentration Document Number OLMO4.3, January 2000.

U.S. Environmental Protection Agency. 2004. Region 9 Preliminary Remediation Goals (PRGs). As accessed at http://www.epa.gov/region09/waste/sfund/prg/index.htm on 27 November 2006. Prepared by S.J. Smucker. San Francisco, CA.

U.S. Geological Survey. 1990. Geologic Map of the Nevada Test Site, Southern Nevada, USGS Map I-2046. Denver, CO.

U.S. Geological Survey. 1996. Summary of Hydrogeological Controls on Groundwater Flow at the Nevada Test Site, Nye County, Nevada, USGS WRIR 96-4109. Prepared by R.J. Laczniak, J.C. Cole, D.A. Sawyer, and D.A. Trudeau.

U.S. Geological Survey and U.S. Atomic Energy Commission. 1964. Geology of the Jackass Flats Quadrangle, Nye County, Nevada. Prepared by E.J. McKay and W.P. Williams. Las Vegas, NV.

U.S. Geological Survey and U.S. Department of Energy. 2005. "USGS/DOE Nevada WW-2 Site Page.” As accessed at http://nevada.usgs.gov/doe_nv on 20 November 2006.

Winograd, I.J., and W. Thordarson. 1975. Hydrology and Hydrochemical Framework, South-Central Great Basin, Nevada-California, with Special Reference to the Nevada Test Site, USGS Professional Paper 712-C. Denver, CO. 


\section{Appendix A}

\section{Data Quality Objectives}




\section{A.1.0 Introduction}

The DQO process described in this appendix is a seven-step strategic systematic planning method used to plan data collection activities and define performance criteria for the CAU 556, Dry Wells and Surface Release Points, field investigation. The DQOs are designed to ensure that the data collected will provide sufficient and reliable information to identify, evaluate, and technically defend recommended corrective actions (i.e., no further action, closure in place, or clean closure). Existing information about the nature and extent of contamination at the CASs in CAU 556 is insufficient to evaluate and select preferred corrective actions; therefore, a CAI will be conducted.

The CAU 556 investigation will be based on the DQOs presented in this appendix as developed by representatives of the NDEP and the NNSA/NSO. The seven steps of the DQO process presented in Sections A.3.0 through A.9.0 were developed in accordance with EPA Guidance on Systematic Planning using the Data Quality Objectives Process (EPA, 2006).

The DQO process presents a judgmental sampling approach. In general, the procedures used in the DQO process provide:

- A method to establish performance or acceptance criteria, which serve as the basis for designing a plan for collecting data of sufficient quality and quantity to support the goals of a study.

- Criteria used to establish the final data collection design are:

- The nature of the problem to initiate the study and a conceptual model of the environmental hazard to be investigated.

- The decisions or estimates necessary to be made and prioritizing them for resolution.

- The data type needed.

- An analytic approach or decision rule to define the logic for how data will be used to draw conclusions from the study findings.

- Acceptable quantitative criteria on the quality and quantity of data to be collected, relative to the ultimate use of the data.

- A data collection design that generates data that meets the quantitative and qualitative criteria specified. A data collection design specifies the type, number, location, and physical quantity 
of samples and data, as well as the QA/QC activities that ensure sampling design and measurement errors are managed sufficiently, to meet the performance or acceptance criteria specified in the DQOs. 


\section{A.2.0 Background Information}

The following four CASs that comprise CAU 556 are located in Areas 6 and 25 of the NTS, as shown in Figure A.2-1:

- 06-20-04, National Cementers Dry Well

- 06-99-09, Birdwell Test Hole

- 25-60-03, E-MAD Stormwater Discharge and Piping

- 25-64-01, Vehicle Washdown and Drainage Pit

The following sections (Sections A.2.1 through A.2.4) provide a CAS description, physical setting and operational history, release information, and previous investigation results for each CAS in CAU 556. The CAS-specific COPCs are provided in the following sections. Many of the COPCs are based on a conservative evaluation of possible site activities considering the incomplete site histories of the CASs and considering contaminants found at similar NTS sites. Targeted contaminants are defined as those contaminants that are known or that could be reasonably suspected to be present within the CAS based on previous sampling or process knowledge.

\section{A.2.1 Corrective Action Site 06-20-04, National Cementers Dry Well}

Corrective Action Site 06-20-04 is the National Cementers Dry Well, associated piping from the well up to the cement pad that once was the foundation for the metals shop, and the impacted soil surrounding these features. The shallow dry well is located approximately $10 \mathrm{ft}$ to the west of the cement pad that received effluent from the drain line in the floor of the metals shop cement pad. An engineering drawing indicates that the National Cementers Dry Well consisted of an approximately 4-ft diameter hole approximately $5 \mathrm{ft}$ deep containing a perforated PVC pipe oriented horizontally in the well on a 2.5- to 3-ft deep bed of washed aggregate. The PVC pipe and underlying washed aggregate was covered again with $1.5 \mathrm{ft}$ of untreated building paper and then covered again with native material to ground level. The PVC pipe is connected to the 3-in. diameter, 10-ft long cast iron pipe from which effluent from the metals shop was introduced into the well. The effluent from the metals shop floor drain ran through the cast iron pipe then percolated through the perforated PVC pipe into the washed aggregate. Figure A.2-2 shows a site sketch of the CAS. 


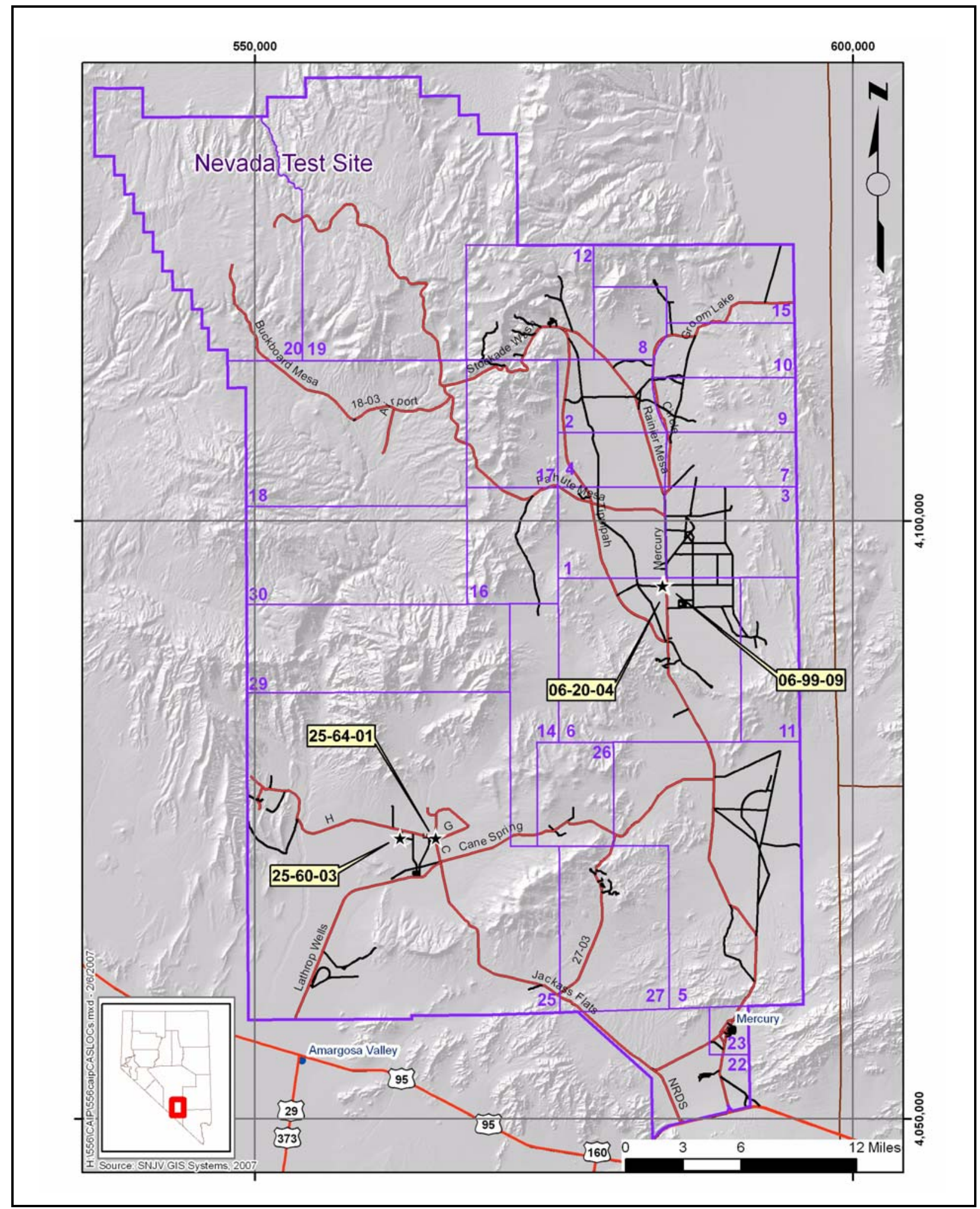

Figure A.2-1

Corrective Action Unit 556, CAS Location Map 


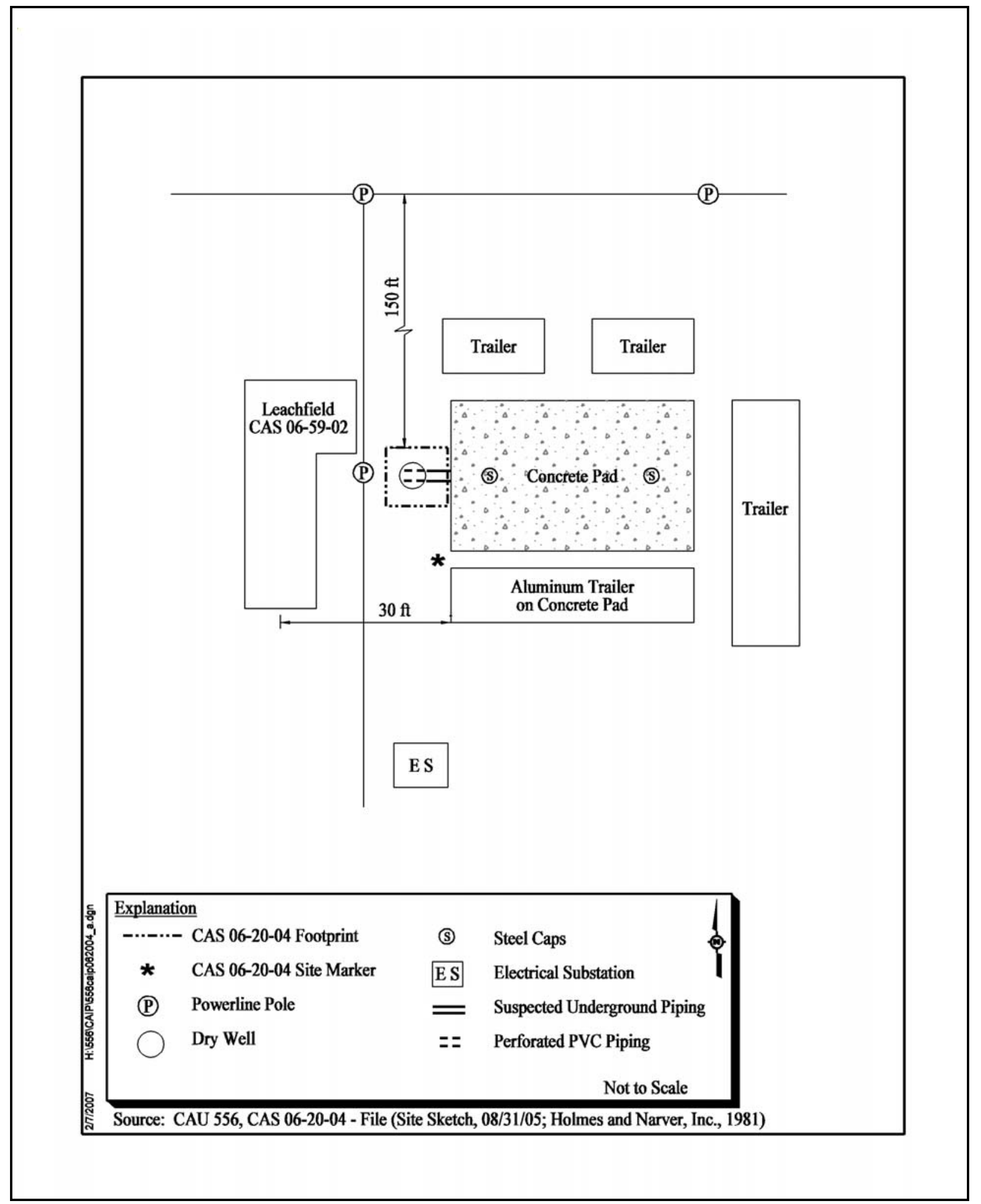

Figure A.2-2

Site Sketch of CAS 06-20-04, National Cementers Dry Well 
Physical Setting and Operational History - CAS 06-20-04 is located in the Well 3 Yard in Area 6 of the NTS. The National Cementers Facilities, including the metals shop, were operated from approximately 1963 through the early 1990s. The contract for cementing operations at the National Cementers Facility was owned by Halliburton from 1963 through 1983, and then by B.J. Titan from 1983 through the early 1990s, when operations stopped. The dry well was first identified following a review of engineering drawings. The engineering drawing entitled Birdwell \& National Cement Facilities Water and Sewer System Plot Plan, Section \& Detail shows the National Cementers Dry Well located west of the metals shop. The metals shop was believed to have been demolished shortly after operations ceased at the National Cementers Facilities in the early 1990s.

Release Information - The two floor drains in the former National Cementers metals shop are connected via underground piping to the National Cementers Dry Well. Metals shop operations reportedly included a dip tank that typically contained solvents such as 1,1,1-trichloroethane and Stoddard Solvent. There is no indication that any of the degreasing solvents were placed into the floor drains. Along with the 1,1,1-trichloroethane and Stoddard Solvent an interviewee indicated that soap and water solutions may also have been used and placed into the floor drains and consequently the dry well.

Previous Investigation Results - On October 19, 2005, a geophysical survey was conducted over an area including the National Cementers Dry Well. The survey did not show any anomalous readings in the area of the dry well, as would be expected considering the dry well is an earthen (non-metallic) entity with no associated metal components. The geophysical survey also did not find the 3-in. diameter cast iron line that is shown in engineering drawings to run from the floor drains at the former metals shop to the dry well. No radiological survey has been conducted at CAS 06-20-04. No samples have been collected for chemical or radionuclide analysis from CAS 06-20-04.

\section{A.2.2 Corrective Action Site 06-99-09, Birdwell Test Hole}

Corrective Action Site 06-99-09 consists of the Birdwell Test Hole that is approximately $47 \mathrm{ft}$ deep and two smaller diameter test holes just to the east and west of the Birdwell Test Hole that are of unknown depth. All three test holes are believed to be sealed at the bottom and cased to contain the water used for waterproofing and instrument signal tests conducted at the site. Figure A.2-3 shows a site sketch of CAS 06-99-09. 


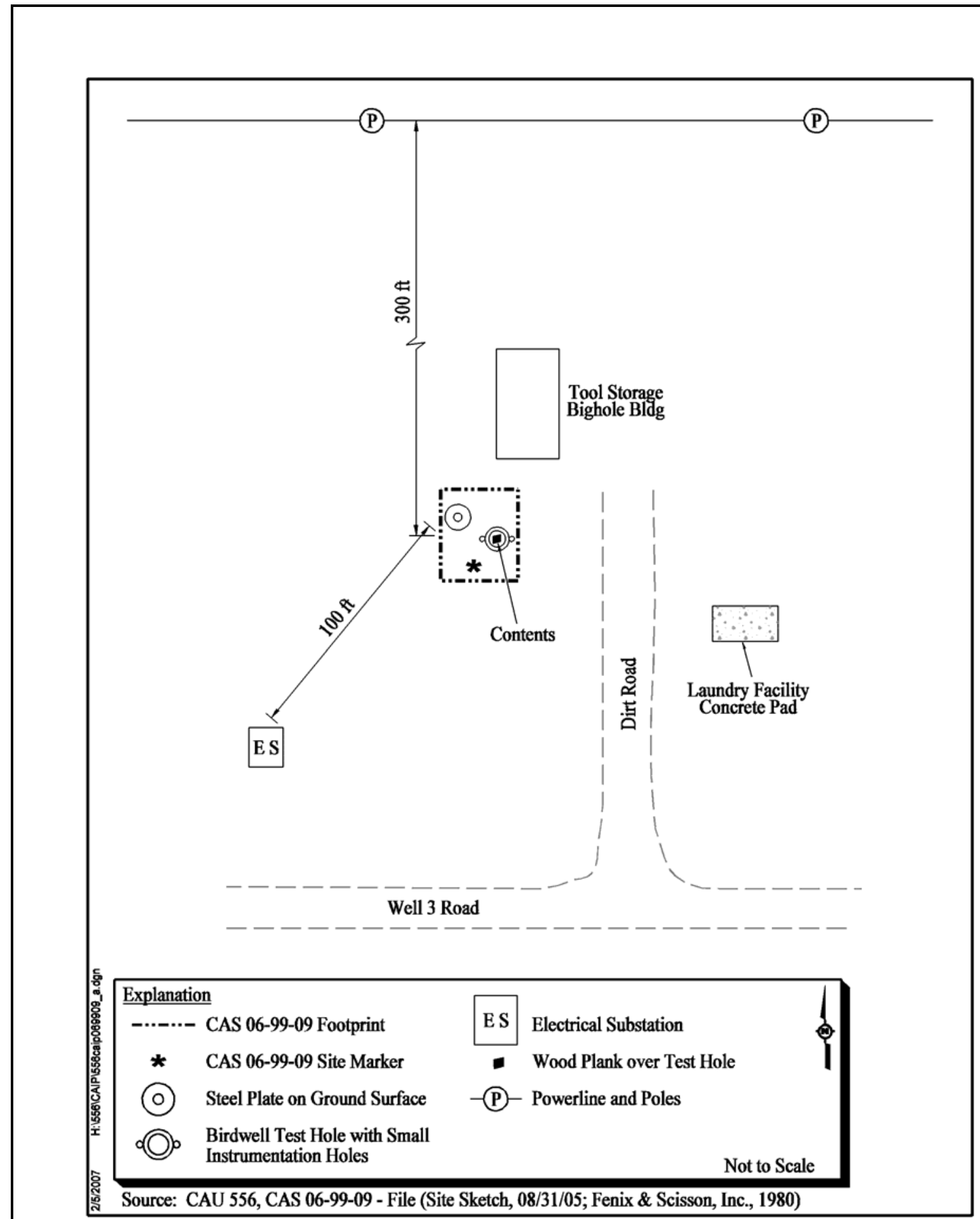

Figure A.2-3

Site Sketch of CAS 06-99-09, Birdwell Test Hole 
Physical Setting and Operational History - The CAS is located in the Well 3 Yard of Area 6 of the NTS. The test holes are just south of the Tool Storage Bighole Building at the Birdwell Complex. The Birdwell and Atlas Wireline logging companies performed downhole logging operations at the NTS. Birdwell operated from approximately 1963 to 1985, at which time Atlas Wireline bought and operated the site until the early 1990s. The Birdwell Test Hole was drilled on September 22, 1976, to a depth of $47 \mathrm{ft}$. An approximately 5-ft seal is believed to have been placed at the bottom of the well. It is unknown if the two instrument holes are similarly sealed at the bottom, but it is likely because they were also designed to be watertight for instrument signal testing. The Birdwell Test Hole and the two smaller holes were used from 1976 until approximately 1992, when underground testing ceased at the NTS. All three test holes were cased so that they could be filled with water. The Birdwell hole was used for waterproof testing of downhole instrumentation, and the two smaller holes were used for instrument signal tests in a downhole simulation test. The two smaller holes were sometimes filled with water and a small amount of dishwashing liquid to improve instrument signal transmissivity when underwater operation of the instruments was conducted. Occasionally, the water in the holes were pumped out when not in use.

Release Information - Information indicates that the three test holes were designed to be watertight and therefore plugged and cased. Currently, water resides within the Birdwell Test Hole, providing verification of its integrity as a watertight system. Therefore, it is assumed that there has been no release to the environment.

Previous Investigation Results - There have been no geophysical, radiological, or analytical investigations of CAS 06-99-09.

\section{A.2.3 Corrective Action Site 25-60-03, E-MAD Stormwater Discharge and Piping}

Corrective Action Site 25-60-03 consists of an 18-in. diameter corrugated pipe system that is used to collect stormwater runoff and route it to the desert southwest of the E-MAD Facility in Area 25 of the NTS and includes three subsurface catch basins and a manhole. The catch basins and corrugated piping are approximately $10 \mathrm{ft}$ bgs. The entire length of the stormwater drain system runs approximately $750 \mathrm{ft}$ from the easternmost catch basin to the corrugated piping outfall, turning toward the southwest at the westernmost set of railroad tracks within the E-MAD Facility. Figure A.2-4 is a site sketch of CAS 25-60-03. 


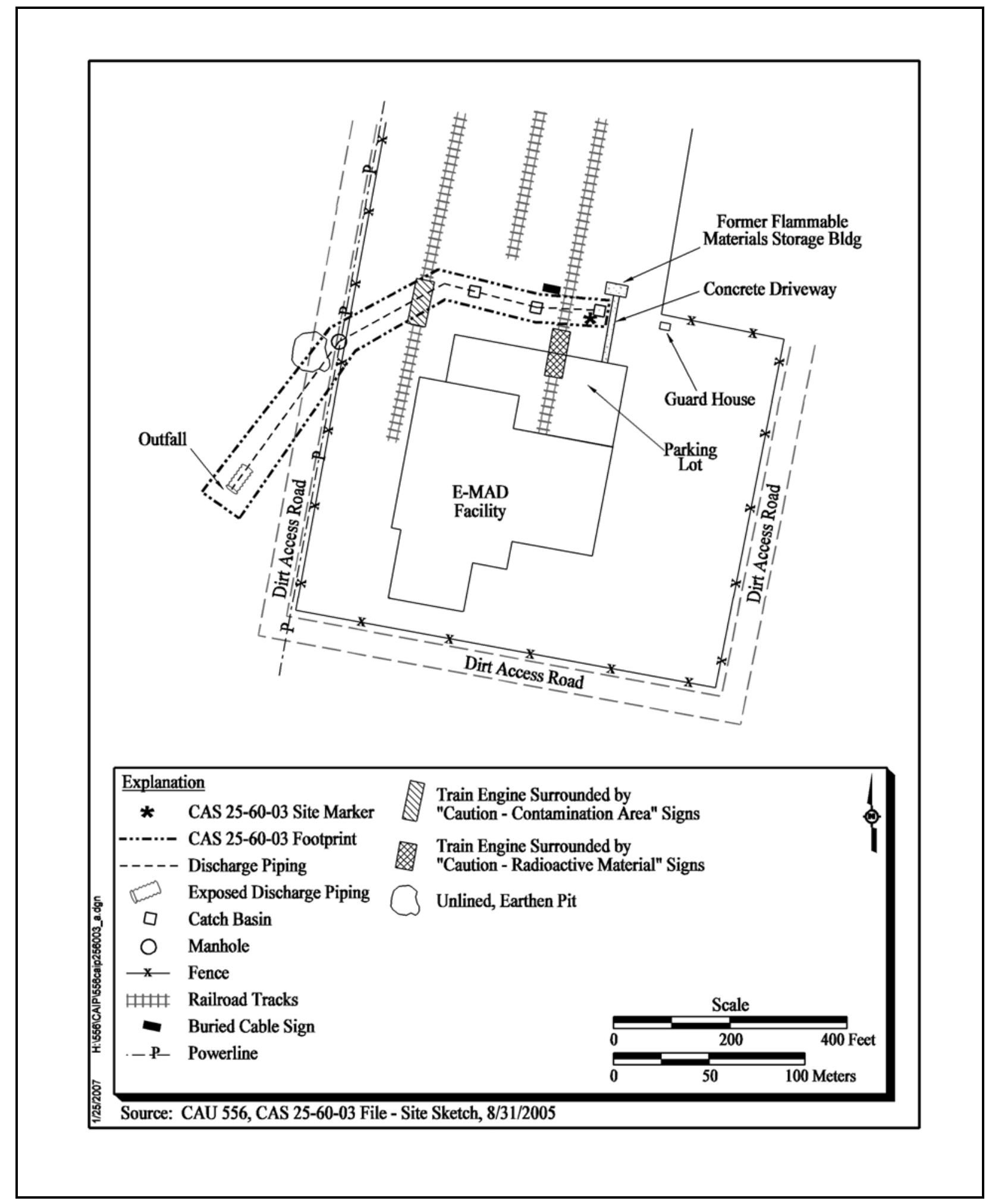

Figure A.2-4

Site Sketch of CAS 25-60-03, E-MAD Stormwater Discharge and Piping 
Physical Setting and Operational History - Corrective Action Site 25-60-03, an unmaintained and active stormwater discharge system, is located on the northern side of the E-MAD Facility, while the discharge piping is located outside the southwest section of the facility. The stormwater discharge system is shown on a Vitro Engineering Co. drawing in 1965. The system is still in use as a stormwater drainage system, but because of the current physical layout of the area around the stormwater system, it only is an effective water removal system when heavy precipitation occurs.

Release Information - Corrective Action Site 25-25-04, Oil Spills (CAU 398), contained soils immediately adjacent to the easternmost catch basin that were removed in 2003 because of the presence of contamination. The contaminants found at CAS 25-25-04 were TPH, PCBs, and RCRA metals. Due to the location of these sources as soil contaminants, it is possible that similar contaminants were released to CAS 25-60-03. Direct releases in the form of discarded solvents and other materials to the soils directly adjacent to the easternmost catch basin likely entered the stormwater discharge system during stormwater events and were promoted through the system during subsequent stormwater events.

Currently, release is possible from any discontinuity along the system piping, cracks or other openings within any of the catch basins and manway box beneath the manhole, and at the outfall of the system piping. Any releases may contain the contaminants identified in the investigation of CAS 25-25-04.

Previous Investigation Results - No samples have been collected from this CAS. The soil removed from around the easternmost catch basin as part of CAS 25-25-04 is an indicator of the possibility of contamination within the stormwater drainage system. In November 2005, a geophysical survey was conducted that identified a continuous running pipe from the outfall to a manhole just outside the western fence of the E-MAD Facility (approximately $312 \mathrm{ft}$ ). No radiological survey has been conducted for CAS 25-60-03.

\section{A.2.4 Corrective Action Site 25-64-01, Vehicle Washdown and Drainage Pit}

Corrective Action Site 25-64-01 consists of a vehicle washdown pad and a drainage pit at the northeast corner of the intersection of F and G Roads in Area 25 of the NTS near the RCP. The soils beneath both are also a part of the CAS. The vehicle washdown pad is located adjacent to the 
northwest corner of the drainage pit. A 2-in. diameter pipe is visible at the southeast end of the washdown pad, and extends through a berm to the drainage pit. The drainage pit is approximately 300 by 70 by $7 \mathrm{ft}$ deep. A naturally formed wash is also present between the vehicle washdown pad and the drainage pit. Due to common practices, it should be assumed that drain water input to the drainage pit will be localized to the area where the pipe and natural wash enter the pit. Debris is scattered throughout the drainage pit. Figure A.2-5 shows a site sketch of CAS 25-64-01.

Physical Setting and Operational History - The vehicle washdown pad and drainage pit are located just north of CAS 25-07-07, Vehicle Washdown Area (CAU 165), and is believed to have served the same purpose as CAS 25-07-07. Vehicles leaving Test Cell C (TCC) and Test Cell A (TCA) were checked for radionuclide contamination before returning to the RCP Facility. Contaminated vehicles were placed on one of the two vehicle washdown pads and decontaminated, with the effluent moving from the washdown pad to the drainage pit. It is believed that the washdown pads operated from approximately 1958 to 1973, when the Nuclear Rocket Development Station Project ended.

Release Information - Contaminants potentially released to the CAS during operations include TPH and radionuclides, as well as cleaning solution components used at the vehicle washdown pad. These components include phosphates from detergents (not a contaminant) and potentially Freon-10 (carbon tetrachloride).

Previous Investigation Results - No samples have been collected for analysis from CAS 25-64-01. In November 2005, a geophysical survey was conducted that identified the pipe protruding from the vehicle washdown area is connected to the pipe that protrudes into the drainage pit. The geophysical survey also confirmed there is no underground connection between the CAS 25-64-01 drainage pit and the CAS 25-07-07 sump located just to the south of the drainage pit. A radiological survey of CAS 25-64-01 was conducted on September 21, 2006, and found no readings above 1.4 times background levels. The higher readings were associated with the vehicle washdown pad and the area in the drainage pit that would have received effluent from the washdown pad.

Corrective Action Site 25-07-07, located just off the southern end of the CAS 25-64-01 drainage pit, was found to contain TPH as the only COC when it was investigated as part of CAU 165 in 2004. 


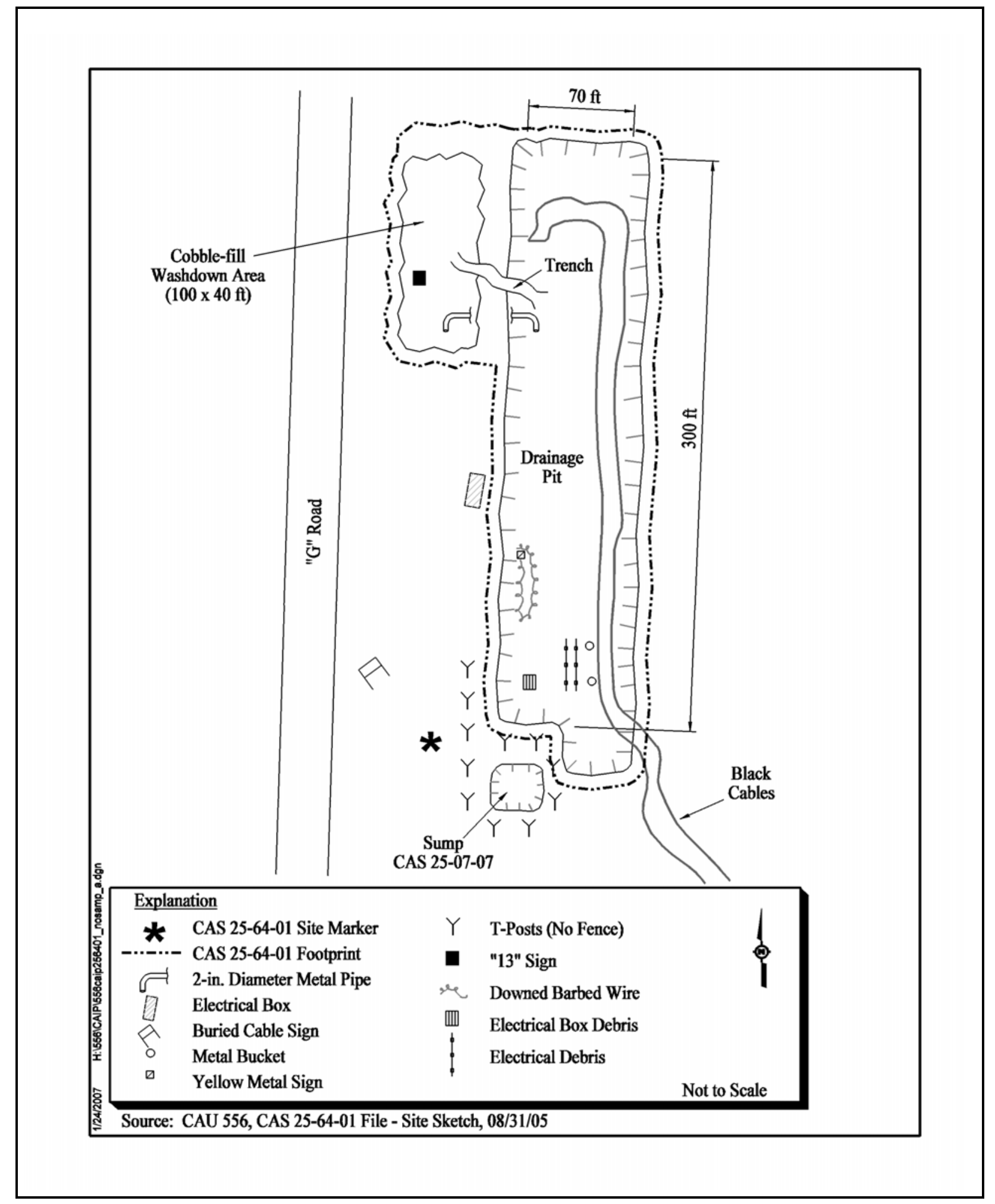

Figure A.2-5

Site Sketch of CAS 25-64-01, Vehicle Washdown and Drainage Pit 


\section{A.3.0 Step 1 - State the Problem}

Step 1 of the DQO process defines the problem that requires study; identifies the planning team, and develops a conceptual model of the environmental hazard to be investigated.

The problem statement for CAU 556 is: "Existing information on the nature and extent of potential contamination is insufficient to evaluate and recommend corrective action alternatives for the CASs in CAU 556.”

\section{A.3.1 Planning Team Members}

The DQO planning team consists of representatives from NDEP, NNSA/NSO, SNJV, and NSTec. The DQO planning team met on November 14, 2006, for the DQO meeting. The primary decision-makers are the NDEP and NNSA/NSO representatives. The functional areas represented at the DQO planning meeting are listed in Table A.3-1.

Table A.3-1

DQO Meeting Participants for CAU 556 November 14, 2006

\begin{tabular}{||c|c|}
\hline Function & Affiliation \\
\hline \hline Regulatory Representative and Oversight & Nevada Division of Environmental Protection \\
\hline $\begin{array}{c}\text { National Nuclear Security Administration } \\
\text { Nevada Site Office } \\
\text { Task Manager }\end{array}$ & $\begin{array}{c}\text { U.S. Department of Energy, } \\
\text { National Nuclear Security Administration } \\
\text { Nevada Site Office }\end{array}$ \\
\hline Industrial Sites Project Manager & Stoller-Navarro Joint Venture \\
\hline Industrial Sites Task Manager & Stoller-Navarro Joint Venture \\
\hline Industrial Sites CAU Lead & Stoller-Navarro Joint Venture \\
\hline Waste Management Representative & Stoller-Navarro Joint Venture \\
\hline Quality Processes Representative & Stoller-Navarro Joint Venture \\
\hline Environmental Restoration Task Lead & National Securities Technologies, LLC \\
\hline
\end{tabular}

\section{A.3.2 Conceptual Site Model}

The CSM is used to organize and communicate information about site characteristics. It reflects the best interpretation of available information at any point in time. The CSM is a primary vehicle for communicating assumptions about release mechanisms, potential migration pathways, or specific constraints. It provides a good summary of how and where contaminants are expected to move and 
the impacts of such movement. It is the basis to assess how contaminants could reach receptors in the present and future. The CSM describes the most probable scenario for current conditions at each site and define the assumptions that are the basis for identifying appropriate sampling strategy and data collection methods. Accurate CSMs are important as they serve as the basis for all subsequent inputs and decisions throughout the DQO process.

The CSMs were developed for CAU 556 using information from the physical setting, potential contaminant sources, release information, historical background information, knowledge from similar sites, and physical and chemical properties of the potentially affected media and COPCs.

The CSM consists of:

- Potential contaminant releases including media subsequently affected.

- Release mechanisms (the conditions associated with the release).

- Potential contaminant source characteristics including contaminants suspected to be present and contaminant-specific properties.

- Site characteristics including physical, topographical, and meteorological information.

- Migration pathways and transport mechanisms that describe the potential for migration and where the contamination may be transported.

- The locations of points of exposure where individuals or populations may come in contact with a COC associated with a CAS.

- Routes of exposure where contaminants may enter the receptor.

If additional elements are identified during the investigation that are outside the scope of the CSM, the situation will be reviewed and a recommendation will be made as to how to proceed. In such cases, NDEP and NNSA/NSO will be notified of the recommendation and offered the opportunity to comment or concur. 
The applicability of the CSM to each CAS is summarized in Table A.3-2 which provides information on CSM elements that will be used throughout the remaining steps of the DQO process and are discussed below. Figure A.3-1 represents site conditions applicable to the CSM for CAS 06-20-04 and CAS 06-99-09. Figure A.3-2 represents site conditions applicable to the CSM for CAS 25-60-03, and Figure A.3-3 represents site conditions applicable to the CSM for CAS 25-64-01.

\section{A.3.2.1 Contaminant Release}

The most likely locations of the contamination and releases to the environment are the soils directly below or adjacent to the CSM surface and subsurface components (i.e., test wells, washdown pad, underground stormwater piping and outfall, drainage pit, and disposal wells). The CSM accounts for potential releases resulting from overflow of system components that are present at ground surface (e.g., washdown pad, drainage pit) and surface spills. Any contaminants migrating from CASs, regardless of physical or chemical characteristics, are expected to exist at interfaces and in the soil adjacent to disposal features in lateral and vertical directions. Additional contaminants may be released from the watershed of the stormwater system at CAS 25-60-03, which would enter the stormwater system during stormwater flow and be transported through the system to the outfall. 
Table A.3-2

Conceptual Site Model Description of Elements for Each CAS in CAU 556

(Page 1 of 4)

\begin{tabular}{|c|c|c|c|c|}
\hline CAS Identifier & $06-20-04$ & 06-99-09 & $25-60-03$ & 25-64-01 \\
\hline CAS Description & $\begin{array}{c}\text { National Cementers } \\
\text { Dry Well }\end{array}$ & Birdwell Test Hole & $\begin{array}{l}\text { E-MAD Stormwater } \\
\text { Discharge and Piping }\end{array}$ & $\begin{array}{c}\text { Vehicle Washdown and } \\
\text { Drainage Pit }\end{array}$ \\
\hline Site Status & \multicolumn{2}{|c|}{ Inactive and/or abandoned } & Active & Inactive and/or abandoned \\
\hline Exposure Scenario & \multicolumn{2}{|c|}{ Occasional Use Areas } & Remote Use Area & Occasional Use Area \\
\hline $\begin{array}{l}\text { Sources of Potential } \\
\text { Soil Contamination }\end{array}$ & $\begin{array}{l}\text { Infiltration into surrounding } \\
\text { soils from dry well }\end{array}$ & $\begin{array}{l}\text { It is assumed there is no soil } \\
\text { contamination }\end{array}$ & $\begin{array}{c}\text { Discarding/leaking of } \\
\text { contaminants into system }\end{array}$ & $\begin{array}{l}\text { Washdown effluent and } \\
\text { runoff into drainage pit }\end{array}$ \\
\hline $\begin{array}{l}\text { Location of } \\
\text { Contamination/ } \\
\text { Release Point }\end{array}$ & $\begin{array}{l}\text { Infiltration into soil from well } \\
\text { and from drain pipe }\end{array}$ & None anticipated & $\begin{array}{l}\text { Infiltration into soil from } \\
\text { breaks in piping and/or } \\
\text { catch basins and outfall } \\
\text { runoff }\end{array}$ & $\begin{array}{l}\text { Infiltration into subsurface } \\
\text { soil from vehicle washdown } \\
\text { pad and drainage pit }\end{array}$ \\
\hline Amount Released & Unknown & None anticipated & Unknown & Unknown \\
\hline Affected Media & Shallow subsurface soil & None anticipated & $\begin{array}{c}\text { Subsurface soils, and } \\
\text { surface and shallow } \\
\text { subsurface soils at outfall }\end{array}$ & $\begin{array}{l}\text { Surface and shallow } \\
\text { subsurface soils }\end{array}$ \\
\hline Potential Contaminants & $\begin{array}{c}\text { Chlorinated solvents, RCRA } \\
\text { metals }\end{array}$ & None anticipated & $\begin{array}{c}\text { TPH-DRO, RCRA metals, } \\
\text { PCBs }\end{array}$ & $\begin{array}{l}\text { TPH-DRO, carbon } \\
\text { tetrachloride }\end{array}$ \\
\hline
\end{tabular}


Table A.3-2

Conceptual Site Model Description of Elements for Each CAS in CAU 556

(Page 2 of 4 )

\begin{tabular}{|c|c|c|c|c|}
\hline CAS Identifier & $06-20-04$ & 06-99-09 & $25-60-03$ & $25-64-01$ \\
\hline CAS Description & $\begin{array}{c}\text { National Cementers } \\
\text { Dry Well }\end{array}$ & Birdwell Test Hole & $\begin{array}{l}\text { E-MAD Stormwater } \\
\text { Discharge and Piping }\end{array}$ & $\begin{array}{c}\text { Vehicle Washdown and } \\
\text { Drainage Pit }\end{array}$ \\
\hline Transport Mechanisms & $\begin{array}{l}\text { Percolation of precipitation } \\
\text { through subsurface media } \\
\text { serves as the major driving } \\
\text { force for migration of } \\
\text { contaminants. Surface } \\
\text { water runoff is negligible as } \\
\text { contaminants were } \\
\text { introduced underground. }\end{array}$ & None anticipated & $\begin{array}{l}\text { Stormwater events are the } \\
\text { major driving mechanism for } \\
\text { pushing contaminants } \\
\text { through the piping system to } \\
\text { the outfall, where } \\
\text { percolation and surface flow } \\
\text { from precipitation are the } \\
\text { driving mechanisms for the } \\
\text { transport of contaminants } \\
\text { within the footprint of the } \\
\text { CAS. Stormwater episodes } \\
\text { also have the potential to } \\
\text { add contaminants from } \\
\text { within the system watershed } \\
\text { to the collection, transport, } \\
\text { and outfall components of } \\
\text { the system. }\end{array}$ & $\begin{array}{l}\text { Percolation of precipitation } \\
\text { through subsurface media } \\
\text { serves as the major driving } \\
\text { force for migration of } \\
\text { contaminants. Surface } \\
\text { water runoff may provide for } \\
\text { the transportation of some } \\
\text { contaminants within the } \\
\text { footprints of the CASs. }\end{array}$ \\
\hline Migration Pathways & Vertical transport & None anticipated & $\begin{array}{l}\text { Lateral migration is } \\
\text { expected to dominate over } \\
\text { vertical migration as the } \\
\text { system is designed to move } \\
\text { runoff off site. }\end{array}$ & $\begin{array}{l}\text { Vertical transport expected } \\
\text { to dominate over lateral } \\
\text { transport due to small } \\
\text { surface gradients. }\end{array}$ \\
\hline
\end{tabular}


Table A.3-2

Conceptual Site Model Description of Elements for Each CAS in CAU 556

(Page 3 of 4 )

\begin{tabular}{|c|c|c|c|c|}
\hline CAS Identifier & $06-20-04$ & 06-99-09 & $25-60-03$ & 25-64-01 \\
\hline CAS Description & $\begin{array}{c}\text { National Cementers } \\
\text { Dry Well }\end{array}$ & Birdwell Test Hole & $\begin{array}{l}\text { E-MAD Stormwater } \\
\text { Discharge and Piping }\end{array}$ & $\begin{array}{c}\text { Vehicle Washdown and } \\
\text { Drainage Pit }\end{array}$ \\
\hline $\begin{array}{l}\text { Lateral and Vertical } \\
\text { Extent of } \\
\text { Contamination }\end{array}$ & $\begin{array}{l}\text { Contamination, if present, is } \\
\text { expected to be contiguous } \\
\text { to the release points. } \\
\text { Concentrations are } \\
\text { expected to decrease with } \\
\text { distance and depth from the } \\
\text { source. Groundwater } \\
\text { contamination is not } \\
\text { expected. Lateral and } \\
\text { vertical extent of COC } \\
\text { contamination is assumed to } \\
\text { be within the spatial } \\
\text { boundaries. }\end{array}$ & None anticipated & $\begin{array}{l}\text { Contamination, if present, is } \\
\text { expected to be contiguous } \\
\text { to the release points. } \\
\text { Concentrations are } \\
\text { expected to decrease with } \\
\text { distance and depth from the } \\
\text { source. Groundwater } \\
\text { contamination is not } \\
\text { expected. Vertical extent of } \\
\text { coc contamination is } \\
\text { assumed to be within the } \\
\text { spatial boundaries. Lateral } \\
\text { extent of COC } \\
\text { contamination may not be } \\
\text { within the spatial } \\
\text { boundaries. }\end{array}$ & $\begin{array}{l}\text { Contamination, if present, is } \\
\text { expected to be contiguous } \\
\text { to the release points. } \\
\text { Concentrations are } \\
\text { expected to decrease with } \\
\text { distance and depth from the } \\
\text { source. Groundwater } \\
\text { contamination is not } \\
\text { expected. Lateral and } \\
\text { vertical extent of COC } \\
\text { contamination is assumed to } \\
\text { be within the spatial } \\
\text { boundaries. }\end{array}$ \\
\hline Exposure Pathways & $\begin{array}{l}\text { None, because they are } \\
\text { subsurface, beyond } \\
\text { excavation depth, and do } \\
\text { not reach groundwater. }\end{array}$ & $\begin{array}{l}\text { There is no potential for } \\
\text { exposure to contaminants } \\
\text { as it is anticipated that no } \\
\text { contaminants exist at this } \\
\text { CAS. The nature and use of } \\
\text { this CAS indicated that the } \\
\text { wells are watertight and the } \\
\text { contents are by process } \\
\text { supposed to be water. }\end{array}$ & \multicolumn{2}{|c|}{$\begin{array}{l}\text { The potential for contamination exposure is limited to } \\
\text { industrial and construction workers, and military personnel } \\
\text { contacting contaminated surface materials. These human } \\
\text { receptors may be exposed to COPCs through oral ingestion, } \\
\text { inhalation, dermal contact (absorption) of surface soil and/or } \\
\text { debris due to inadvertent disturbance of these materials or } \\
\text { irradiation by radioactive materials. }\end{array}$} \\
\hline
\end{tabular}


Table A.3-2

Conceptual Site Model Description of Elements for Each CAS in CAU 556

(Page 4 of 4 )

\begin{tabular}{|c|c|c|c|c|}
\hline CAS Identifier & $06-20-04$ & $06-99-09$ & $25-60-03$ & $25-64-01$ \\
\hline CAS Description & $\begin{array}{c}\text { National Cementers } \\
\text { Dry Well }\end{array}$ & Birdwell Test Hole & $\begin{array}{c}\text { E-MAD Stormwater } \\
\text { Discharge and Piping }\end{array}$ & $\begin{array}{c}\text { Vehicle Washdown and } \\
\text { Drainage Pit }\end{array}$ \\
\hline
\end{tabular}

CAS $=$ Corrective action site

$\mathrm{COC}=$ Contaminant of concern

$\mathrm{COPC}=$ Contaminant of potential concern

$\mathrm{DRO}=$ Diesel-range organics

$\mathrm{E}-\mathrm{MAD}=$ Engine, Maintenance, Assembly, and Disassembly

$\mathrm{PCB}=$ Polychlorinated biphenyl

RCRA = Resource Conservation and Recovery Act

$\mathrm{TPH}=$ Total petroleum hydrocarbon 


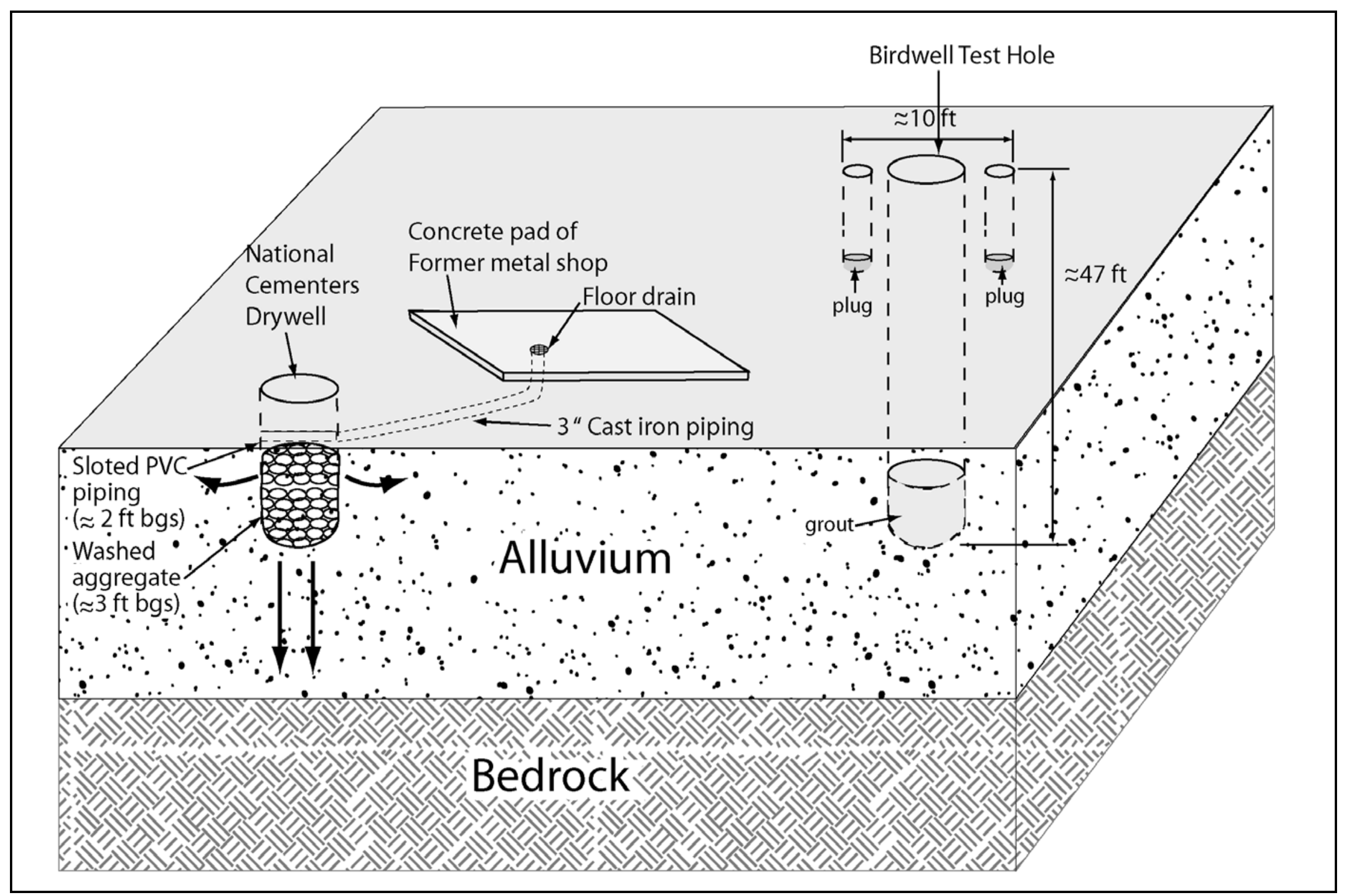

Figure A.3-1

Conceptual Site Model for CAS 06-20-04 and CAS 06-99-09 


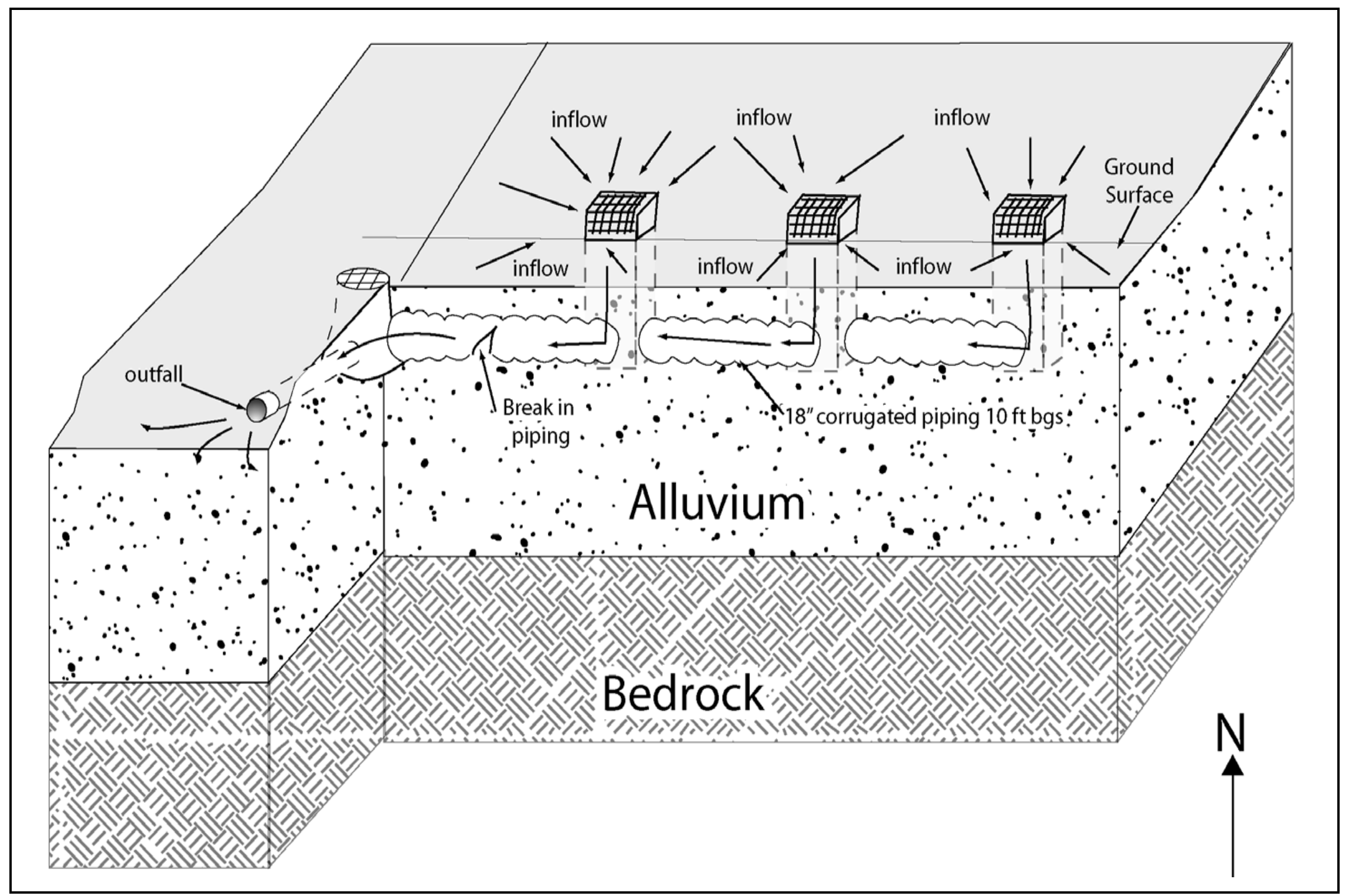

Figure A.3-2

Conceptual Site Model for CAS 25-60-03 


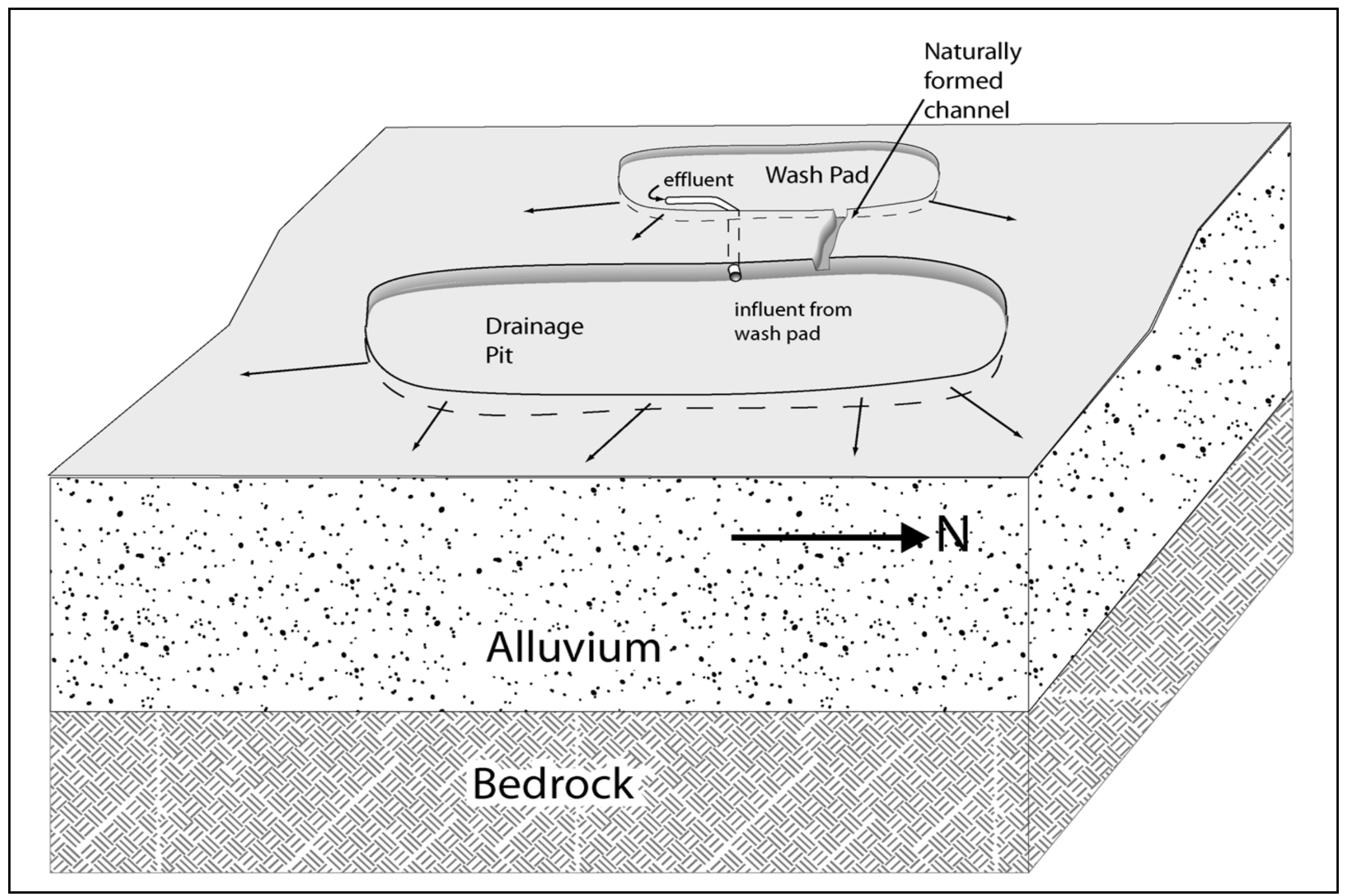

Figure A.3-3

Conceptual Site Model for CAS 25-64-01 


\section{A.3.2.2 Potential Contaminants}

The COPCs were identified during the planning process through the review of site history, process knowledge, personal interviews, past investigation efforts (where available), and inferred activities associated with the CASs. Because complete information regarding activities performed at the CAU 556 sites is not available, contaminants detected at similar NTS sites were included in the contaminant lists to reduce uncertainty. The list of COPCs is intended to encompass all of the contaminants that could potentially be present at each CAS. The COPCs applicable to Decision I environmental samples from each of the CASs of CAU 556 are defined as the constituents reported from the analytical methods stipulated in Table A.3-3.

During the review of site history documentation, process knowledge information, personal interviews, past investigation efforts (where available), and inferred activities associated with the CASs, some of the COPCs were identified as targeted contaminants at specific CASs. Targeted contaminants are those COPCs for which evidence in the available site and process information suggests that they may be reasonably suspected to be present at a given CAS. The targeted contaminants are required to meet a more stringent completeness criteria than other COPCs thus providing greater protection against a decision error (Section A.8.0). Targeted contaminants for each CAU 556 CAS are identified in Table A.3-4. 
Table A.3-3

Analytical Program ${ }^{a}$

(Includes Waste Characterization Analyses)

\begin{tabular}{|c|c|c|c|c|}
\hline Analyses & CAS 06-20-04 & CAS 06-99-09 & CAS 25-60-03 & CAS 25-64-01 \\
\hline \multicolumn{5}{|c|}{ Organic Contaminants of Potential Concern (COPCs) } \\
\hline $\begin{array}{l}\text { Total Petroleum Hydrocarbons- } \\
\text { Diesel-Range Organics }\end{array}$ & $\mathrm{X}$ & $\mathrm{X}$ & $\mathrm{x}$ & $x$ \\
\hline $\begin{array}{l}\text { Total Petroleum Hydrocarbons- } \\
\text { Gasoline-Range Organics }\end{array}$ & $\mathrm{X}$ & $\mathrm{X}$ & $\mathrm{X}$ & $\mathrm{X}$ \\
\hline Polychlorinated Biphenyls & $\mathrm{X}$ & & $\mathrm{X}$ & $\mathrm{X}$ \\
\hline Semivolatile Organic Compounds & $\mathrm{X}$ & $\mathrm{X}$ & $\mathrm{X}$ & $\mathrm{X}$ \\
\hline Volatile Organic Compounds & $\mathrm{X}$ & $\mathrm{X}$ & $\mathrm{X}$ & $\mathrm{X}$ \\
\hline \multicolumn{5}{|c|}{ Inorganic COPCs } \\
\hline $\begin{array}{c}\text { Resource Conservation and Recovery } \\
\text { Act Metals }\end{array}$ & $\mathrm{X}$ & $\mathrm{X}$ & $x$ & $\mathrm{x}$ \\
\hline Total Beryllium & $\mathrm{X}$ & $\mathrm{X}$ & $\mathrm{X}$ & $\mathrm{X}$ \\
\hline \multicolumn{5}{|c|}{ Radionuclide COPCs } \\
\hline Gamma Spectroscopy $^{0}$ & $\bar{X}$ & $\mathrm{X}$ & $\mathrm{X}$ & $\mathrm{X}$ \\
\hline Isotopic Uranium & $\mathrm{X}$ & $\mathrm{X}$ & $\mathrm{X}$ & $x$ \\
\hline Isotopic Plutonium & $\mathrm{X}$ & $\mathrm{X}$ & $\mathrm{X}$ & $x$ \\
\hline Strontium-90 & $\mathrm{X}$ & $\mathrm{X}$ & $\mathrm{X}$ & $x$ \\
\hline \multicolumn{5}{|c|}{ Waste Characterization Analyses } \\
\hline Gross Alpha/Beta & $\mathrm{X}$ & $\mathrm{X}$ & $\mathrm{X}$ & $\mathrm{X}$ \\
\hline Tritium & $\mathrm{X}$ & $\mathrm{X}$ & $\mathrm{X}$ & $\mathrm{X}$ \\
\hline
\end{tabular}

$X=$ Required analytical method

${ }^{a}$ The COPCs are the constituents reported from the analytical methods listed.

${ }^{\mathrm{b}}$ Results of gamma analysis will be used to determine whether further radioanalytical analysis is warranted. 
Table A.3-4

Targeted Contaminants for CAU 556

\begin{tabular}{|c|c|}
\hline $\begin{array}{c}\text { Corrective Action } \\
\text { Site }\end{array}$ & Targeted Contaminant(s) \\
\hline \hline $06-20-04$ & 1,1,1-trichloroethane, TPH-DRO \\
\hline $25-60-03$ & TPH-DRO, Cd, Pb, PCBs \\
\hline $25-64-01$ & TPH-DRO \\
\hline
\end{tabular}

$\mathrm{Cd}=$ Cadmium

$\mathrm{DRO}=$ Diesel-range organics

$\mathrm{Pb}=$ Lead

$\mathrm{PCB}=$ Polychlorinated biphenyl

$\mathrm{TPH}=$ Total petroleum hydrocarbons

\section{A.3.2.3 Contaminant Characteristics}

Contaminant characteristics include, but are not limited to: solubility, density, and adsorption potential. In general, contaminants with low solubility, high affinity for media, and high density can be expected to be found relatively close to release points. Contaminants with small particle size, high solubility, low density, and/or low affinity for media are found further from release points or in low areas where evaporation of ponding will concentrate dissolved contaminants.

\section{A.3.2.4 Site Characteristics}

Site characteristics are defined by the interaction of physical, topographical, and meteorological attributes and properties. Physical properties include permeability, porosity, hydraulic conductivity, degree of saturation, sorting, chemical composition, and organic content. Topographical and meteorological properties and attributes include slope stability, precipitation frequency and amounts, precipitation runoff pathways, drainage channels and ephemeral streams, and evapotranspiration potential.

\section{A.3.2.5 Migration Pathways and Transport Mechanisms}

Migration pathways include the lateral migration of potential contaminants across surface soils/sediments and vertical migration of potential contaminants through subsurface soils.

Lateral migration is minimal in the Area 6 CASs as it would only occur in the sub-surface and conform with vertical migration restrictions such as a layer of hardpan. This migration would end when the restrictive layer ends or there is a break in the layer through which contaminants could 
continue vertical migration. Lateral migration at CAS 25-60-03 is dominant as the system is designed for the lateral movement of water (and entrained contaminants) away from the E-MAD Complex. Lateral migration is enhanced with each heavy episode of rain entering the discharge system, especially at the outfall, where contaminants may be pushed further away from the discharge pipe with each episode. The contaminants would move laterally towards the southwest, as this is the general sloping of the Jackass Flats basin. No natural wash is located near the discharge point of the system, and the contaminants are expected to be contiguous to and relatively near the outfall.

Lateral migration at CAS 25-64-01 is primarily directed toward the drainage pit adjacent to the vehicle washdown pad. The size of the drainage pit has reasonably assumed to have contained contaminant lateral movement as the slope is gentle and southerly. Because the runoff from the washdown pad enters the drainage pit near the northern end of the drainage pit, lateral movement of contaminants is expected to end within the confines of the drainage pit.

Infiltration and percolation of precipitation serves as a driving force for downward migration of contaminants. However, due to high potential evapotranspiration (annual potential evapotranspiration at the Area 3 Radiological Waste Management Site has been estimated at 62.6 in. [Shott et al., 1997]) and limited precipitation for this region (3 to 8 in. annually [Winograd and Thordarson, 1975]), percolation of infiltrated precipitation at the NTS does not provide a significant mechanism for vertical migration of contaminants to groundwater (DOE/NV, 1992).

\section{A.3.2.6 Exposure Scenarios}

Human receptors may be exposed to COPCs through oral ingestion, inhalation, dermal contact (absorption) of surface soil or debris due to inadvertent disturbance of these materials or irradiation by radioactive materials. The land-use and exposure scenarios for the CAU 556 CASs are listed in Table A.3-5. These scenarios are based on NTS current and future land use. Because site personnel may periodically perform work at the areas near the CASs, they are considered to be occasional use areas. 
Table A.3-5

Land-Use and Exposure Scenarios

\begin{tabular}{|c|c|c|}
\hline $\begin{array}{l}\text { Corrective } \\
\text { Action Site }\end{array}$ & Record of Decision Land-Use Zone & Exposure Scenario \\
\hline $25-60-03$ & $\begin{array}{l}\text { Research Test and Experiment Zone } \\
\text { This area is designated for small-scale research and } \\
\text { development projects and demonstrations; pilot } \\
\text { projects; outdoor tests; and experiments for the } \\
\text { development, quality assurance, or reliability of } \\
\text { material and equipment under controlled conditions. } \\
\text { This zone includes compatible defense and } \\
\text { nondefense research, development, and testing } \\
\text { projects and activities. }\end{array}$ & $\begin{array}{c}\text { Remote Use Area } \\
\text { Worker will be exposed to the site regularly but } \\
\text { is not assigned to the site (equivalent to } \\
336 \text { hours per year for an entire career). } \\
\text { Provides sheltered work space. }\end{array}$ \\
\hline $25-64-01$ & $\begin{array}{l}\text { Research Test and Experiment Zone } \\
\text { This area is designated for small-scale research and } \\
\text { development projects and demonstrations; pilot } \\
\text { projects; outdoor tests; and experiments for the } \\
\text { development, quality assurance, or reliability of } \\
\text { material and equipment under controlled conditions. } \\
\text { This zone includes compatible defense and } \\
\text { nondefense research, development, and testing } \\
\text { projects and activities. }\end{array}$ & \multirow[t]{2}{*}{$\begin{array}{l}\text { Occasional Use Area } \\
\text { Worker will be exposed to the site occasionally } \\
\text { (up to } 80 \text { hours per year for } 5 \text { years). Site } \\
\text { structures are not present for shelter and } \\
\text { comfort of the worker. }\end{array}$} \\
\hline $\begin{array}{l}06-20-04 \\
06-99-09\end{array}$ & $\begin{array}{l}\text { Nuclear Test } \\
\text { This area is reserved for dynamic experiments, } \\
\text { hydrodynamic tests, and underground nuclear } \\
\text { weapons and weapons effects tests. This zone } \\
\text { includes compatible defense and nondefense } \\
\text { research, development, and testing activities. }\end{array}$ & \\
\hline
\end{tabular}




\section{A.4.0 Step 2 - Identify the Goal of the Study}

Step 2 of the DQO process states how environmental data will be used to meet objectives and solve the problem, identify study questions or decision statement(s), and consider alternative outcomes or actions that occur upon answering the question(s).

\section{A.4.1 Decision Statements}

The Decision I statement is: “Is any COC present in environmental media within the CAS?” For judgmental sampling design, analytical results for a COPC above the FAL will result in that COPC being designated as a COC. A COC may also be defined as a contaminant that, in combination with other like contaminants, is determined to jointly pose an unacceptable risk based on a multiple constituent analysis (NNSA/NSO, 2006). If a COC is detected, then Decision II must be resolved.

The Decision II statement is: "If a COC is present, is sufficient information available to evaluate potential corrective action alternatives?” Sufficient information is defined to include:

- Identifying the volume of media containing any COC bounded by analytical sample results in lateral and vertical directions.

- The information needed to evaluate the feasibility of remediation alternatives (bioassessment if natural attenuation or biodegradation is considered, and geotechnical data if construction or evaluation of barriers is considered).

A corrective action will be determined for any site containing a COC. The evaluation of the need for corrective action will include the present potential of wastes at a site that may cause future contamination of site environmental media if those wastes were to be released. To evaluate if potential source material could result in the introduction of a COC to the surrounding environmental media, the following conservative assumptions were made:

- That the system (e.g., discharge, well) would fail at some point and the contents would be released into the surrounding media during stormwater events.

- That the resulting concentration of contaminants in the surrounding media would be equal to the concentration of contaminants in the system. 
- That any contaminant in a liquid-containing system, exceeding the RCRA toxicity characteristic concentration, can result in COC introduction into the surrounding media.

Sediment within the catch basins and stormwater piping that contain a contaminant, exceeding an equivalent FAL concentration, would be considered to be potential source material and require a corrective action. Standing liquids within the catch basins and stormwater piping, or the wells in Area 6 with contaminant concentrations exceeding an equivalent toxicity characteristic action level, would be considered to be potential source material and require corrective action.

If sufficient information is not available to evaluate potential corrective action alternatives, then site conditions will be re-evaluated and additional samples collected (as long as the scope of the investigation is not exceeded and any CSM assumption has not been shown to be incorrect).

\section{A.4.2 Alternative Actions to the Decisions}

In this section the actions that may be taken to solve the problem are identified depending on the possible outcomes of the investigation.

\section{A.4.2.1 Alternative Actions to Decision I}

If no COC associated with a release from the CAS is detected, then no further assessment of the CAS is required. If a COC associated with a release from the CAS is detected, then the extent of COC contamination will be determined, and additional information required to evaluate potential corrective action alternatives will be collected.

\section{A.4.2.2 Alternative Actions to Decision II}

If sufficient information is available to evaluate potential corrective action alternatives, then no further assessment of the CAS is required. If sufficient information is not available to evaluate potential corrective action alternatives, then additional samples will be collected. 


\section{A.5.0 Step 3 - Identify Information Inputs}

Step 3 of the DQO process identifies the necessary information, determines information sources, and identifies sampling and analysis methods that will allow reliable comparisons with FALs.

\section{A.5.1 Information Needs}

To resolve Decision I (determine whether a COC is present at a given CAS), samples need to be collected and analyzed following these two criteria:

- Samples must be either (1) collected in areas most likely to contain a COC (judgmental sampling) or (2) properly represent contamination at the CAS (probabilistic sampling)

- The analytical suite selected must be sufficient to identify any COCs present in the samples.

To resolve Decision II (determine whether sufficient information is available to evaluate potential corrective action alternatives at each CAS), samples need to be collected and analyzed to meet the following criteria:

- Samples must be collected in areas contiguous to the contamination but where contaminant concentrations are below FALs.

- Samples of the waste or environmental media must provide sufficient information to determine potential remediation waste types.

- Samples of well liquid contents, if present, must provide sufficient RCRA toxicity information to determine if they contain potential source material.

- Appropriate samples must be submitted to evaluate the feasibility of remediation alternatives (e.g., bioassessment if natural attenuation or biodegradation is considered, and geotechnical data if construction or evaluation of barriers is considered).

- The analytical suites selected must be sufficient to detect contaminants at concentrations equal to or less than corresponding FALs.

\section{A.5.2 Sources of Information}

Information to satisfy Decision I and Decision II will be generated by collecting environmental samples using grab sampling, hand augering, direct push, backhoe excavation, or other appropriate 
sampling methods. These samples will be submitted to analytical laboratories meeting the quality criteria stipulated in the Industrial Sites QAPP (NNSA/NV, 2002a). Only validated data from analytical laboratories will be used to make DQO decisions. Sample collection and handling activities will follow standard procedures.

\section{A.5.2.1 Sample Locations}

The sampling approach design for the CAU 556 CASs must ensure that data collected are sufficient for selection of the corrective action alternatives (EPA, 2002). To meet this objective, the samples collected from each site should be from locations that most likely contain a COC, if present (judgmental), or properly represent any contamination at the CAS. These sample locations, therefore, can be selected by means of either (1) biasing factors used in judgmental sampling (e.g., a stain likely containing a spilled substance) or (2) a probabilistic sampling design. Because the information available to develop judgmental sampling is sufficient for the CAU 556 CASs, the judgmental sampling approach will be used for the CAI. A judgmental sampling design has been developed for the CAU 556 CASs due to the presence and significance of biasing factors.

Decision I sample locations at CASs 06-20-04, 25-60-03, and 25-64-01 will be determined based upon the possibility of the soil containing a COC, if present at the CAS. These locations will be selected based on field-screening techniques, biasing factors, the CSM, and existing information. Samples of the contents of the CAS 06-99-09 test well will define the potential for CAS 06-99-09 to contribute COCs to the surrounding media. Analytical suites for Decision I samples will include all COPCs identified in Table A.3-3.

Field-screening techniques may be used at all CASs except CAS 06-99-09 to select appropriate sampling locations by providing semiquantitative data that can be used to comparatively select samples to be submitted for laboratory analyses from several screening locations. Field screening may also be used for health and safety monitoring and to assist in making appropriate health and safety decisions. The following field-screening methods may be used to select analytical samples at CAU 556:

- Volatile organic compounds - A VOC detection instrument will be used to conduct headspace analysis, because VOCs are a common concern at the NTS and have not been ruled out based on process knowledge. 
- Walkover surface area radiological surveys - A radiological survey instrument will be used over approximately 100 percent of the CAS boundaries to detect localized areas of elevated radiological contamination, as permitted by terrain and field conditions. At CAS 25-60-03, the surveys will be limited to the outfall region.

- Alpha and beta/gamma radiation - A radiological survey instrument will be used at all CASs.

Biasing factors may also be used to select samples to be submitted for laboratory analyses based on existing site information and site conditions discovered during the investigation. The following factors will also be considered in selecting locations for analytical samples at CAU 556:

- Documented process knowledge on source and location of release (e.g., volume of release).

- Stains: A spot or area on the soil surface that may indicate the presence of a potentially hazardous liquid. Typically, stains indicate an organic liquid (e.g., an oil) has reached the soil, and may have spread vertically and horizontally.

- Elevated radiation: A location identified during radiological surveys that had alpha/beta/gamma levels significantly higher than surrounding background soil.

- Geophysical anomalies: A location identified during geophysical surveys that had results indicating surface or subsurface materials existed, and were not consistent with the natural surroundings (e.g., buried concrete or metal, surface metallic objects).

- Drums, containers, equipment or debris: Materials of interest that may have been used at, or added to, a location, and may have contained, or come in contact with, hazardous or radioactive substances at some point during use.

- Preselected areas based on process knowledge of the site: Locations for which evidence such as historical photographs, experience from previous investigations, or interviewee input, exists that a release of hazardous or radioactive substances may have occurred.

- Preselected areas based on process knowledge of the contaminant(s): Locations that reasonably may have received contamination, selected on the basis of the chemical and/or physical properties of the contaminant(s) in that environmental setting.

- Experience and data from investigations of similar sites.

- Presence of debris, waste, or equipment.

- Odor.

- Physical and chemical characteristics of contaminants. 
- Other biasing factors: Factors not defined previously for the CAI but that have become evident once the site investigation is under way.

Decision II sample step-out locations will be selected based on the CSM, biasing factors, and existing data. Analytical suites will include those parameters that exceeded FALs (i.e., COCs) in previous samples. Biasing factors to support Decision II sample locations include Decision I biasing factors plus available analytical results.

\section{A.5.2.2 Analytical Methods}

Analytical methods are available to provide the data needed to resolve the decision statements. The analytical methods and laboratory requirements (e.g., detection limits, precision, and accuracy) are provided in Tables 3-4 and 3-5. 


\section{A.6.0 Step 4 - Define the Boundaries of the Study}

Step 4 of the DQO process defines the target population of interest and its relevant spatial boundaries, specifies temporal and other practical constraints associated with sample/data collection, and defines the sampling units on which decisions or estimates will be made.

\section{A.6.1 Target Populations of Interest}

The population of interest to resolve Decision I ("Is any COC present in environmental media within the CAS?”) is any location within the site that is contaminated with any contaminant above a FAL (judgmental sampling). The populations of interest to resolve Decision II ("If a COC is present, is sufficient information available to evaluate potential corrective action alternatives?”) are:

- Each one of a set of locations bounding contamination in lateral and vertical directions.

- Potential remediation waste.

- Environmental media where natural attenuation or biodegradation or construction/evaluation of barriers is considered.

\section{A.6.2 Spatial Boundaries}

Spatial boundaries are the maximum lateral and vertical extent of expected contamination at each CAS as shown in Table A.6-1. Contamination found beyond these boundaries may indicate a flaw in the CSM and may require re-evaluation of the CSM before the investigation could continue. Each CAS is considered geographically independent and intrusive activities are not intended to extend into the boundaries of neighboring CASs.

\section{A.6.3 Practical Constraints}

Practical constraints such as military activities at the NTS, weather (i.e., high winds, rain, lightning, extreme heat), utilities, threatened or endangered animal and plants, unstable or steep terrain, and/or access restrictions may affect the ability to investigate this site. The practical constraints associated with the investigation of the CAU 556 CASs are summarized in Table A.6-2. 
Table A.6-1

Spatial Boundaries of CAU 556 CASs

\begin{tabular}{|c|l||}
\hline Corrective Action Site & \multicolumn{1}{|c|}{ Spatial Boundaries } \\
\hline \hline $06-20-04$ & $\begin{array}{l}\text { The footprint of the dry well and underground piping, plus a 20-ft lateral buffer } \\
\text { and 15 ft bgs vertically, unless hardpan is encountered }\end{array}$ \\
\hline $06-99-09$ & The well \\
\hline $25-60-03$ & $\begin{array}{l}\text { The footprint of the catch basins and manhole, the underground piping, plus a } \\
\text { 5-ft lateral buffer (except at the outfall, where a 100-ft lateral buffer will be } \\
\text { used), and 15 ft bgs vertically, unless hardpan is encountered }\end{array}$ \\
\hline $25-64-01$ & $\begin{array}{l}\text { The footprint of the vehicle washdown pad and the drainage pit, plus a 20 ft } \\
\text { lateral buffer around the vehicle washdown pad, and 10 ft bgs, unless hardpan } \\
\text { is encountered }\end{array}$ \\
\hline
\end{tabular}

bgs = Below ground surface

$\mathrm{ft}=$ Foot

Table A.6-2

Practical Constraints for the CAU 556 Field Investigation

\begin{tabular}{||c|l|}
\hline Corrective Action Site & \multicolumn{1}{|c|}{ Practical Constraints } \\
\hline \hline $06-20-04$ & $\begin{array}{l}\text { Weather (i.e., high winds, rain, lightning, extreme heat), concrete pad of former } \\
\text { metals shop, underground utilities }\end{array}$ \\
\hline $06-99-09$ & Weather (i.e., high winds, rain, lightning, extreme heat), underground utilities \\
\hline $25-60-03$ & $\begin{array}{l}\text { Weather (i.e., high winds, rain, lightning, extreme heat), access to catch } \\
\text { basins, access to manhole, access to underground piping between catch } \\
\text { basins and before outfall; site is still passively active; possible activities at } \\
\text { E-MAD; desert tortoise habitat }\end{array}$ \\
\hline $25-64-01$ & $\begin{array}{l}\text { Weather (i.e., high winds, rain, lightning, extreme heat), underground utilities; } \\
\text { possible activities in the area; desert tortoise habitat }{ }^{\mathrm{a}}\end{array}$ \\
\hline
\end{tabular}

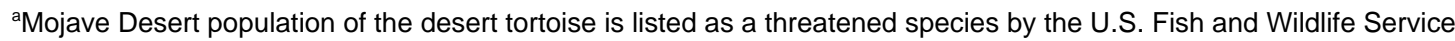
(DOE/NV, 1996).

bgs = Below ground surface

$\mathrm{E}-\mathrm{MAD}=$ Engine Maintenance, Assembly, and Disassembly

$\mathrm{ft}=$ Foot

\section{A.6.4 Define the Sampling Units}

The scale of decision-making in Decision I is defined as the CAS. Any COC detected at any location within the CAS will cause the determination that the CAS is contaminated and needs further evaluation. The scale of decision-making for Decision II is defined as a contiguous area contaminated with any COC originating from the CAS. Resolution of Decision II requires this contiguous area to be bounded laterally and vertically. 


\section{A.7.0 Step 5 - Develop the Analytic Approach}

Step 5 of the DQO process specifies appropriate population parameters for making decisions, defines action levels and generates an "If ... then ... else" decision rule that involves it.

\section{A.7.1 Population Parameters}

For judgmental sampling results, the population parameter is the observed concentration of each contaminant from each individual analytical sample. Each sample result will be compared to the FALs to determine the appropriate resolution to Decision I and Decision II. For Decision I, a single sample result for any contaminant exceeding a FAL would cause a determination that a COC is present within the CAS.

The Decision II population parameter is an individual analytical result from a bounding sample. For Decision II, a single bounding sample result for any contaminant exceeding a FAL would cause a determination that the contamination is not bounded.

\section{A.7.2 Action Levels}

The PALs presented in this section are to be used for site screening purposes. They are not intended to be used as cleanup action levels or FALs. However, they are useful in screening out contaminants that are not present in sufficient concentrations to warrant further evaluation and, therefore, streamline the consideration of remedial alternatives. The RBCA process used to establish FALs is described in the Industrial Sites Project Establishment of Final Action Levels (NNSA/NSO, 2006). This process conforms with Nevada Administrative Code (NAC) Section 445A.227, which lists the requirements for sites with soil contamination (NAC, 2006a). For the evaluation of corrective actions, NAC Section 445A.22705 (NAC, 2006b) requires the use of ASTM Method E 1739-95 (ASTM, 1995) to "conduct an evaluation of the site, based on the risk it poses to public health and the environment, to determine the necessary remediation standards (i.e., FALs) or to establish that corrective action is not necessary.” 
This RBCA process defines three tiers (or levels) of evaluation involving increasingly sophisticated analyses:

- Tier 1 - Sample results from source areas (highest concentrations) are compared to action levels based on generic (non-site-specific) conditions (i.e., the PALs established in the CAIP). The FALs may then be established as the Tier 1 action levels or the FALs may be calculated using a Tier 2 evaluation.

- Tier 2 - Conducted by calculating Tier 2 SSTLs using site-specific information as inputs to the same or similar methodology used to calculate Tier 1 action levels. The Tier 2 SSTLs are then compared to individual sample results from reasonable points of exposure (as opposed to the source areas as is done in Tier 1) on a point-by-point basis. Total TPH concentrations will not be used for risk-based decisions under Tier 2 or Tier 3. Rather, the individual chemicals of concern will be compared to the SSTLs.

- $\quad$ Tier 3 - Conducted by calculating Tier 3 SSTLs on the basis of more sophisticated risk analyses using methodologies described in Method E1739-95 that consider site-, pathway-, and receptor-specific parameters.

The comparison of laboratory results to FALs and the evaluation of potential corrective actions will be included in the investigation report. The FALs will be defined (along with the basis for definition) in the investigation report.

\section{A.7.2.1 Chemical PALs}

Except as noted herein, the chemical PALs are defined as the EPA Region 9 Risk-Based Preliminary Remediation Goals (PRGs) for chemical contaminants in industrial soils (EPA, 2004). Background concentrations for RCRA metals and zinc will be used instead of PRGs when natural background concentrations exceed the PRG, as is often the case with arsenic on the NTS. Background is considered the average concentration plus two standard deviations of the average concentration for sediment samples collected by the Nevada Bureau of Mines and Geology throughout the Nevada Test and Training Range (formerly the Nellis Air Force Range) (NBMG, 1998; Moore, 1999). For detected chemical COPCs without established PRGs, the protocol used by the EPA Region 9 in establishing PRGs (or similar) will be used to establish PALs. If used, this process will be documented in the investigation report. 


\section{A.7.2.2 Total Petroleum Hydrocarbon PALs}

The PAL for TPH is 100 ppm as listed in NAC 445A.2272 (NAC, 2006c).

\section{A.7.2.3 Radionuclide PALs}

The PALs for radiological contaminants (other than tritium) are based on the NCRP Report No. 129 Recommended Screening Limits for Construction, Commercial, Industrial Land-Use Scenarios (NCRP, 1999) scaled to 25 mrem/yr dose constraint (Murphy, 2004) and the generic guidelines for residual concentration of radionuclides in DOE Order 5400.5 (DOE, 1993). These PALs are based on the construction, commercial, and industrial land-use scenario provided in the guidance and are appropriate for the NTS based on future land-use scenarios as presented in Section A.3.2. The PAL for tritium is based on the UGTA Project limit of 400,000 pCi/L for discharge of water containing tritium (NNSA/NV, 2002b).

Solid media such as concrete and/or structures may pose a potential radiological exposure risk to site workers if contaminated. The radiological PAL for solid media will be defined as the unrestricted-release criteria defined in the NV/YMP Radcon Manual (NNSA/NSO, 2004).

\section{A.7.3 Decision Rules}

The decision rules applicable to both Decision I and Decision II are:

- If COC contamination is inconsistent with the CSM or extends beyond the spatial boundaries identified in Section A.6.2, then work will be suspended and the investigation strategy reconsidered; otherwise, continue sampling to define the extent.

The decision rules for Decision I are:

- If the population parameter of any COPC in the Decision I population of interest (defined in Step 4) exceeds the corresponding FAL, then that contaminant is identified as a COC, and Decision II samples will be collected; otherwise, no further investigation is needed for that $\mathrm{COPC}$ in that population.

- If a COC exists at any CAS then a corrective action will be determined; otherwise, no further action will be necessary. 
- If a waste is present that, if released, has the potential to cause the future contamination of site environmental media, then a corrective action will be determined; otherwise, no further action will be necessary.

The decision rules for Decision II are:

- If the population parameter (the observed concentration of any COC) in the Decision II population of interest (defined in Step 4) exceeds the corresponding FAL in any bounding direction, then additional samples will be collected to complete the Decision II evaluation; otherwise, the extent of the COC contamination has been defined.

- If valid analytical results are available for the waste characterization samples defined in Section A.9.0, then the decision will be that sufficient information exists to characterize the IDW for disposal, determine potential remediation waste types, and evaluate the feasibility of remediation alternatives; otherwise, collect additional waste characterization samples. 


\section{A.8.0 Step 6 - Specify Performance or Acceptance Criteria}

Step 6 of the DQO process defines the decision hypotheses, specifies controls against false rejection and false acceptance decision errors, examines consequences of making incorrect decisions from the test, and places acceptable limits on the likelihood of making decision errors.

\section{A.8.1 Decision Hypotheses}

The baseline condition (i.e., null hypothesis) and alternative condition for Decision I are:

- $\quad$ Baseline condition - A COC is present.

- Alternative condition - A COC is not present.

The baseline condition (i.e., null hypothesis) and alternative condition for Decision II are as follows:

- Baseline condition - The extent of a COC has not been defined.

- Alternative condition - The extent of a COC has been defined.

Decisions and/or criteria have false negative or false positive errors associated with their determination. The impact of these decision errors and the methods that will be used to control these errors are discussed in the following subsections. In general terms, confidence in DQO decisions based on judgmental sampling results will be established qualitatively by:

- The development of and concurrence of CSMs (based on process knowledge) by stakeholder participants during the DQO process.

- Testing the validity of conceptual site models based on investigation results.

- Evaluating the quality of the data based on DQI parameters.

\section{A.8.2 False Negative Decision Error}

The false negative decision error would mean deciding that a COC is not present when it actually is (Decision I), or deciding that the extent of a COC has been defined when it has not (Decision II). In both cases, the potential consequence is an increased risk to human health and environment. 
In judgmental sampling, the selection of the number and location of samples is based on knowledge of the feature or condition under investigation and on professional judgment (EPA, 2002).

Judgmental sampling conclusions about the target population depend upon the validity and accuracy of professional judgment.

The false negative decision error (where consequences are more severe) for judgmental sampling designs is controlled by meeting these criteria:

- For Decision I, having a high degree of confidence that the sample locations selected will identify COCs if present anywhere within the CAS. For Decision II, having a high degree of confidence that the sample locations selected will identify the extent of COCs.

- Having a high degree of confidence that analyses conducted will be sufficient to detect any COCs present in the samples.

- Having a high degree of confidence that the dataset is of sufficient quality and completeness.

To satisfy the first criterion, Decision I samples must be collected in areas most likely to be contaminated by COCs. Decision II samples must be collected in areas that represent the lateral and vertical extent of contamination (above FALs). The following characteristics must be considered to control decision errors for the first criterion:

- Source and location of release

- Chemical nature and fate properties

- $\quad$ Physical transport pathways and properties

- Hydrologic drivers

These characteristics were considered during the development of the CSMs and selection of sampling locations. The field-screening methods and biasing factors listed in Section A.5.2.1 will be used to further ensure that appropriate sampling locations are selected to meet these criteria. Radiological survey instruments and field-screening equipment will be calibrated and checked in accordance with the manufacturer's instructions and approved procedures. The investigation report will present an assessment on the DQI of representativeness that samples were collected from those locations that best represent the populations of interest as defined in Section A.6.1.

To satisfy the second criterion, Decision I samples will be analyzed for the chemical and radiological parameters listed in Section 3.2. Decision II samples will be analyzed for those chemical and 
radiological parameters that identified unbounded COCs. The DQI of sensitivity will be assessed for all analytical results to ensure that all sample analyses had measurement sensitivities (detection limits) that were less than or equal to the corresponding FALs. If this criterion is not achieved, the affected data will be assessed (for usability and potential impacts on meeting site characterization objectives) in the investigation report.

To satisfy the third criterion, the entire dataset and individual sample results, will be assessed against the DQIs of precision, accuracy, comparability, and completeness as defined in the Industrial Sites QAPP (NNSA/NV, 2002a) and in Section 6.2.2. The DQIs of precision and accuracy will be used to assess overall analytical method performance as well as to assess the need to potentially "flag" (qualify) individual contaminant results when corresponding QC sample results are not within the established control limits for precision and accuracy. Data qualified as estimated for reasons of precision or accuracy may be considered to meet the constituent performance criteria based on an assessment of the data. The DQI for completeness will be assessed to ensure that all data needs identified in the DQO have been met. The DQI of comparability will be assessed to ensure that all analytical methods used are equivalent to standard EPA methods so that results will be comparable to regulatory action levels that have been established using those procedures. Strict adherence to established procedures and QA/QC protocol protects against false negatives. Site-specific DQIs are discussed in more detail in Section 6.2.2.

To provide information for the assessment of the DQIs of precision and accuracy, the following QC samples will be collected as required by the Industrial Sites QAPP (NNSA/NV, 2002a):

- Field duplicates (minimum of 1 per matrix per 20 environmental samples)

- Laboratory QC samples (minimum of 1 per matrix per 20 environmental samples or 1 per CAS per matrix, if less than 20 collected)

\section{A.8.3 False Positive Decision Error}

The false positive decision error would mean deciding that a COC is present when it is not, or a COC is unbounded when it is not, resulting in increased costs for unnecessary sampling and analysis.

False positive results are typically attributed to laboratory and/or sampling/handling errors that could cause cross contamination. To control against cross contamination, decontamination of sampling 
equipment will be conducted according to established and approved procedures and only clean sample containers will be used. To determine whether a false positive analytical result may have occurred, the following QC samples will be collected as required by the Industrial Sites QAPP (NNSA/NV, 2002a):

- Trip blanks (1 per sample cooler containing VOC environmental samples)

- Equipment blanks (1 per sampling event for each type of decontamination procedure)

- Source blanks (1 per uncharacterized source lot per sampling event)

- Field blanks (minimum of 1 per CAS, additional if field conditions change) 


\section{A.9.0 Step 7 - Develop the Plan for Obtaining Data}

Step 7 of the DQO process selects and documents a design that yields data that will best achieve performance or acceptance criteria. A judgmental sampling scheme will be implemented to select sample locations and evaluate analytical results for CAU 556. Sections A.9.1 through A.9.2 contain general information about collecting Decision I and Decision II samples under the judgmental sampling design, while the subsequent sections provide CAS-specific sampling activities, including proposed sample locations.

\section{A.9.1 Decision I Sampling}

A judgmental sampling design will be implemented for all of the CASs in CAU 556. Because individual sample results, rather than an average concentration, will be used to compare to FALs at the CASs undergoing judgmental sampling, statistical methods to generate site characteristics will not be used. Adequate representativeness of the entire target population may not be a requirement to development of a sampling design. If good previous information is available on the target site of interest, then the sampling may be designed to collect samples only from areas known to have the highest concentration levels on the target site. If the observed concentrations from these samples are below the action level, then a decision can be made that the site contains safe levels of the contaminant without the samples being truly representative of the entire area. (EPA, 2006)

All sample locations will be selected to satisfy the DQI of representativeness in that samples collected from selected locations will best represent the populations of interest as defined in Section A.6.1. To meet this criterion for judgmentally sampled sites, a biased sampling strategy will be used for Decision I samples to target areas with the highest potential for contamination, if it is present anywhere in the CAS. Sample locations will be determined based on process knowledge, previously acquired data, or the field-screening and biasing factors listed in Section A.5.2.1. If biasing factors are present in soils below locations where Decision I samples were removed, additional Decision I soil samples will be collected at depth intervals selected by the Site Supervisor based on biasing factors to a depth where the biasing factors are no longer present. The Site Supervisor has the discretion to modify the judgmental sample locations, but only if the modified locations meet the decision needs and criteria stipulated in this DQO. 


\section{A.9.2 Decision II Sampling}

To meet the DQI of representativeness for Decision II samples (that Decision II sample locations represent the population of interest as defined in Section A.6.1), judgmental sampling locations at each CAS will be selected based on the outer boundary sample locations where COCs were detected, the CSM, and other field-screening and biasing factors listed in Section A.5.2. In general, sample locations will be arranged in a triangular pattern around the Decision I location or area at distances based on site conditions, process knowledge, and biasing factors. If COCs extend beyond the initial step-outs, Decision II samples will be collected from incremental step-outs. Initial step-outs will be at least as deep as the vertical extent of contamination defined at the Decision I location and the depth of the incremental step-outs will be based on the deepest contamination observed at all locations. A clean sample (i.e., COCs less than FALs) collected from each step-out direction (lateral or vertical) will define extent of contamination in that direction. The number, location, and spacing of step-outs may be modified by the Site Supervisor as warranted by site conditions.

\section{A.9.3 Corrective Action Site 06-20-04, National Cementers Dry Well}

This section discusses the sampling and analysis design for CAS 06-20-04, National Cementers Dry Well, located at Area 6 of the NTS.

During Decision I sampling, soil samples will be collected from various depths from within and below the dry well. Subsurface samples will be collected from the side of the well where the drain line from the metals shop enters the well. Additional samples will be collected from the wall of the opposite side of the dry well from this location. Samples will be collected at the dry well/native soil interface, and at least one additional sample will be collected beneath these samples from within the underlying native material.

Proposed Decision I sampling locations at CAS 06-20-04 are shown in Figure A.9-1.

As discussed in Section A.2.0, surface radiological soil contamination at this site originating from nuclear testing is specifically excluded from this investigation.

Samples will be collected beneath the location where the cast iron pipe from the National Cementers metals shop connects to the horizontally oriented, perforated PVC pipe. During Decision I sampling, 


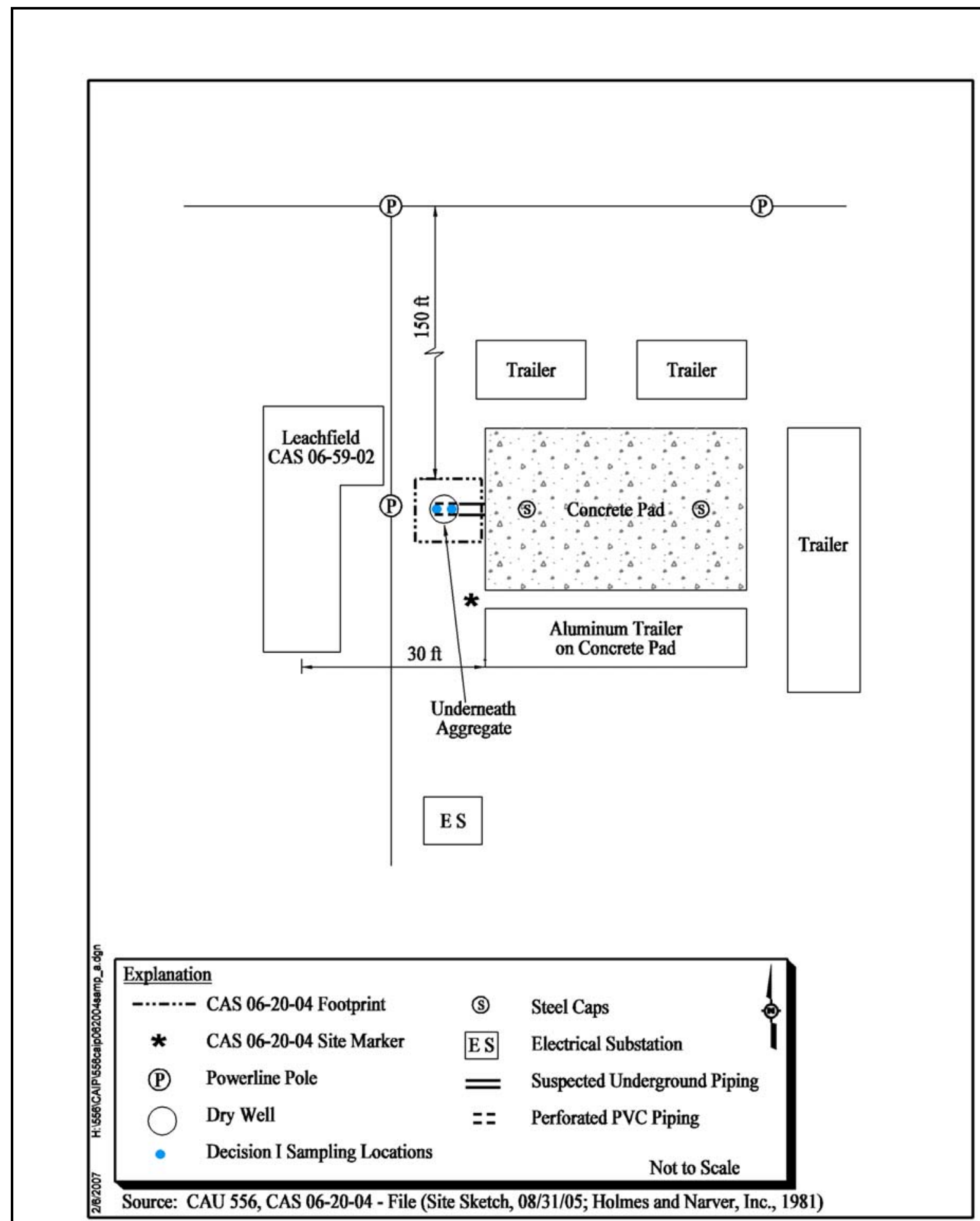

Figure A.9-1

Proposed Sample Locations at CAS 06-20-04 
a minimum of six samples will be collected from the dry well and the native soil beneath the dry well. Figure A.9-1 shows the proposed Decision I sample locations. Biasing factors will aid in the selection of soil to be collected.

\section{A.9.4 CAS 06-99-09, Birdwell Test Hole}

This section discusses the sampling and analysis design for CAS 06-99-09, Birdwell Test Hole, located at Area 6 of the NTS.

Corrective Action Site 06-99-09 consists of three wells constructed to be watertight for the testing of monitoring equipment used for downhole investigations. Process knowledge indicates that the only additions to the three test holes was water, with an occasional addition of liquid detergent to enhance signal transmission when simulating downhole investigations. The Birdwell Test Hole contains liquid that is presumed to be water. A sample of the liquid will be collected using a Composite Liquid Waste Sampler and analyzed for all the parameters listed in Table A.3-3. If sludge is present at the base of the well, a sample of it will be collected and analyzed for all the parameters listed in Table A.3-3. If liquid is in the two outer test holes, this will also be sampled in the same manner and analyzed, as well as any sludge that may be present. No soil sampling is proposed at this CAS.

Proposed Decision I sample locations are shown in Figure A.9-2. 


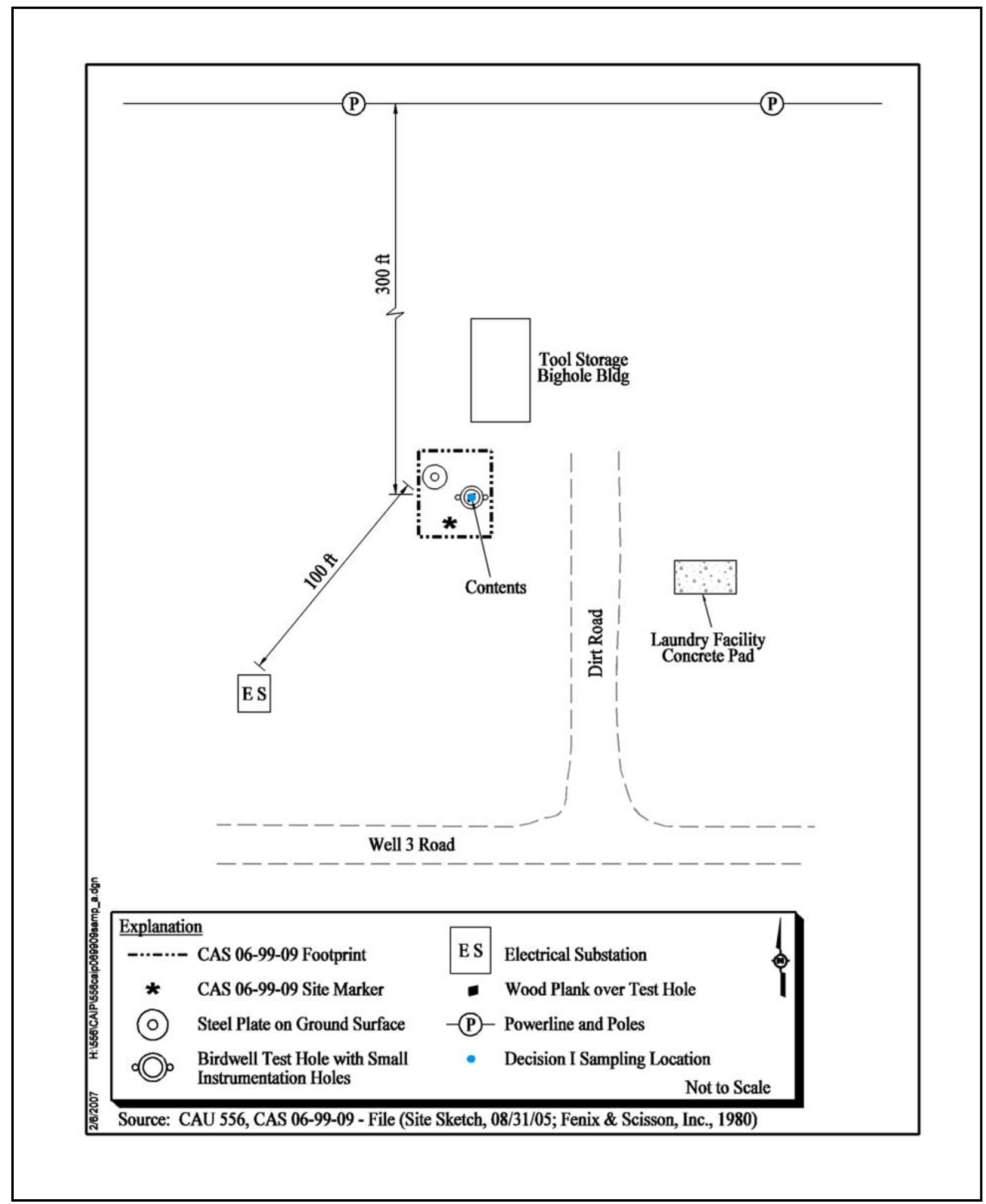

Figure A.9-2

Proposed Sample Locations at CAS 06-99-09 


\section{A.9.5 Corrective Action Site 25-60-03, E-MAD Stormwater Discharge and Piping}

This section discusses the sampling and analysis design for CAS 25-60-03, E-MAD Stormwater Discharge and Piping, located at Area 25 of the NTS.

Corrective action site 25-60-03 consists of three catch basins, a manhole, and an 18-in. diameter corrugated metal pipe that is approximately $10 \mathrm{ft}$ bgs. Each catch basin contains discolored soil/sediment at the bottom, and there is discolored soil located within the end of the pipe at the outfall and in the soil around the outfall. A minimum of 11 samples are planned to be collected from this CAS as follows:

- One sample from each of the three catch basins, if sufficient material is available

- One sample from within the manhole, if sufficient material is available

- Six samples from the outfall, one at 0 to $0.5 \mathrm{ft}$ bgs and the second at 1 to $1.5 \mathrm{ft}$ bgs, at each of three locations

- One sample from within the end of the outfall pipe, if sufficient material is available.

Depending on the site conditions, trenching along the sides of the catch basins may also be performed to ensure no contamination has occurred from possible breaks in the concrete construction of the catch basin.

Proposed Decision I sample locations are shown in Figure A.9-3. 


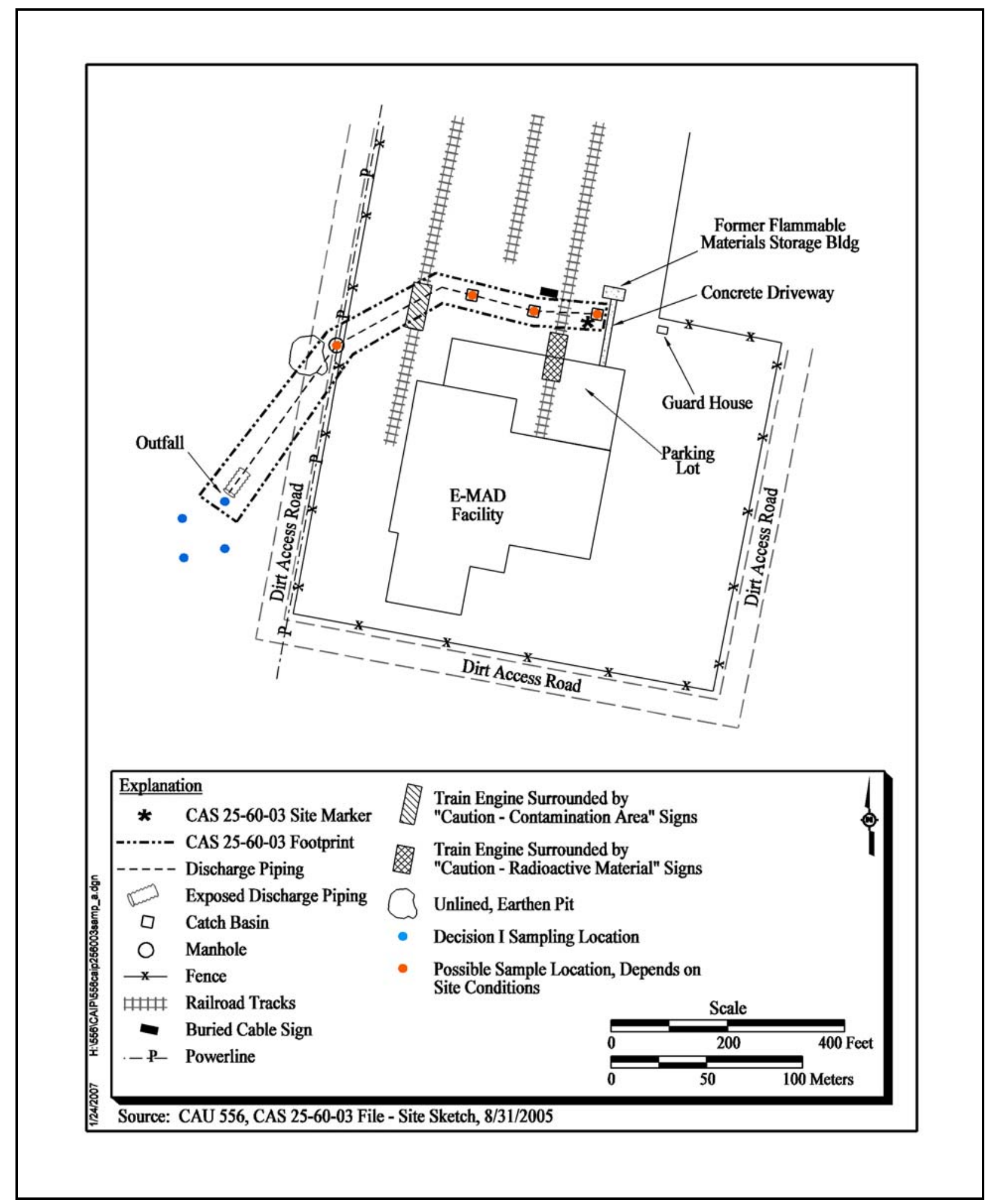

Figure A.9-3

Proposed Sample Locations at CAS 25-60-03 


\section{A.9.6 Corrective Action Site 25-64-01, Vehicle Washdown and Drainage Pit}

This section discusses the sampling and analysis design for CAS 25-64-01, Vehicle Washdown and Drainage Pit, located at Area 25 of the NTS.

Process knowledge and the locations of specific features within this CAS provide a sound basis for the identification of biased sample locations. A minimum of 10 soil samples will be collected at CAS 25-60-03. Three locations from within the area identified as the vehicle washdown pad will be sampled at both the leachrock/native soil interface and at approximately $1 \mathrm{ft}$ below the interface. Locations will be selected based on discolorations and/or depressions within the washdown pad or other locations reasonably expected to have COCs. Surface and subsurface samples will also be collected at the locations where effluent from the vehicle washdown pad first enters the drainage pit. One sample location is at the base of a 2-in. diameter pipe that connects the washdown pad to the drainage pit. A 2005 geophysical survey shows that the pipe extending into the vehicle washdown area and into the drainage pit are connected. The second sample location within the drainage pit is at the base of a naturally formed channel that runs between the vehicle washdown pad and the drainage pit that is located just to the north of the pipe. Although the time at which this channel was formed is uncertain, it will be assumed for the purpose of this investigation that it was formed when the vehicle washdown pad and drainage pit were in use. Surface and subsurface samples will be collected from both of these locations.

Proposed Decision I sample locations are shown in Figure A.9-4. 


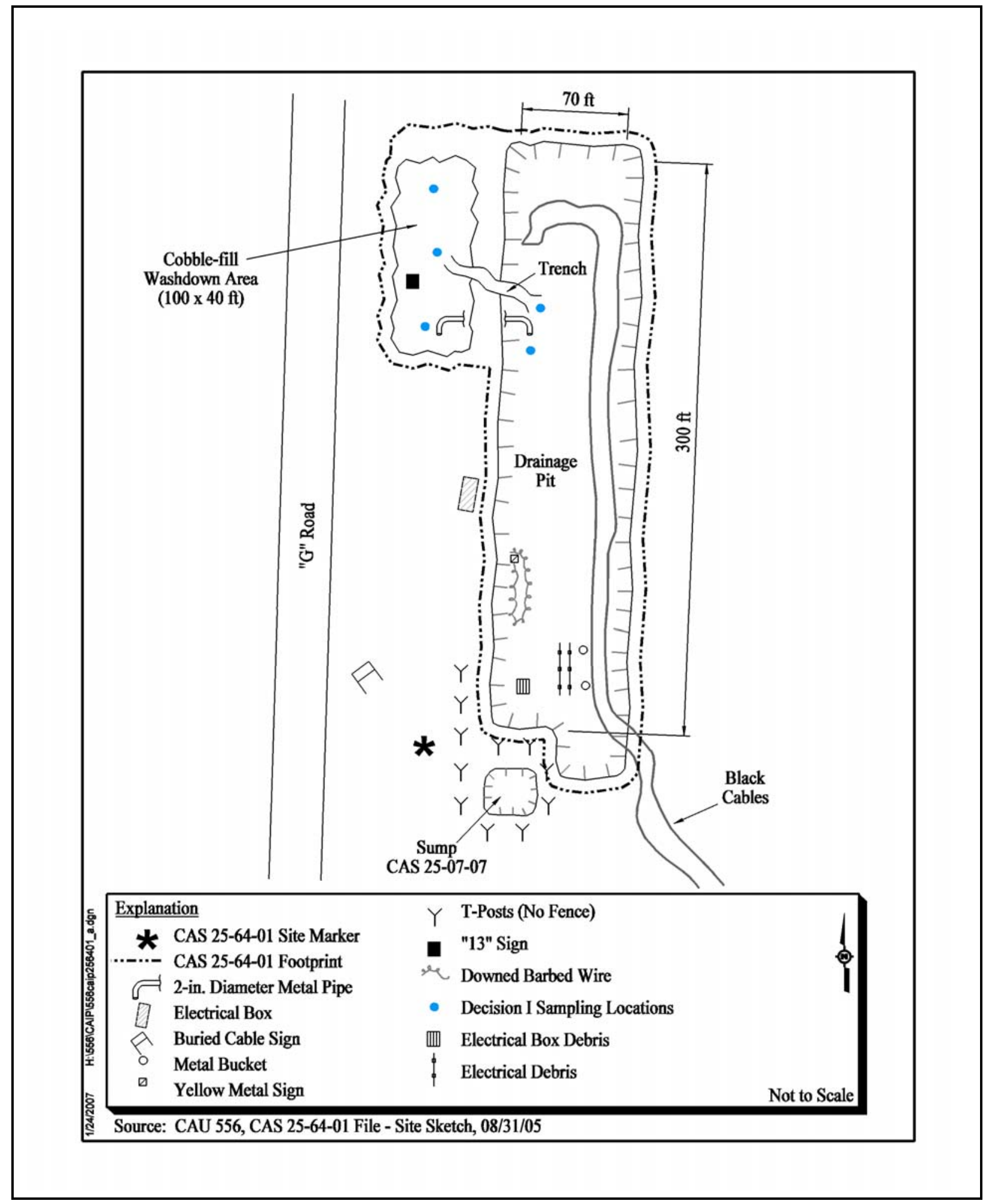

Figure A.9-4

Proposed Sample Locations at CAS 25-64-01 


\section{A.10.0 References}

ASTM, see American Society for Testing and Materials.

American Society for Testing and Materials. 1995. Standard Guide for Risk-Based Corrective Action Applied at Petroleum Release Sites, ASTM E 1739-95 (Reapproved 2002). Philadelphia, PA.

DOE, see U.S. Department of Energy.

DOE/NV, see U.S. Department of Energy, Nevada Operations Office.

EPA, see U.S. Environmental Protection Agency.

Fenix and Scisson, Inc. 1980. Engineering Drawing entitled, "Well 3-Batch Plant and Birdwell Yards.” October 1980. Fenix and Scisson Engineers and Contractors, Mercury, NV.

Holmes and Narver, Inc. 1981. Engineering Drawing of Area b Well 3 Yard entitled, "Birdwell and National Cement Facilities Water and Sewer System, Plot Plan Section and Detail.” Las Vegas, NV.

Moore, J., Science Applications International Corporation. 1999. Memorandum to M Todd (SAIC) entitled, “Background Concentrations for NTS and TTR Soil Samples,” 3 February. Las Vegas, NV: IT Corporation.

Murphy, T., Bureau of Federal Facilities. 2004. Letter to R. Bangerter (NNSA/NSO) entitled, "Review of Industrial Sites Project Document Guidance for Calculating Industrial Sites Project Remediation Goals for Radionuclides in Soil Using the Residual Radiation (RESRAD) Computer Code.” 19 November. Las Vegas, NV.

NAC, see Nevada Administrative Code.

NBMG, see Nevada Bureau of Mines and Geology.

NCRP, see National Council on Radiation Protection and Measurements.

National Council on Radiation Protection and Measurements. 1999. Recommended Screening Limits for Contaminated Surface Soil and Review of Factors Relevant to Site-Specific Studies, NCRP Report No. 129. Bethesda, MD.

Nevada Administrative Code. 2006a. NAC 445A.227, “Contamination of Soil: Order by Director for Corrective Action; Factors To Be Considered in Determining Whether Corrective Action Required.” Carson City, NV. As accessed at http://www.leg.state.nv.us/nac on 27 November. 
Nevada Administrative Code. 2006b. NAC 445A.22705, "Contamination of Soil: Evaluation of Site by Owner or Operator; Review of Evaluation by Division.” Carson City, NV. As accessed at http://www.leg.state.nv.us/nac on 27 November.

Nevada Administrative Code. 2006c. NAC 445A.2272, "Contamination of Soil: Establishment of Action Levels.” Carson City, NV. As accessed at http://www.leg.state.nv.us/nac on 27 November.

Nevada Bureau of Mines and Geology. 1998. Mineral and Energy Resource Assessment of the Nellis Air Force Range, Open-File Report 98-1. Reno, NV.

NNSA/NV, see U.S. Department of Energy, National Nuclear Security Administration Nevada Operations Office.

SNJV GIS Systems, see Stoller-Navarro Joint Venture Geographic Information Systems.

Shott, G.J., V. Yucel, M.J. Sully, L.E. Barker, S.E. Rawlinson, and B.A. Moore. 1997. Performance Assessment/Composite Analysis for the Area 3 Radioactive Waste Management Site at the Nevada Test Site, Nye County, Nevada, Rev. 2.0. Las Vegas, NV.

Stoller-Navarro Joint Venture Geographic Information Systems. 2007. ESRI ArcGIS Software.

U.S. Department of Energy. 1993. Radiation Protection of the Public and the Environment, DOE Order 5400.5, Change 2. Washington, DC: U.S. Government Printing Office.

U.S. Department of Energy, Nevada Operations Office. 1992. Remedial Investigation and Feasibility Study for the Plutonium Contaminated Soils at Nevada Test Site, Nellis Air Force Range and Tonopah Test Range, April. Las Vegas, NV.

U.S. Department of Energy, Nevada Operations Office. 1996. Final Environmental Impact Statement for the Nevada Test Site and Off-Site Locations in the State of Nevada, DOE/EIS 0243. Las Vegas, NV.

U.S. Department of Energy, National Nuclear Security Administration Nevada Operations Office. 2002a. Industrial Sites Quality Assurance Project Plan, Nevada Test Site, Nevada, Rev. 3, DOE/NV--372. Las Vegas, NV.

U.S. Department of Energy, National Nuclear Security Administration Nevada Operations Office. 2002b. Underground Test Area Project Waste Management Plan, DOE/NV--343-Rev. 2. Las Vegas, NV.

U.S. Department of Energy, National Nuclear Security Administration Nevada Site Office. 2004. NV/YMP Radiological Control Manual, Rev. 5, DOE/NV/11718--079, UC-702. Prepared by Bechtel Nevada. Las Vegas, NV. 
U.S. Department of Energy, National Nuclear Security Administration Nevada Site Office. 2006. Industrial Sites Project Establishment of Final Action Levels, DOE/NV--1107, Rev. 0. Las Vegas, NV.

U.S. Environmental Protection Agency. 2002. Guidance for Quality Assurance Project Plans, EPA QA/G5. Washington, DC.

U.S. Environmental Protection Agency. 2004. Region 9 Preliminary Remediation Goals (PRGs). As accessed at http://www.epa.gov/region09/waste/sfund/prg/index.htm on 27 November 2006. Prepared by S.J. Smucker. San Francisco, CA.

U.S. Environmental Protection Agency. 2006. EPA Guidance on Systematic Planning using the Data Quality Objectives Process, EPA QA/G-4. Washington, DC.

Winograd, I.J., and W. Thordarson. 1975. Hydrology and Hydrochemical Framework, South-Central Great Basin, Nevada-California, with Special Reference to the Nevada Test Site, USGS Professional Paper 712-C. Denver, CO. 
Appendix B

Project Organization

UNCONTROLLED when Printed 


\section{B.1.0 Project Organization}

The NNSA/NSO Acting Federal Sub-Project Director for the Industrial Sites Project is Peter Sanders, who can be contacted at (702) 295-1037. The NNSA/NSO Task Manager is also Peter Sanders.

The identification of the project Health and Safety Officer and the Quality Assurance Officer can be found in the appropriate plan. However, personnel are subject to change and it is suggested that the appropriate DOE Environmental Restoration Federal Project Director be contacted for further information. The Task Manager will be identified in the FFACO Monthly Activity Report before the start of field activities. 


\section{Appendix C}

\section{Nevada Division of Environmental Protection Comments}

(1 Page) 


\section{STATE OF NEVADA}

Department of Conservation \& Natural Resources

DIVISION OF ENVIRONMENTAL PROTECTION
Jim Gibbons, Governor Allen Biaggi, Director

January 4, 2007

Wilhelm R. Wilborn

Acting Environmental Restoration Federal Project Director

Environmental Restoration Project

National Nuclear Security Administration

Nevada Site Office

P. O. Box 98518

Las Vegas, NV 89193-8518

RE: Review of the draft Corrective Action Investigation Plan (CAIP) Corrective Action Unit (CAU) 556: Dry Wells and Surface Release Points Federal Facility Agreement and Consent Order

Dear Mr. Wilborn:

The Nevada Division of Environmental Protection, Bureau of Federal Facilities (NDEP) staff has received and reviewed the draft Corrective Action Investigation Plan (CAIP) for Corrective Action Unit (CAU) 556: Dry Wells and Surface Release Points. NDEP's review of this document did not indicate any deficiencies.

Note that the NDEP Permit Number for a Hazardous Waste Management Facility, as issued in 2005 , is NEV HW0021.

Address any questions regarding this matter to either Ted Zaferatos at (702) $486-2850$, ext. 234 , or to me at (702) 486-2850, ext. 229.

Sincerely,

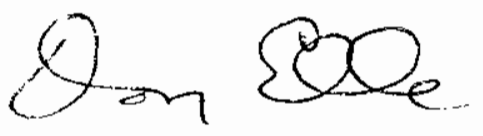

Don Elle, Ph.D.

Supervisor

Bureau of Federal Facilities

TZ 


\section{Library Distribution List}

\section{$\underline{\text { Copies }}$}

U.S. Department of Energy

National Nuclear Security Administration

Nevada Site Office

Technical Library

P.O. Box 98518, M/S 505

Las Vegas, NV 89193-8518

U.S. Department of Energy

Office of Scientific and Technical Information

P.O. Box 62

Oak Ridge, TN 37831-0062

Southern Nevada Public Reading Facility

c/o Nuclear Testing Archive

P.O. Box 98521, M/S 400

Las Vegas, NV 89193-8521

Manager, Northern Nevada FFACO

Public Reading Facility

c/o Nevada State Library \& Archives

100 N Stewart Street

Carson City, NV 89701-4285
1 (Uncontrolled, electronic copy)

1 (Uncontrolled, electronic copy)

2 (Uncontrolled, electronic copies)

1 (Uncontrolled, electronic copy) 